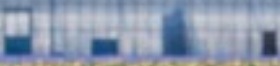

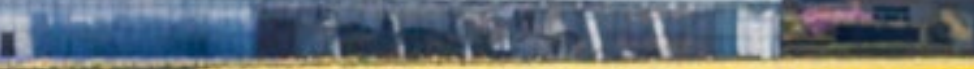

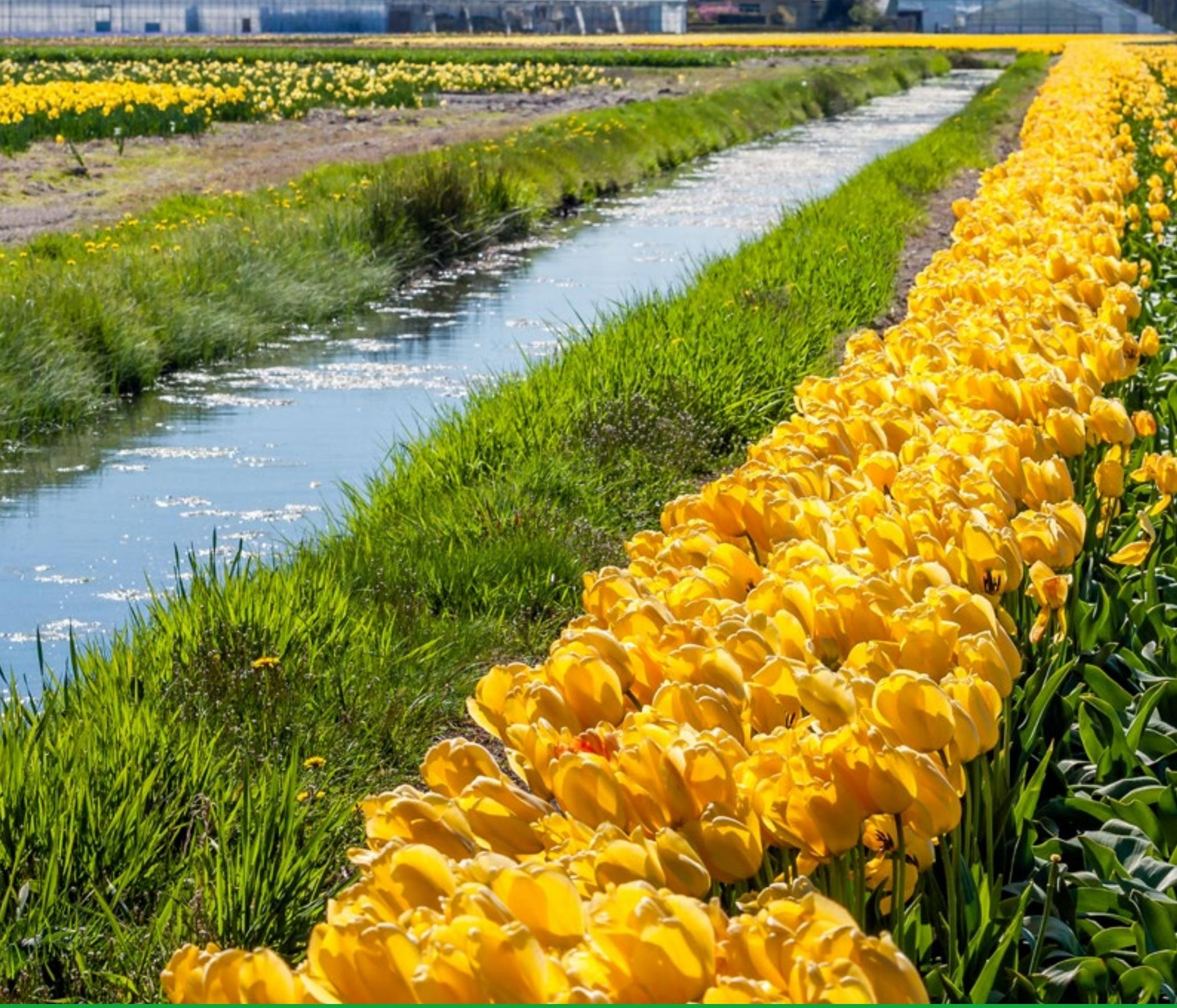

\title{
The TOXSWA model version 3.3 for pesticide behaviour in small surface waters
}

Description of processes 

The TOXSWA model version $\mathbf{3 . 3}$ for pesticide behaviour in small surface waters 
This WOt-technical report was produced in accordance with the Quality Manual of the Statutory Research Tasks Unit for Nature \& the Environment.

The mission of WOT Natuur \& Milieu is to carry out statutory research tasks on issues relating to nature and the environment. These tasks are implemented in order to support the Dutch Minister of Economic Affairs, who is responsible for these issues. The Statutory Research Tasks Unit for Nature and the Environment (WOT Natuur \& Milieu) works on products of the PBL Netherlands Environmental Assessment Agency, such as the Assessment of the Human Environment reports and the Nature Outlook reports. In addition, the unit advises the Ministry of Economic Affairs about fertilisers and pesticides and their authorisation, and provides data required to compile biodiversity reports to the European Union.

The 'WOt-technical reports' series presents the findings of research projects implemented for the Statutory Research Tasks Unit for Nature \& the Environment by various centres of expertise.

WOt-technical report 84 presents the findings of a research project commissioned and funded by the Dutch Ministry of Economic Affairs (EZ). 


\section{The TOXSWA model version 3.3 for pesticide behaviour in small surface waters}

Description of processes

M.M.S. ter Horst, W.H.J. Beltman \& F. van den Berg

ISSN 2352-2739

DOI: $10.18174 / 401504$ 


\begin{abstract}
Horst, M.M.S. ter, W.H.J. Beltman \& F. van den Berg (2016). The TOXSWA model version 3.3 for pesticide behaviour in small surface waters; Description of processes. Statutory Research Tasks Unit for Nature \& the Environment (WOT Natuur \& Milieu), WOt-technical report 84. 72 p.; 17 Figs; 1 Tabs; 42 Refs; 3 Annexes.

In the European Union (EU) the risk of plant protection products to aquatic organisms is assessed according to regulation 1107/2009. For this assessment the FOCUS Surface Water Scenarios have been developed. The TOXSWA model is included in the FOCUS Surface Water Software tools to calculate the exposure concentration in the water systems defined in those scenarios. At the national level the TOXSWA model is used to assess the exposure concentration in the water system defined in national scenarios. In this report a description is given of the hydrology in the Dutch and EU water body systems and the fate of pesticides and their metabolites in water and sediment. The pesticide can enter the system by spray drift and/or drainage and run-off. The transport in the water system is described by advection, dispersion and diffusion. The exchange at the water-sediment interface is described based on advection/diffusion. Other processes are sorption, volatilisation at the water - air interface and transformation in both the water layer and the sediment. The formation and transformation of metabolites in both compartments are described. The report presents an outlook on the improvements in the next version as well as on future developments.
\end{abstract}

Keywords: pesticides, modelling, exposure, surface water, aquatic ecosystem, drainage, runoff, spray drift, plant protection product, FOCUS Surface Water

(C) 2016

\title{
Wageningen Environmental Research (Alterra)
}

PO Box 47, 6700 AA Wageningen

Phone: (0317) 4807 00; e-mail:info.alterra@wur.nl

The WOt-technical reports series is published by the Statutory Research Tasks Unit for Nature \& the Environment (WOT Natuur \& Milieu), part of Wageningen University \& Research. This document is available from the secretary's office, and can be downloaded from www.wur.nl/wotnatuurenmilieu

Statutory Research Tasks Unit for Nature \& the Environment, P.O. Box 47, NL-6700 AA Wageningen, The Netherlands. Phone: +31 3174854 71; e-mail: info.wnm@wur.nl; Internet: www.wur.nl/wotnatuurenmilieu

All rights reserved. No part of this publication may be reproduced and/or republished by printing, photocopying, microfilm or any other means without the publisher's prior permission in writing. The publisher accepts no responsibility for any damage ensuing from the use of the results of this study or from the implementation of the recommendations contained in this report. 


\section{Preface}

Since 1999 TOXSWA 1.2 has been applied in the Dutch registration procedure for plant protection products to calculate exposure concentrations for an edge-of-field ditch with constant flow rates. Since 2003 TOXSWA 2.1 and onwards has been applied in the FOCUS_TOXSWA software tools (versions $1.1 .1,2.2 .1$ and 3.3.1) that are used in the EU registration procedure to calculate exposure concentrations in ponds, ditches and streams with transient flow conditions. This document describes the concepts of the TOXSWA kernel 3.3 that is implemented in the FOCUS_TOXSWA v.4.4.3 software tool. We would like to thank Dr. Jos Boesten and Ir. Paulien Adriaanse for the internal review of (parts) this document.

Mechteld ter Horst

Wim Beltman

Erik van den Berg 



\section{Contents}

$\begin{array}{lr}\text { Preface } & 5\end{array}$

$\begin{array}{ll}\text { Contents } & 7\end{array}$

$\begin{array}{lr}\text { Summary } & 9\end{array}$

$\begin{array}{lr}\text { Samenvatting } & 11\end{array}$

$\begin{array}{llr}1 & \text { Introduction } & 13\end{array}$

$2 \quad$ Model for water flow $r$

2.1 Introduction $\quad 15$

2.2 System description - general $\quad 15$

2.2.1 Geometric elements $\quad 15$

$\begin{array}{ll}2.2 .2 \text { Elements of the water balance } & 16\end{array}$

$\begin{array}{ll}2.3 \text { Hydrology of watercourses } & 18\end{array}$

2.3.1 Constant flow 18

2.3.2 Transient flow; constant water depth along length of modelled watercourse $\quad 19$

2.4 Pond systems $\quad 23$

$\begin{array}{ll}2.4 .1 \text { No flow } & 23\end{array}$

$\begin{array}{ll}2.4 .2 \text { Transient flow } & 23\end{array}$

$3 \quad$ Temperature for the modelled system $\quad 25$

$4 \quad$ Pesticide system and conservation equations $\quad 27$

$\begin{array}{lll}4.1 & \text { Water layer } & 27\end{array}$

4.1.1 System description - general $\quad 27$

$\begin{array}{ll}4.1 .2 \text { Conservation equation } & 29\end{array}$

$\begin{array}{lll}4.2 & \text { Sediment } & 29\end{array}$

4.2.1 System description - general $\quad 29$

$\begin{array}{ll}4.2 .2 \text { Conservation equation } & 32\end{array}$

$5 \quad$ Pesticide entry routes $\quad 33$

$\begin{array}{lll}5.1 & \text { Introduction } & 33\end{array}$

$\begin{array}{lll}5.2 & \text { Entry routes at the boundaries } & 33\end{array}$

5.2.1 Entries at the upper boundary

5.2.2 Into sediment via upward seepage $\quad 33$

$\begin{array}{lll}5.3 & \text { Lateral entries in the waterbody - type of inputs } & 33\end{array}$

$\begin{array}{lll}5.4 & \text { Spray drift } & 34\end{array}$

$\begin{array}{lll}5.5 & \text { Drainage, runoff and erosion } & 34\end{array}$

5.5.1 Water layer: drainage and runoff

$\begin{array}{ll}5.5 .2 \text { Sediment: erosion } & 35\end{array}$

$\begin{array}{lll}5.6 & \text { Considerations } & 35\end{array}$

$6 \quad$ Pesticide process of partitioning $\quad 37$

$\begin{array}{lll}6.1 & \text { Water layer } & 37\end{array}$

$\begin{array}{ll}6.2 & \text { Sediment } \\ \end{array}$ 
$\begin{array}{llr}7.1 & \text { Water layer } & 39\end{array}$

7.1.1 Transport by advection and dispersion $\quad 39$

7.1.2 Transport by advection to downstream waterbody $\quad 39$

$\begin{array}{lll}7.2 & \text { Sediment } & 40\end{array}$

7.2.1 Transport by advection, dispersion and diffusion $\quad 40$

$\begin{array}{ll}\text { 7.2.2 Transport by advection to soil } & 42\end{array}$

$\begin{array}{lll}7.3 & \text { Water-sediment interface: advection and diffusion } & 42\end{array}$

$\begin{array}{lll}7.4 & \text { Volatilization from the water layer } & 43\end{array}$

$\begin{array}{lll}7.5 & \text { Effect of temperature } & 44\end{array}$

$\begin{array}{ll}7.5 .1 & \text { Saturated vapour pressure }\end{array}$

$\begin{array}{ll}7.5 .2 \text { Solubility } & 44\end{array}$

$8 \quad$ Pesticide transformation processes $\quad 45$

8.1 Metabolites: reaction scheme and kinetics $\quad 45$

$\begin{array}{lll}8.2 & \text { Water layer } & 46\end{array}$

$\begin{array}{lll}8.3 & \text { Sediment } & 46\end{array}$

$\begin{array}{ll}\text { 8.4 Effect of temperature on transformation rate } & 47\end{array}$

9 General discussion $\quad 49$

9.1 Model sensitivity, verification, use and testing 49

9.1.1 Sensitivity and uncertainty analysis $\quad 49$

$\begin{array}{ll}9.1 .2 \text { Verification } & 49\end{array}$

9.1.3 Model use and testing $\quad 49$

$\begin{array}{lll}9.2 & \text { Ongoing developments } & 49\end{array}$

$\begin{array}{ll}9.2 .1 & \text { Introduction }\end{array}$

$\begin{array}{ll}9.2 .2 \text { Hydrology } & 50\end{array}$

$\begin{array}{ll}\text { 9.2.3 Atmospheric deposition } & 50\end{array}$

$\begin{array}{ll}\text { 9.2.4 Temperature } & 50\end{array}$

$\begin{array}{ll}9.2 .5 \text { Volatilisation } & 50\end{array}$

$\begin{array}{ll}9.2 .6 \text { Bioturbation } & 51\end{array}$

$\begin{array}{ll}\text { 9.2.7 Transformation } & 51\end{array}$

$\begin{array}{lll}9.3 & \text { Landscape scale modelling } & 51\end{array}$

$\begin{array}{lr}\text { References } & 53\end{array}$

$\begin{array}{lr}\text { Justification } & 55\end{array}$

$\begin{array}{llr}\text { Annex } 1 \quad \text { List of symbols and units } & 57\end{array}$

$\begin{array}{lll}\text { Annex } 2 & \text { Lateral entries in the waterbody } & 61\end{array}$

$\begin{array}{lll}\text { A2.1 Introduction } & 61\end{array}$

A2.2 Point-type pulse input $\quad 62$

A2.3 Point-type distributed input $\quad 63$

$\begin{array}{lll}\text { A2.4 Continuous point release } & 64\end{array}$

$\begin{array}{lll}\text { A2.5 Continuous distributed release } & 64\end{array}$

$\begin{array}{lll}\text { Annex } 3 & \text { Iteration solution of the Freundlich sorption equation } & 67\end{array}$ 


\section{Summary}

Pesticides are applied in agricultural fields to control a wide range of pests that would otherwise reduce the quantity and quality of crops. Pesticides may enter surface waters by various routes such as surface runoff, leaching to drains and spray drift deposition. To assess the exposure of aquatic organisms simulation models have been developed to be used in the pesticide regulation at the European level as well as the national level. In the nineties of the last century the TOXSWA model has been developed to assess the behaviour of pesticides in a water-sediment system at the edge-of-field scale. The TOXSWA model has been adopted to be used in the Dutch registration procedure in 1999 (version 1.2) in conjunction with Dutch Surface Water scenarios. For the use of the FOCUS Surface Water Scenarios in the EU authorization procedure TOXSWA versions 2.1 up to 3.3 have been developed and used by the FOCUS-TOXSWA software tools since 2003. The FOCUS-TOXSWA software tools also include ten FOCUS Surface Water scenarios for which the TOXSWA model is run. The latest version of the software tool, i.e. FOCUS-TOXSWA 4.4.3, uses TOXSWA version 3.3. TOXSWA 3.3 includes an option to assess the fate of metabolites formed in either the water layer or the sediment compartment. This report describes the processes for the flow of water in several types of waterbody systems and the processes considered describing the fate of the pesticide in these systems. Descriptions are constrained to those processes used for simulations with the Dutch (excluding the greenhouse scenarios) and FOCUS Surface Water Scenarios.

The hydrology of the waterbody systems depends on their geometry, the elements of the water balance and the procedure to determine the discharge and the water depth. A distinction is made between watercourses and ponds. Two types of water flow regimes are defined for the watercourses: a constant water flow regime and a transient flow. Transient flow means varying discharge and water depth in time and along the length of the waterbody. In TOXSWA the transient flow is modelled for a watercourse of which a stretch has a constant water depth along the length of the waterbody. This watercourse is located adjacent to a treated, agricultural field delivering water originating from drainage or surface runoff to the watercourse. Furthermore, the watercourse is fed by a small catchment. A weir located downstream maintains the water level at a preferred minimum depth. For the ponds the situation of no flow or transient flow can be simulated.

Transient flow in a pond system is simulated by assuming the pond is a reservoir having an incoming and an outgoing water flow. The total incoming flow consists of a constant base flow plus the excess water from the contributing area, delivered into the pond. The contributing area consists of fields located at its banks. The pond outflow occurs across a weir. The incoming excess water from the contributing area originates from e.g. drain pipes or surface runoff and varies in time. For the Dutch Surface Water scenarios a watercourse has been defined with a constant flow system. In this system the flow velocity of water is constant in time and space. For the FOCUS Surface Water scenarios, three types of water bodies have been defined, i.e. ditches, streams and ponds. Hydrology in the FOCUS ditches and streams are simulated according the concept of transient flow with a constant water depth along the length of the modelled water course. The FOCUS pond is simulated using the concept for transient flow in a pond system. The 'no flow' hydrology in a pond system can be used for the simulation of water-sediment systems and microcosms.

For the description of the temperature in the waterbody in the TOXSWA model, a simple approach has been implemented. The temperature in the waterbody system (water layer and sediment) is assumed to remain constant during periods of one month.

The pesticide can enter the waterbody systems in different ways in relation to time and space. The lateral entry can be described by a pulse input or a continuous input (time). For both types the entry can occur at a specific point in the system or it can be distributed over a certain length of the system. Of the in total four types of input, two are actually implemented in TOXSWA (distributed, pulse and distributed, continuous). In addition to the lateral entries, entry routes at the boundaries i.e. upstream 
entries in the waterbody or entries in the sediment via upward seepage can be simulated. In the Dutch scenario only the entry into the water layer by drift (distributed, pulse) is considered. In the FOCUS scenarios, the entry routes for the water layer are the entry from the upstream catchment, the lateral entry (distributed, continuous) due to drainage and runoff and the entry due to spray drift (distributed, pulse). For the sediment compartment the entry types are due to erosion by runoff (distributed, continuous).

In the water layer, sorption of pesticide can be to suspended solids or macrophytes. Sorption of the pesticide to suspended solids is described by a Freundlich sorption equation. The sorption to macrophytes is described using a linear sorption isotherm. The sorption of pesticides to the solid phase of the sediment is described with a Freundlich sorption equation.

The transport of the pesticide in the water layer is described by an equation including advection and dispersion in the horizontal direction. The exchange with the atmosphere is described by diffusion across the water-atmosphere interface. The exchange of pesticide between the water layer and the sediment is described using equations for transport of substance through advection and diffusion across the water-sediment interface. The transport of the pesticide in the sediment is described by an equation including advection, dispersion and diffusion in the vertical direction.

For transformation of the pesticide, the scheme of reactions of the pesticide and its transformation products is translated into a matrix of the molar fractions involved in each of the reactions. Two matrices are defined, one for the water layer and one for the sediment. The rate of transformation of the substances in both compartments is described by first-order kinetics. Pesticide transformation is highly dependent on temperature, which is described by the Arrhenius equation.

The TOXSWA model is an important tool in the evaluation of risks of agricultural pesticide use to the aquatic ecosystem. It can be used for different purposes. TOXSWA calculates exposure concentrations in surface water systems via running scenarios defined in the evaluation tiers of registration procedures at the national and EU levels. TOXSWA can also be applied for specific computations, for example to assess the effect of mitigation measures on exposure concentrations.

Further work on the development of the model has been done in recent years. Currently, the TOXSWA development team is working on the next version: 3.4. One of the improvements that has been implemented in this version of the TOXSWA model is related to the description of the variation in time of the water temperature. As the temperature in small water bodies can vary strongly by changing weather conditions, a 1-D bulk approach has been adopted to describe the terms constituting the energy balance of the waterbody. This new procedure allows taking into account temperature variations at time scales of 1 hour. Furthermore, the team is currently working on implementation of improved concepts for transformation in water. This is done by splitting transformation in water into three separate processes: hydrolysis, photolysis and biotic transformation. Describing these underlying processes enables a better quantification of the overall transformation rate, and thus improves the description of the pesticides' behaviour.

Other improvements are the inclusion of bioturbation as a particle dispersion process and the inclusion of atmospheric deposition as a pesticide entry pathway. Deposition of pesticide on the surface water can occur as a result of volatilisation of pesticide after application to the adjacent field.

At the landscape level, the CASCADE-TOXSWA model has been developed. This model is based on the TOXSWA model, but it only considers the water layer in a system of interconnected water courses. The transport processes considered are advection and dispersion. At present the only entry route considered is deposition due to spray drift. Further improvement of the model would require the inclusion of the sediment compartment. The CASCADE-TOXSWA model could be developed further to assess exposure and the resulting effects of pesticide use at the catchment scale. 


\section{Samenvatting}

Pesticiden worden in de landbouw gebruikt tegen een breed scala aan plagen dat anders zou resulteren in een afname in de gewasopbrengst en de kwaliteit van deze opbrengst. Pesticiden kunnen op verschillende wijzen in het oppervlaktewater terecht komen, bijv. via run-off, uitspoeling naar het oppervlaktewater via drains en depositie van spuitdruppeltjes. Voor de beoordeling van de blootstelling van waterorganismen zijn simulatiemodellen ontwikkeld om te gebruiken in de toelatingsprocedure op zowel nationaal als Europees niveau. In de jaren negentig van de $20^{\mathrm{e}}$ eeuw is het TOXSWA-model ontwikkeld waarmee het gedrag van pesticiden in een water-sediment systeem op veldschaal kan worden beoordeeld. Het TOXSWA-model (versie 1.2) wordt samen met de Nederlandse oppervlaktewaterscenario's sinds 1999 in de Nederlandse toelatingsprocedure gebruikt.

Om de FOCUS oppervlaktewaterscenario's in de EU-toelatingsprocedure toe te passen, zijn TOXSWAmodelversies ontwikkeld, van versie 2.1 tot aan versie 3.3, als onderdeel van de sinds 2003 uitgebrachte FOCUS-TOXSWA-softwarepakketten. De FOCUS-TOXSWA-softwarepakketten bevatten ook de tien FOCUSoppervlaktewaterscenario's waarvoor berekeningen met TOXSWA gedaan kunnen worden. In de recentste versie van dit softwarepakket, FOCUS-TOXSWA 4.4.3, wordt TOXSWA versie 3.3 gebruikt. TOXSWA 3.3 bevat een optie om het gedrag van metabolieten te beoordelen die in de waterlaag dan wel in het sediment gevormd worden. Dit rapport beschrijft de processen voor waterstroming in verschillende oppervlaktewatersystemen en de processen die het gedrag van pesticiden in deze systemen bepalen. De procesbeschrijvingen zijn beperkt tot de processen die relevant zijn in combinatie met de Nederlandse en de FOCUS-oppervlaktewaterscenario's (m.u.v. de NL-glastuinbouwscenario's).

De hydrologie van de watersystemen hangt af van de geometrie van het systeem, de elementen van de waterbalans en de procedure om de waterafvoer en de waterdiepte in het systeem te bepalen. Hierbij wordt een onderscheid gemaakt tussen beken en poelen. Voor beken zijn twee typen waterstromingsregime gedefinieerd: een regime met constante waterstroming en een regime met niet-stationaire waterstroming. Niet-stationaire stroming houdt in dat de afvoer en waterdiepte in de gesimuleerde waterloop veranderen in de tijd en over de lengte van de waterloop. In TOXSWA wordt de niet-stationaire stroming in een waterloop beschreven met een constante diepte over de gehele waterloop. Deze waterloop is gelegen naast een behandeld landbouwkundig perceel, waarvan het drainagewater of de afvoer via run-off in deze waterloop terechtkomt. De waterloop wordt ook gevoed met water uit een bovenstrooms gebied. Aan de benedenstroomse zijde van de waterloop bevindt zich een stuw om een gewenste minimumwaterdiepte in de waterloop te handhaven.

Voor poelen kan TOXSWA een stagnante situatie en niet-stationaire stroming simuleren. Niet-stationaire stroming in een poel wordt gesimuleerd door aan te nemen dat de poel een waterreservoir is met een inkomende en een uitgaande waterstroom. De totale aanvoer van water bestaat uit een basisstroom en het overtollig water van het gebied dat op de poel afwatert. Dit afwaterend gebied wordt gevormd door velden die aan de oever van de poel grenzen. De afvoer van water vanuit de poel gaat via een stuw. Het overtollig water dat vanaf de omringende velden in de poel terechtkomt, bestaat uit afvoer via drainpijpen of oppervlakkige afvoer via run-off en de mate van deze afvoer varieert in de tijd. Voor de Nederlandse oppervlaktewaterscenario's is een waterloop gedefinieerd met een constante waterstroming. In dit systeem is de waterstroming zowel in plaats als in tijd constant.

Voor de FOCUS-oppervlaktewaterscenario's zijn drie watersystemen gedefinieerd, d.w.z. sloten, beken en poelen. De hydrologie in de FOCUS-sloten en -beken wordt beschreven via het concept voor niet-stationaire stroming met een constante waterdiepte over de gehele lengte van de waterloop. De hydrologie in de FOCUSpoel wordt beschreven met het concept voor niet-stationaire stroming in een poelsysteem. De hydrologisch stagnante situatie in een poel kan gebruikt worden voor de simulatie van water-sediment en microkosmossystemen

Om de temperatuur in het watersysteem van het TOXSWA-model te beschrijven, wordt een simpele benadering gebruikt. De temperatuur in het watersysteem (waterlaag en sediment) wordt aangenomen constant te zijn gedurende perioden van één maand. 
Het pesticide kan in het watersysteem terechtkomen op verschillende wijzen in tijd en plaats. De laterale aanvoer kan worden beschreven als een pulsbelasting of als een continue belasting (tijd). Voor beide typen aanvoer kan de belasting plaatsvinden op een specifiek punt in de waterloop of over een deel van de waterloop. Van de vier mogelijke aanvoerroutes zijn er twee geïmplementeerd in TOXSWA, nl. lijn-puls en lijncontinu. Naast de laterale aanvoer zijn er aanvoerroutes aan de grenzen van het watersysteem, nl. door aanvoer van bovenstrooms water en aanvoer via kwel in het sediment-subsysteem. In het Nederlandse scenario wordt alleen de belasting van de waterlaag via drift (lijn, puls) in rekening gebracht. In de FOCUSscenario's zijn de aanvoerroutes voor de waterlaag de aanvoer vanuit het gebied bovenstrooms, laterale aanvoer (lijn, continu) door drainage en run-off en de aanvoer als gevolg van spuitdrift (lijn, puls). Voor het sediment-subsysteem is de aanvoerroute beperkt tot de aanvoer via erosie van bodemdeeltjes (lijn, continu).

In de waterlaag kan de sorptie plaatsvinden aan gesuspendeerde deeltjes en macrofyten. De sorptie aan gesuspendeerde deeltjes wordt beschreven met een sorptievergelijking van Freundlich. De sorptie aan macrofyten wordt beschreven met een lineaire adsorptie-isotherm. De sorptie aan de vaste fase van het sediment-subsysteem wordt beschreven met een sorptievergelijking van Freundlich.

Het transport van het pesticide in de waterlaag wordt beschreven met een vergelijking met termen voor advectie en dispersie in de horizontale richting. De uitwisseling met de atmosfeer wordt beschreven met diffusie over het water-atmosfeer grensvlak. De uitwisseling van pesticide tussen de waterlaag en het sediment wordt beschreven met vergelijkingen voor transport via advectie en diffusie over het grensvlak water-sediment. Het transport van het pesticide in het sediment wordt beschreven met een vergelijking voor advectie, dispersie en diffusie in de verticale richting.

Om het pesticide om te zetten, wordt het reactieschema voor het pesticide en de omzettings-producten vertaald naar een matrix voor de molaire fracties voor elk van de beschouwde reacties. Twee matrices worden gedefinieerd, één voor de waterlaag en één voor het sediment. De snelheid van de omzetting in beide compartimenten wordt beschreven met eerste-orde kinetiek. De omzetting van het pesticide hangt in hoge mate af van de omgevingstemperatuur en dat effect wordt beschreven door de Arrhenius-vergelijking.

Het TOXSWA-model is een belangrijk instrument in de risico-evaluatie van landbouwkundig gebruik van pesticiden voor aquatische systemen. Het model kan gebruikt worden voor verschillende doeleinden. TOXSWA berekent de blootstellingsconcentratie in oppervlaktewatersystemen door gebruik van de scenario's zoals die zijn opgenomen in de beoordelingsniveaus van de toelatingsprocedure op nationaal en EU-niveau. Het TOXSWA-model kan ook worden gebruikt voor specifieke doeleinden, bijvoorbeeld om het effect van emissiereducerende maatregelen op de blootstellingsconcentraties in oppervlaktewater te beoordelen.

Verdere ontwikkeling van het model heeft de laatste jaren plaatsgevonden. Momenteel werkt het TOXSWAontwikkelteam aan de volgende versie, nl. 3.4. Een van de verbeteringen die gerealiseerd is in deze versie van het TOXSWA model betreft de beschrijving van de variatie in de tijd van de watertemperatuur. Aangezien in kleine watersystemen de temperatuur sterk kan variëren onder invloed van de verandering van de weersomstandigheden, is een 1-D bulkbenadering gebruikt om de termen te beschrijven die onderdeel zijn van de energiebalans van het watersysteem. Deze nieuwe benadering maakt het mogelijk om met temperatuurvariaties op een tijdschaal van één uur rekening te houden. Verder werkt het ontwikkelteam momenteel aan de verbetering van de concepten voor de beschrijving van de omzetting in water. Bij de omzetting in water wordt dan rekening gehouden met de bijdragen van afzonderlijke omzettingsmechanismen, hydrolyse, fotolyse en biotische omzetting. Door deze afzonderlijke processen te beschrijven, wordt de totale omzettingssnelheid beter gekwantificeerd en wordt aldus de beschrijving van het gedrag van het pesticide verbeterd.

Andere verbeteringen betreffen de uitbreiding van het model met een beschrijving van bioturbatie als een dispersieproces voor deeltjes en het opnemen van atmosferische depositie als aanvoerroute van het pesticide. Depositie van het pesticide op het oppervlaktewater kan het gevolg zijn van vervluchtiging na toepassing van het middel op het naastgelegen veld.

Op landschapsniveau is het CASCADE-TOXSWA-model ontwikkeld. Dit model is gebaseerd op het TOXSWAmodel, maar het beschrijft alleen het transport van het pesticide in de waterlaag van een stelsel van onderling verbonden waterlopen. Het transport in de waterlaag wordt beschreven door advectie en dispersie. Tot nu toe is de enige aanvoerroute de aanvoer als gevolg van spuitdrift. Verdere ontwikkeling van het model vereist het inbouwen van een sedimentcompartiment. Het CASCADE-TOXSWA-model kan verder ontwikkeld worden om het mogelijk te maken dat de blootstelling en de daardoor veroorzaakte effecten op stroomgebied niveau beoordeeld kan worden. 


\section{Introduction}

World-wide pesticides are applied in agricultural fields to control a wide range of pests that would otherwise reduce the quantity and quality of crops. Pesticides may enter surface water by various routes such as surface runoff, leaching to drains and spray drift deposition. Pesticides may have a negative effect on the aquatic environment (e.g. acute toxicity for aquatic organisms) and may threaten the quality of drinking water abstracted from surface water. Therefore, most countries regulate pesticides via legislation prescribing among others environmental risk assessment procedures for aquatic ecosystems (for instance Regulation (EC) No. 1107/2009 in the EU). An important part of these risk assessment procedures is the calculation of Predicted Environmental Concentrations (PEC) and Time Weighted Average exposure concentrations (TWAs), in both the water layer and the sediment of surface waters using fate models.

In the second half of the nineties, the TOXSWA model, that simulates pesticide behaviour in a watersediment system at the edge-of-field scale, was developed (Adriaanse, 1996). Versions 1.0 and 1.2 simulate constant water depths and discharges and consider only spray drift deposition as entry route of pesticides in the waterbody. From version 2.1 onwards the hydrology has been further developed i.e. simulating a transient flow regime with rapidly varying discharges and water levels in small water courses adjacent to agricultural fields. Furthermore, next to spray drift deposition, pesticide fluxes and water fluxes resulting from drainage and surface runoff (including erosion) can be handled by the model as well (Figure 1). TOXSWA version 3.3 facilitates the formation of metabolites in water and sediment.

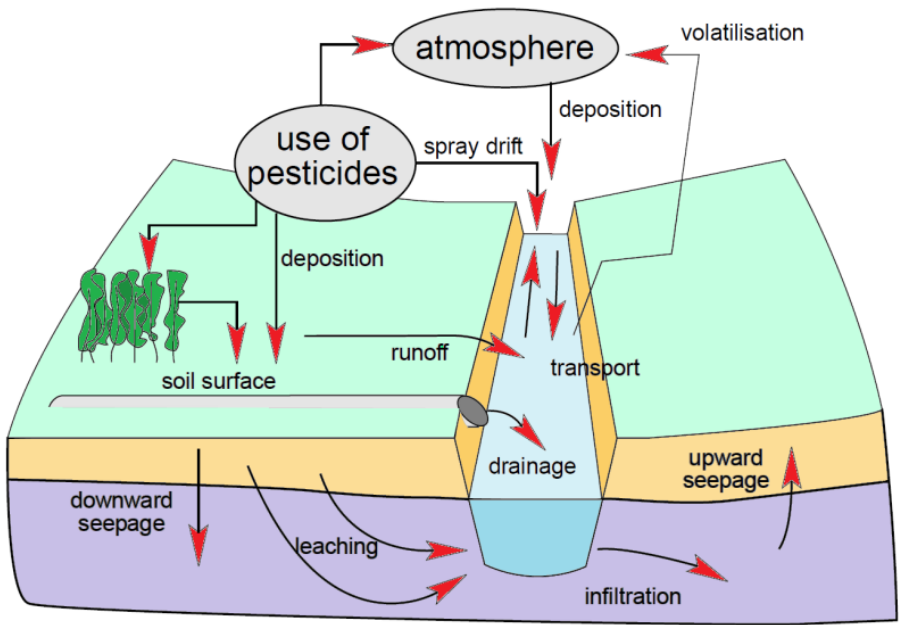

Figure 1 Possible entry routes of pesticides to a waterbody at the edge-of-field scale.

TOXSWA 1.2 has been applied in the Dutch registration procedure for first and higher tier exposure assessments since 1999. Higher tier assessments include the interpretation of field studies for pesticide registration as well as the interpretation of water-sediment studies to determine transformation rates in water and in sediment.

TOXSWA versions 2.1 and onwards are incorporated in the different FOCUS_TOXSWA software tools that have been used in the EU pesticide registration process since 2003. The FOCUS-TOXSWA software tools include ten so-called FOCUS surface water scenarios for which the TOXSWA model is run.

In the FOCUS stream and ditch scenarios, the field-scale system (i.e. waterbody and adjacent field treated with pesticides) is characterized as the downstream part of a catchment. The upstream catchment of the FOCUS stream is partly treated with pesticides; the upstream catchment of the 
FOCUS ditch is not treated. The field-scale system of the FOCUS pond scenario is characterized as a waterbody with an adjacent field that is treated with pesticides. The pond receives a constant inflow of water that is free of pesticides.

This report describes the mathematical concepts of TOXSWA version 3.3 i.e. the TOXSWA kernel that is incorporated in the latest FOCUS_TOXSWA software tool (version 4.4.3; for the manual of this software tool we refer to Beltman et al., 2014). Only those concepts in TOXSWA that are relevant for simulations with the FOCUS surface water scenarios and the Dutch scenarios (TOXSWA 1.2; Beltman and Adriaanse, 1999) are described in Chapter 2-8. Mathematical concepts are described independent of specific scenario properties. Elaboration of the these concepts using the specific parameterizations of the FOCUS Surface Water scenarios can be found in Adriaanse and Beltman (2009) and Adriaanse et al. (in press) considering the hydrology and in Adriaanse et al. (2014) for metabolite formation in the partly treated upstream catchment of the FOCUS stream scenarios.

Furthermore, we limited this report to the description of the processes only i.e. descriptions of the numerical solutions used are not given. Considering the numerical solution used to solve the water conservation equations we refer to Adriaanse and Beltman (2009). Considering the numerical solution used to solve the mass conservation equations for pesticide in water and sediment we refer to Adriaanse (1996).

Chapter 2 of this report describes the different model concepts of TOXSWA used for simulating the hydrology of the waterbody.

Chapter 3 gives the concept for simulating the waterbody temperature.

Chapter 4 is subdivided in a part for the water layer and a part for the sediment. Each part starts with a general description of the processes considered in the specific compartment. This is followed by a section giving the conservation equation, which describes the total mass balance for the pesticide in the compartment considered.

In Chapter 5 pesticide entry routes at the boundaries of the waterbody and entry routes representing lateral entries in the waterbody are described. With respect to the lateral entries, four types of inputs are distinguished. The mathematical elaboration in a general sense is given for each of the four types. However not all four types are implemented in TOXSWA. For those types that are implemented in TOXSWA, the mathematical elaboration of the corresponding specific entry route(s) (e.g. drainage, runoff etc.) is given as well.

Equilibrium partitioning between the solid and the liquid phase is described in Chapter 6 . In the water layer, the solid phase is defined by suspended solids and macrophytes. In the sediment the pore water represents the liquid phase and the sediment particles the solid phase.

Processes considering pesticide transport and emission are described in Chapter 7. First, the transport processes of advection, dispersion, and transport across the downstream end of the water layer are discussed. Next, transport processes in the sediment are discussed (advection, dispersion, diffusion and transport of pesticide across the downward-facing boundary of the sediment). Subsequently, transport processes at the water-sediment interface are specified. Volatilization from the water layer to the atmosphere is included as well in this chapter.

The formation of reaction products in water and sediment and the rates of the transformations are described in Chapter 8.

In Chapter 9 provides information about model sensitivity, verification and use and testing of the TOXSWA model. Furthermore, ongoing model developments are discussed and attention is paid to the role of the TOXSWA model considering assessing pesticide fate in an interconnected system of water courses (landscape modelling) 


\section{Model for water flow}

\subsection{Introduction}

The TOXSWA model calculates pesticide behaviour in waterbodies at the edge-of-field scale, i.e. waterbodies with a maximum length of a few hundred metres adjacent to a single field. The hydrological sub-model of TOXSWA therefore focuses on the same scale, i.e. that of a single edge-offield waterbody. The waterbody setup is used to simulate watercourses and also ponds. Differences between the modelled ponds and water courses basically relate only to the dimensions. Length and width of a pond are in the same order whereas for water courses the length is a factor 10 to 100 larger than the width. This chapter describes how the water flow in the water layer is modelled. The descriptions are based on Adriaanse et al. (2017), Adriaanse (1996) and Adriaanse and Beltman (2009).

In Section 2.2 a general description of the waterbodies and their hydrology simulated by TOXSWA is given. The different options for simulation of water flow of watercourses are described in Section 2.3, and the different options for the simulation of water flow of ponds in Section 2.4. For each of the options first the position of the modelled system in the landscape is described, secondly the elements of the water balance that are considered in the system, and finally how discharge and water depth in the waterbody are determined.

\subsection{System description - general}

\subsubsection{Geometric elements}

The waterbody system is characterized as follows (see Figure 2):

- the cross section of the waterbody is shaped as an isosceles trapezium ${ }^{1}$ and the wetted perimeter separates the water layer from the neighbouring soil,

- discharge and water level in the waterbody varies in time and along its length,

- upward, downward and lateral flow occur through the bottom and walls of the waterbody.

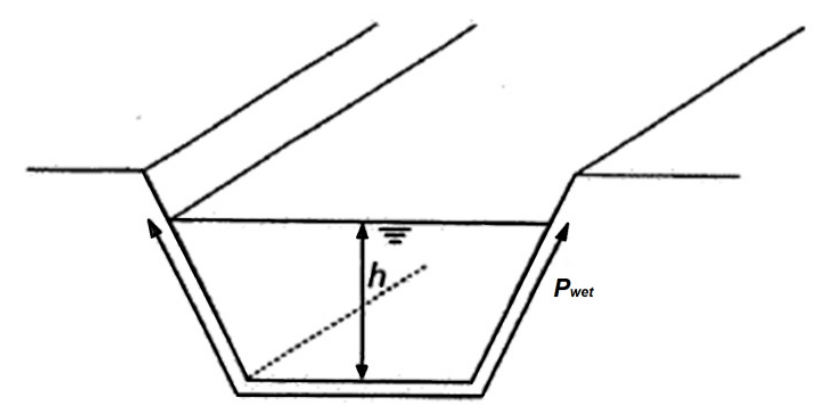

Figure 2 Outline of model system.

with

$h \quad=$ water depth of the waterbody $(\mathrm{m})$

$P_{\text {wet }} \quad=$ length of wetted perimeter of a waterbody $(\mathrm{m})$

\footnotetext{
${ }^{1}$ Note that a rectangle is a special form of a trapezium-shape. For the FOCUS waterbodies this rectangular shape was used. For ponds it is common to use the rectangular shape.
} 
The coordinate system is defined as follows (Figure 3):

$x$-axis: positive in the most frequent direction of flow in the waterbody;

$z$-axis: positive with depth, zero at the sediment surface;

$y$-axis: perpendicular to the $x$-axis and the $z$-axis.

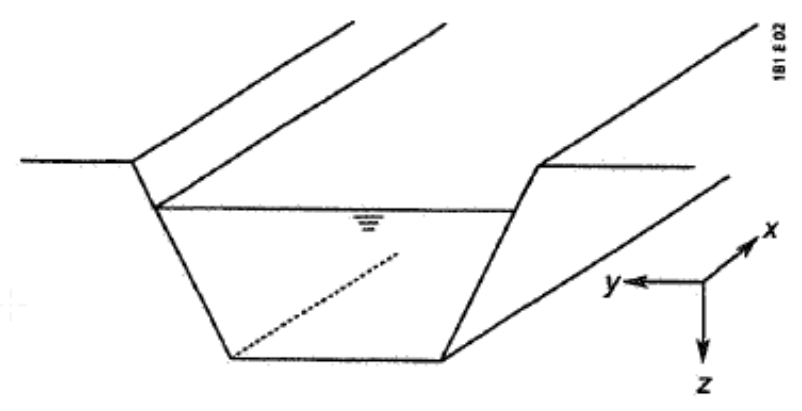

Figure 3 Definition of the coordinate system.

The shape of the wetted cross-section of the waterbody is shown in Figure 4.

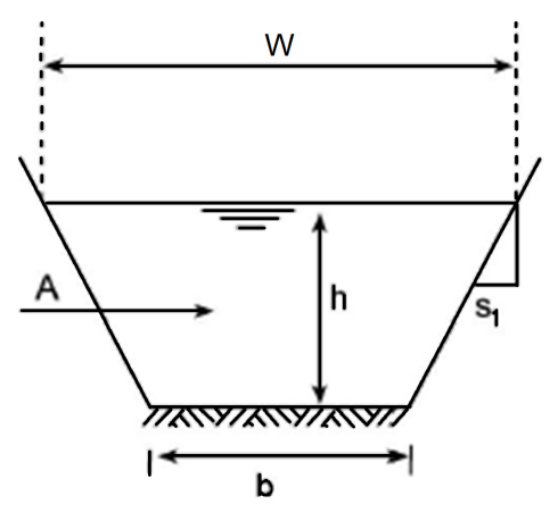

Figure 4 Cross-section of the waterbody.

with

A = wetted cross sectional area for water flow $\left(\mathrm{m}^{2}\right)$

$b=$ bottom width of the waterbody $(\mathrm{m})$

$s_{1} \quad=$ side slope (horizontal/vertical) $(-)$

W $\quad=$ width of water surface $(\mathrm{m})$

The cross-sectional area $A$ of water flow is given by:

$A=b h+s_{1} h^{2}$

The width of the water surface $W$ equals (Figure 4 ):

$W=b+2 s_{1} h$

\subsubsection{Elements of the water balance}

The inflow across the upper boundary can vary in time and consists of two components: (i) a base flow, which may be constant and (ii) a variable excess water flow from the catchment.

In addition to the inflow of water across the upper boundary, there is a lateral inflow, consisting of the excess water from the adjacent field. The excess water originates from e.g. drain pipes or surface runoff from the adjacent field. It is a function of precipitation, soil type, land use etc. 
Because excess water from the adjacent field enters the watercourse, the flux of water is a function of the distance in the direction of flow. A one-dimensional water conservation equation can be developed for the elemental volume $A \Delta x$, in which $A$ represents the cross-sectional surface area perpendicular to the direction of flow (Figure 5).

The water conservation equation for the water layer in the edge-of-field waterbody is:

$\frac{\partial A}{\partial t}=-\frac{\partial Q}{\partial x}+\Phi+P_{r} \cdot W+E \cdot W-S \cdot P_{w e t}$

with:

$t \quad=$ time $(\mathrm{d})$

$Q \quad=$ discharge, i.e. volume flux of water passing through a vertical cross-section of the waterbody $\left(\mathrm{m}^{3} \mathrm{~d}^{-1}\right)$

$x \quad=$ distance in the direction of flow $(\mathrm{m})$

$\Phi \quad$ = lineic volume flux of water, that is lateral inflow originating from drainage or runoff and drainage subsurface flow from the adjacent field $\left(\mathrm{m}^{3} \mathrm{~m}^{-1} \mathrm{~d}^{-1}\right)$

$P_{r} \quad=$ areic volume flux from precipitation, i.e. volume of precipitation divided by an appropriate waterbody surface area and by time; the flux is positive in a downward direction $\left(\mathrm{m}^{3} \mathrm{~m}^{-2} \mathrm{~d}^{-1}\right)$

$E \quad=$ areic volume flux from evaporation; the flux is negative in an upward direction $\left(\mathrm{m}^{3} \mathrm{~m}^{-2} \mathrm{~d}^{-1}\right)$

$S \quad=$ areic volume flux from seepage expressed per appropriate sediment surface area, i.e. volume of water seeping upward or downward; the flux is positive in a downward direction $\left(\mathrm{m}^{3} \mathrm{~m}^{-2} \mathrm{~d}^{-1}\right)$

The lineic volume flux from the adjacent field equals:

$\Phi=w_{F} \cdot q_{F}$

with:

$W_{\mathrm{F}} \quad=$ width of the adjacent field (perpendicular to the waterbody) discharging drainage or runoff water into the waterbody $(\mathrm{m})$

$q_{\mathrm{F}} \quad=$ areic volume flux of excess water from the adjacent field $\left(\mathrm{m}^{3} \mathrm{~m}^{-2} \mathrm{~d}^{-1}\right)$

The (upward or downward) seepage in the sediment equals:

$S=\frac{w_{F}}{P_{w e t}} q_{F, S}$

with

$q_{\mathrm{F}, \mathrm{S}} \quad=$ areic volume flux from seepage flow ${ }^{2}$ from the adjacent field, expressed per surface area adjacent field $\left(\mathrm{m}^{3} \mathrm{~m}^{-2} \mathrm{~d}^{-1}\right)$

\footnotetext{
${ }^{2}$ The seepage flux $q_{\mathrm{F}, \mathrm{S}}$ is a flux of the adjacent field that results in a flux through the water-sediment interface. Upwards seepage results in a negative $q_{F, s}$.
} 


\section{At time $t$.}

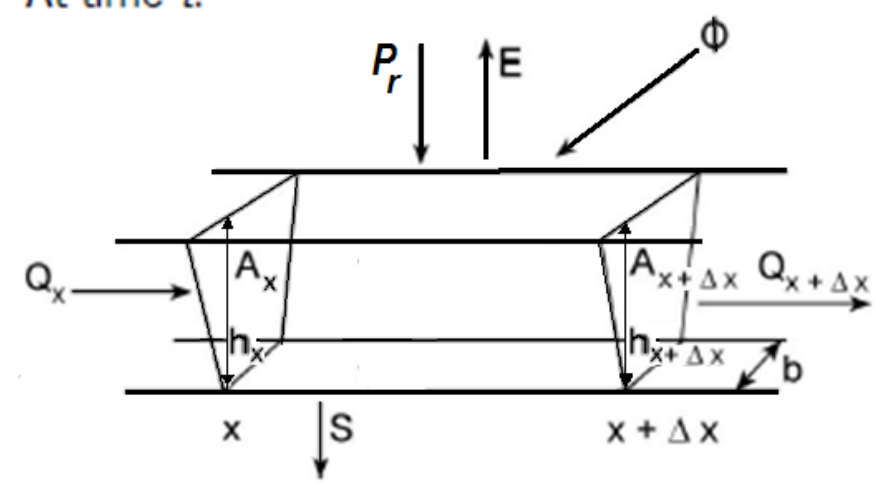

At time $t+\Delta t$.

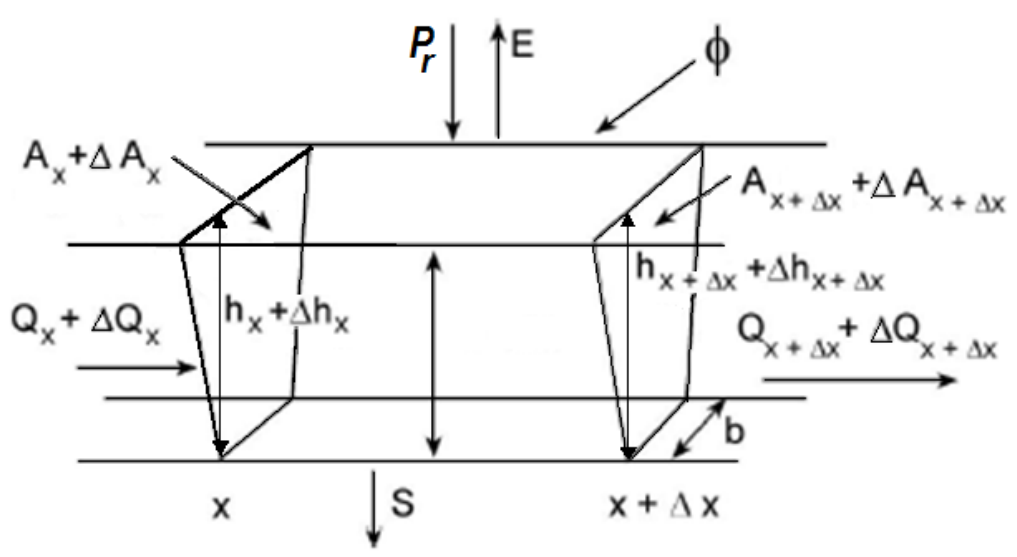

Figure 5 Elemental volume in the edge-of-field waterbody at times $t$ and $t+\Delta t$, with its main water balance components.

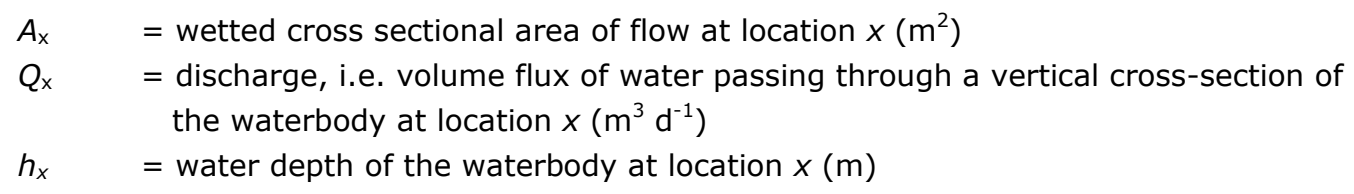

\subsection{Hydrology of watercourses}

\subsubsection{Constant flow}

This type of hydrology has been used for the Dutch scenario with spray drift entries only (Beltman \& Adriaanse, 1999).

The system is a watercourse in which the discharge and the water depth are constant over the whole length of the waterbody and also constant in time. Hence also the flow velocity of water is constant over the full length of the watercourse, and in time.

For this system all terms in the water conservation equation are zero, except the inflow and outflow of water which are equal. 


\subsubsection{Transient flow; constant water depth along length of modelled watercourse}

\section{Introduction}

This type of hydrology has been used for the FOCUS ditch and the FOCUS stream scenarios (FOCUS, 2001). The two FOCUS watercourses are $100 \mathrm{~m}$ long and have a rectangular cross-section, so $s_{1}=0$.

Transient flow means varying discharge and water depth in time and along the length of the waterbody. In TOXSWA 3.3 the transient flow is modelled with a constant water depth along the length of the waterbody. However, a concept for gradual, varied flow (discharge and water depth vary in time and along the length of the waterbody) is available (Opheusden et al., 2011), but not yet implemented.

In the next section it is explained how the discharge and the water depth in the modelled watercourse are calculated for the type of hydrology defined here as "transient flow; constant water depth along the length of the modelled water course". With "modelled watercourse" we refer to that part of the watercourse that is situated along an agricultural field and of which simulated concentrations are used in exposure assessment of pesticide registration procedures. The text of the next sections is based upon Adriaanse et al. (2017).

\section{Position of the watercourse in the landscape}

The modelled watercourse is located at the downstream end of a small catchment, enabling simulation of a realistic transient flow regime. The size of the catchment may vary from a few to a few hundred hectares. A small weir located downstream in the watercourse maintains the water level next to the adjacent field at a specified minimum depth (Figure 6). It is assumed that excess water fluxes (e.g. drainage, surface runoff) of the agricultural fields in the upstream catchment equal the excess water fluxes from the adjacent field.

The water flow in the modelled watercourse is described by assuming the water depth to be constant over the length of this watercourse, so the water depth only varies in time.

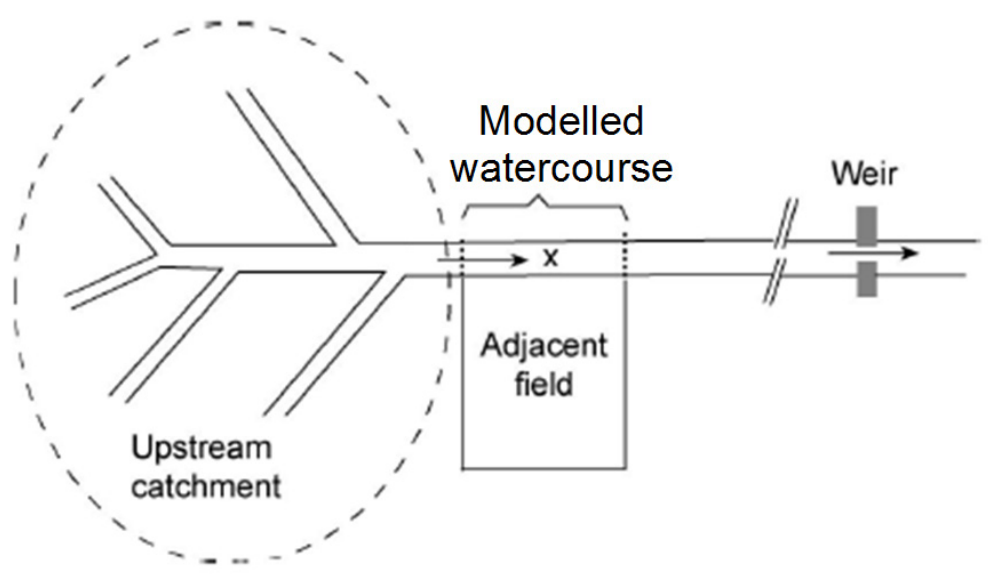

Figure 6 Schematic layout of the modelled watercourse along the adjacent field, including upstream catchment and weir.

\section{Elements of water balance}

The water balance is set up for the modelled watercourse along the total length of the adjacent agricultural field where $x$ ranges from 0 to the total length of the adjacent agricultural field. The water conservation equation of Eq. (3) is simplified to ${ }^{3}$ :

$$
\frac{\partial Q}{\partial x}=-\frac{\partial A}{\partial t}+\Phi+S P_{w e t}
$$

\footnotetext{
${ }^{3}$ The precipitation and evaporation terms of the general water balance (see section 2.2.2) were not implemented for the modelled watercourse. The seepage term is implemented in TOXSWA. However, in the parameterization of the FOCUS Surface Water scenarios the seepage flux, $q_{F, s}$ is set to zero.
} 
The upstream boundary condition of Eq. (6) is the water flow rate coming out of the upstream catchment. This consists of (i) a small constant base flow from the upstream catchment, and (ii) either variable drainage water fluxes from the agricultural fields of the upstream catchment or highly variable runoff water fluxes and (iii) subsurface drainage water fluxes, both from the agricultural fields of the upstream catchment. Hence:

$Q_{u}=Q_{\text {base }}+10^{4} q_{F} A_{u p}$

with

$Q_{\mathrm{u}} \quad=$ total discharge or volume flux of water entering the waterbody at the upstream boundary $\left(\mathrm{m}^{3} \mathrm{~d}^{-1}\right)$

$Q_{\text {base }}=$ discharge or volume flux of the base flow delivered by the upstream catchment $\left(\mathrm{m}^{3} \mathrm{~d}^{-1}\right)$

$A_{\text {up }} \quad=$ size of the upstream catchment area (ha)

$10^{4}=$ factor to convert $\mathrm{m} \cdot$ ha into $\mathrm{m}^{3}\left(\mathrm{~m}^{3}(\mathrm{~m} \mathrm{ha})^{-1}\right)$

In case runoff fluxes are supplemented with subsurface drainage water fluxes, the flux of excess water from the adjacent field, $q_{\mathrm{F}}$ is calculated with:

$q_{F}=q_{F, r}+f_{d} \cdot q_{F, \text { down }}$

with

$q_{\mathrm{F}, \mathrm{r}} \quad=$ areic volume flux of surface runoff excess water from the adjacent field, $\left(\mathrm{m}^{3} \mathrm{~m}^{-2} \mathrm{~d}^{-1}\right)$

$f_{\mathrm{d}} \quad=$ fraction of downward aeric volume flux of water at $1 \mathrm{~m}$ soil depth that is drained into the modelled water course (-)

$q_{\mathrm{F} \text {,down }}=$ areic volume flux of excess water at $1 \mathrm{~m}$ soil depth originating from the adjacent field, $\left(\mathrm{m}^{3} \mathrm{~m}^{-2} \mathrm{~d}^{-1}\right)$

Note that the flux of excess water from the adjacent field, $q_{\mathrm{F}}$ is to calculate $\Phi$ in Eq. (4).

\section{Discharge and water depth}

To be able to solve the water balance (Eq. (6)) in the modelled watercourse we need to determine one of the two unknown variables of this equation, $A$ or $Q$. We opted for $A$, i.e. the water depth $h$ in the watercourse (see Figure 5). Thus, by imposing a water depth $h$ as a function of time it is theoretically possible to calculate the discharge $Q$ as a function of distance in the modelled watercourse.

To do so, we calculated the water depth $h$ for the entire watercourse, i.e. from the weir up to the upper boundary of the entire watercourse. The modelled water course is found somewhere between the weir and the upper boundary of the entire watercourse. Uniform flow conditions prevail at the upper boundary of the entire watercourse (Figure 7).

We first simplified the stream flow into a flow with a constant discharge along the total length of the entire watercourse by excluding the lateral water inflow from the adjacent field. Only the water flow delivered by the upstream catchment $\left(Q_{u}\right)$ is considered. The simplification is adequate when the lateral inflow is small compared to the water flow delivered by the upstream catchment $Q_{u}$ (e.g. for FOCUS stream scenarios with its 100 ha size upstream catchment and 1 ha agricultural field adjacent the $100 \mathrm{~m}$ FOCUS stream the lateral inflow adds only $1 \%$ to the main stream flow). In case the lateral inflow is in the same order of magnitude as the water flow delivered by the upstream catchment $Q_{u}$ (e.g. for FOCUS ditch scenarios with its 2 ha size upstream catchment and 1 ha agricultural field adjacent to the $100 \mathrm{~m}$ FOCUS ditch), the simplification into a constant discharge may impact the calculated water depth in the watercourse. As the numerical solution of the pesticide mass conservation equation for the water layer does take lateral water inflow into account, the impact on calculated pesticide concentrations is expected to be minor (especially for FOCUS ditch scenarios with its water depth varying between approximately 0.3 and $0.36 \mathrm{~m}$ ). 


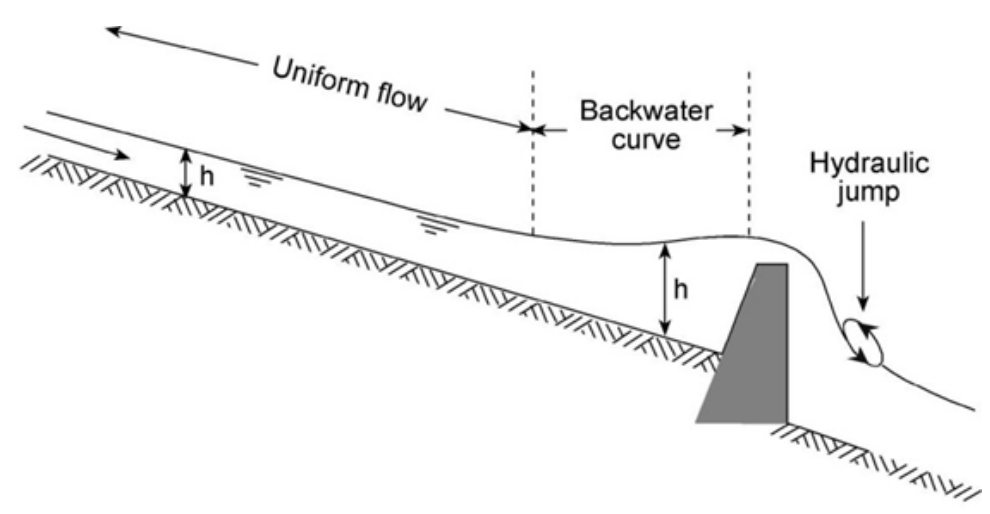

Figure 7 Schematic representation of the water level in the watercourse. At some distance upstream of the weir, the backwater curve has reached the uniform flow depth. The water depth increases travelling in a downstream direction towards the weir. Note that the vertical scale is exaggerated compared to the horizontal scale.

The water depth $h$ as a function of $Q_{u}$ is calculated in four steps:

(1) calculation of the uniform flow depth at the upper boundary of the entire watercourse, $h_{\text {uni }}$;

(2) calculation of the water depth in front of the weir at the downstream end of the watercourse, $h_{\text {weir }}$;

(3) interpolation of the water depth as function of distance between $h_{\text {uni }}$ and $h_{\text {weir }}$ and

(4) selection of the water depth at the entrance of the modelled watercourse, i.e. at $x=0 \mathrm{~m}$.

The value of the water depth at the entrance of the modelled watercourse calculated in step 4 is taken to be the water depth for the full length of the modelled watercourse.

Calculation of uniform flow depth

At some distance upstream in the watercourse the water flow is not influenced anymore by the weir (Figure 7), and there is equilibrium between the friction forces and the gravitation forces on the waterbody; assuming constant watercourse properties, such as width, bottom slope and bottom roughness this so-called uniform flow is characterized by a water depth and discharge that are constant along the watercourse length. Because the discharge equals the known $Q_{u}$ the constant uniform flow depth can be calculated by the widely used Chézy-Manning formula (e.g. Vennard and Street, 1976):

$Q_{u}=A R_{w e t^{2 / 3}} \kappa_{M} G^{1 / 2}$

with

$R_{\text {wet }}=$ hydraulic radius of the wetted cross-section $(\mathrm{m})$

$\kappa_{\mathrm{M}} \quad=$ Manning's coefficient of channel roughness $\left(\mathrm{m}^{1 / 3} \mathrm{~d}^{-1}\right)$

$G \quad=$ slope of the energy line, for uniform flow equal to the hydraulic gradient (difference in water surface level at two locations divided by their distance), which is for uniform flow also equal to the bottom slope $(-)$.

The hydraulic radius $R_{\text {wet }}$ equals:

$R_{w e t}=\frac{A}{P_{w e t}}$

The wetted perimeter of the waterbody $P_{\text {wet }}$ equals:

$P_{w e t}=b+2 h \sqrt{s_{1}^{2}+1}$

For small watercourses Manning's coefficient for channel roughness is a function of water depth according to the empirical relationship: 
$\kappa_{M}=\kappa_{M, 1 m} h_{u n i}^{1 / 3}$

with

$\kappa_{\mathrm{M}, 1 \mathrm{~m}}=$ coefficient defining Manning's coefficient for channel roughness in a channel with a $1 \mathrm{~m}$ water depth $\left(\mathrm{d}^{-1}\right)$ (Querner, 1993)

$h_{\text {uni }}=$ uniform flow depth, i.e. water depth at uniform flow (m)

Eq. (9) needs to be solved in combination with Eq. (1), (10), (11) and (12) to find the uniform flow depth $h_{\text {uni }}$. Using this set of equations $h$ must be replaced by $h_{\text {uni }}$.

Calculation of the water depth in front of the weir

At the downstream end of the watercourse a freely-outflowing weir is located, raising or lowering the uniform flow depth immediately in front of the weir. As the weir has a free outflow its downstream water level does not influence its upstream water level and therefore the water level over the weir crest can be calculated by the so-called head-discharge relation ${ }^{4}$, relating the upstream water level over the crest to the discharge over the weir (Bos, 1976). Hence:

$Q_{\text {weir }}=C_{\text {weir }} b_{\text {crest }} h_{\text {crest }}^{3 / 2}$

with

$Q_{\text {weir }}=$ discharge at the location of the weir $\left(\mathrm{m}^{3} \mathrm{~d}^{-1}\right)$

$C_{\text {weir }}=$ discharge coefficient, depending on weir characteristics $\left(\mathrm{m}^{1 / 2} \mathrm{~d}^{-1}\right)$

$b_{\text {crest }} \quad=$ width of weir crest $(\mathrm{m})$

$h_{\text {crest }} \quad=$ upstream water level over the weir crest, also called head (m)

As we simplified the watercourse flow into a flow constant over the entire watercourse, the upstream water level over the weir crest $h_{\text {crest }}$ can be calculated by using $Q_{u}$ in the head-discharge relation, so by substituting $Q_{u}$ for $Q_{\text {weir }}$ in Eq. (13).

The water depth $h_{\text {weir }}$ immediately in front of the weir equals:

$h_{\text {weir }}=p_{\text {weir }}+h_{\text {crest }}$

with

$h_{\text {weir }} \quad=$ water depth immediately in front of weir $(\mathrm{m})$

$p_{\text {weir }} \quad=$ height of weir crest above waterbody bottom $(\mathrm{m})$

Interpolation of the water depth as function of distance

The water depth as a function of distance for the entire watercourse is obtained by interpolation between $h_{\text {uni }}$ and $h_{\text {weir. }}$. At the upper end uniform flow prevails and thus, the water depth equals the constant uniform flow depth, $h_{\text {uni }}$. Going downstream the uniform flow regime is disturbed by the weir. For small discharges the weir may dam up, i.e. raise the water level, while for large flows the weir may draw down, i.e. lower the water level in front of the weir. The disturbed water level profile, a socalled backwater curve, is obtained by interpolation using the Direct Step method (e.g. Chow, 1959; Akan, 2006). The Direct Step method starts with $h_{\text {weir }}$ at the weir and moves in upstream direction until $h_{\text {uni }}$ is reached. It is characterized by dividing the total water depth change into small steps, corresponding to short watercourse sections and is based upon the assumption that within the short sections energy is lost by friction only (so not by e.g. turbulences). For a given watercourse, the length of the backwater curve is a function of discharge as well as the difference between $h_{\text {uni }}$ and $h_{\text {weir. }}$. The length of the backwater curve varies in time and generally equals a few tens to hundreds of meters.

\footnotetext{
${ }^{4}$ The relation is valid for a weir with a rectangular shaped opening
} 
Selection of the water depth at the entrance of the watercourse

Out of the obtained water level profile we finally select the water depth $h$ at a distance $L_{d-w}$ (scenario dependent) upstream of the weir, corresponding to the entrance of the modelled watercourse, i.e. at $x$ $=0 \mathrm{~m}$. We thus obtain a constant water depth $(h$ at $\mathrm{x}=0 \mathrm{~m})$ for the modelled watercourse as a function of time. This value of $h$ is used to solve the water conservation equation, Eq. (6) ${ }^{5}$ which results in $Q_{u}$ as a function of $x$.

Note that the distance $L_{d-w}$ is a scenario property with a fixed value for the entire simulation period. The distance between $h_{\text {uni }}$ and $h_{\text {weir }}$ is variable in time. Consequently, it may happen that for a certain time $h$ at a distance $L_{\text {d-w }}$ equals $h_{\text {uni. }}$. However, $h$ at a distance $L_{\text {d-w }}$ can also equal a water depth somewhere between $h_{\text {uni }}$ and $h_{\text {weir }}$ i.e. a water depth found somewhere in the backwater curve.

\section{$2.4 \quad$ Pond systems}

\subsubsection{No flow}

This type of hydrology is used for simulation of water-sediment systems (Ter Horst and Koelmans, 2016; Beltman et al., 2015) and microcosms (Deneer et al., 2016). These water-sediment systems have a rectangular cross-section, i.e. $\mathrm{s}_{1}=0$.

The system is a pond in which the water depth has a fixed value and there is no flow, hence $A=$ constant and $Q=0$ in Figure 5 .

In the water conservation for this system all terms are zero. Because the discharge is zero, also the flow velocity is zero.

\subsubsection{Transient flow}

\section{Introduction}

This type of hydrology has been used for the FOCUS pond scenarios (FOCUS, 2001). These ponds have a rectangular cross-section, i.e. the side slope; horizontal/vertical is zero. The concept for transient flow in ponds presented here is only valid in case incoming base flows and excess water fluxes from the contributing areas are small compared to the pond volume and consequently a head over the weir crest that is in the order of a few centimetres.

\section{Position of the pond in the landscape}

A pond is a reservoir having an incoming and an outgoing water flow. Fields that may be located at its bank deliver their excess water into the pond; these fields are called the contributing area (Figure 8). The total incoming flow consists of a constant base flow plus the excess water from the contributing area, delivered into the pond. The pond outflow occurs across a weir. The incoming excess water from the contributing area originates from e.g. drain pipes or surface runoff. Since it is a function of precipitation, soil type, land use etc., the excess water fluxes vary in time. The water depth in the pond only varies in time.

\footnotetext{
${ }^{5}$ Next to the hourly $h$ valuesTOXSWA calculates values of $h$ at time step divisions of the hour for linearly interpolated values of the hour values of $Q_{u}$. The water balance equation is numerically solved with the aid of an explicit finite-difference solution scheme. The hourly input values of drainage/runoff are interpolated with time steps divisions of the hour to transform the sudden large, discontinuous increases in inflow $Q_{u}$ into more realistic smooth increases in $Q_{u}$ : for instance an increase of the base flow of around $10-20 \mathrm{~m}^{3} / \mathrm{h}$ up to a $Q_{u}$ of $2000 \mathrm{~m}^{3} / \mathrm{h}$, i.e. $2 \mathrm{~mm} / \mathrm{h}$ from 100 ha, is subdivided into e.g. six steps with $2000 \mathrm{~m}^{3} / \mathrm{h}$ being the highest value. Because the inflow $Q_{u}$ is not linearly related to $h$ (Eq. 9-11), the water depth $h$ is not linearly interpolated within each hour. Instead it is e.g. six times within the hour calculated with the aid of the interpolated $Q_{u}$ and the backwater curve in front of the weir and thus, within each hour six times the $Q$ profile (Eq. 7) is obtained. In this way the highly dynamic flow is represented more realistically. Finally, hourly values of $Q$ and $h$ are transferred to the numerical solutions of the mass balances (Adriaanse and Beltman, 2009).
} 


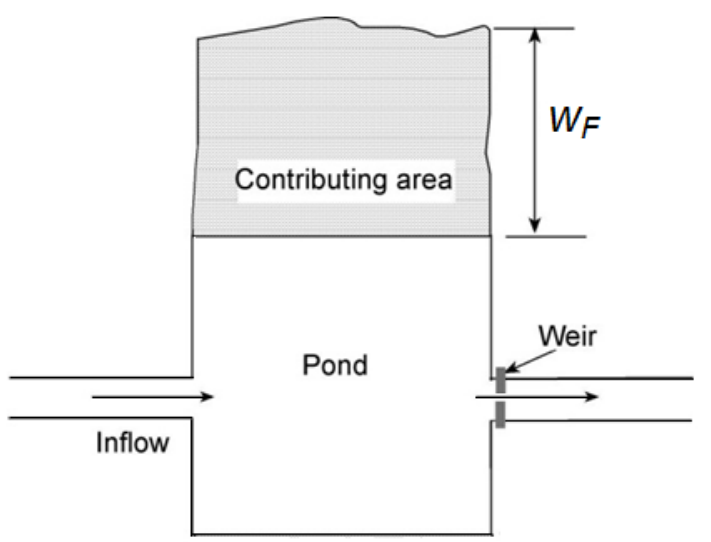

Figure 8 Schematic layout of the pond with inflow, contributing area with total width $w_{F}$ and weir.

When the area of the contributing area to the pond is given, the width of the adjacent field, $\mathrm{w}_{\mathrm{F}}$, is calculated with:

$w_{F}=\frac{A_{\text {contr }, \text { pond }}}{L}$

with:

$A_{\text {contr,pond }}=$ area next to the pond contributing water to the pond $\left(\mathrm{m}^{2}\right)$

$L \quad=$ length of the pond $(\mathrm{m})$

\section{Elements of water balance}

The water balance is set up for the pond. The water conservation equation of Eq. (3) is simplified to ${ }^{6}$ :

$\frac{\partial Q}{\partial x}=-\frac{\partial A}{\partial t}+\Phi+S P_{w e t}$

The upstream boundary condition of Eq. (6) corresponds to the incoming water flow:

$Q_{u}=Q_{\text {base }}$

\section{Discharge and water depth}

A weir, located at the outlet of the pond, governs the pond's discharge (see Figure 9). The discharge of the pond at the location of the weir $Q_{\text {out }}$ is calculated with:

$Q_{\text {out }}=Q_{u}+L \cdot \Phi$

We use $Q_{\text {out }}$ in the head-discharge relation of Eq. 13 . Hence by filling in $Q_{\text {out }}$ for $Q_{\text {weir }}$ in Eq. (13), then combined with Eq. (14) $h_{\text {weir }}$ is calculated. This value of $h_{\text {weir }}$ is used for the water depth in the pond, $h$. This $h$ is used to solve the water conservation equation, Eq. (16) which results in $Q_{u}$ as a function of $x$.

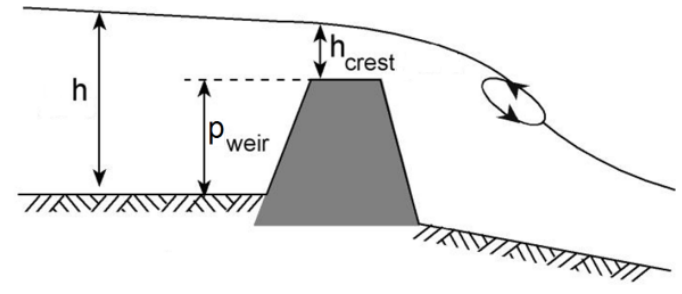

Figure 9 Schematic representation of the water depth in the pond.

\footnotetext{
${ }^{6}$ The precipitation and evaporation terms of the general water balance (see section 2.2.2) were not implemented for the modelled watercourse. The seepage term is implemented in TOXSWA. However, in the parameterization of the FOCUS Surface Water scenarios the seepage flux, $q_{F, s}$ is set to zero.
} 


\section{Temperature for the modelled system}

The temperature in the water layer and in the underlying sediment system depends on the meteorological conditions. This temperature can be expected to vary with the depth in the water layer and the depth in the sediment layer, but also with the horizontal position in the water layer. To include the effect of weather conditions on the course of the temperature with time, depth and distance would require descriptions of the terms and fluxes that contribute to the energy balance of the system. In TOXSWA version 3.3, a simple approach has been implemented. Using this approach, the temperature in the waterbody system (water layer and sediment) is assumed to remain constant during periods of one month. Monthly average water temperatures can be calculated from daily measurements of water temperature. However, if measurements are not available, the monthly temperature can be obtained from daily averages of the air temperature:

$T_{w b}=T_{a, m}$

with

$T_{w b} \quad=$ temperature of the waterbody $(\mathrm{K})$

$T_{a, \mathrm{~m}} \quad=$ monthly average of the air temperature at $2 \mathrm{~m}$ above the ground $(\mathrm{K})$

When the calculated monthly temperature is below $277.15 \mathrm{~K}\left(4^{\circ} \mathrm{C}\right)$, the temperature in the TOXSWA simulation remains at $277.15 \mathrm{~K}$. Reasoning for this minimum temperature of $277.15 \mathrm{~K}\left(4^{\circ} \mathrm{C}\right)$ is as follows. When freezing conditions occur and sustain, ice is formed at the top and grows downwards. During this freezing process, the temperature of the water at the bottom of the waterbody remains around 277.15 K (De Bruin and Wessels, 1988). 



\section{$4 \quad$ Pesticide system and conservation equations}

\subsection{Water layer}

\subsubsection{System description - general}

In the water layer, the substance is subject to the following processes (see Figure 10).

- Advection and dispersion in $x$-direction.

- Exchange with the atmosphere, through a diffusive flux across the water-atmosphere interface.

- Exchange with the sediment, through advection, dispersion and diffusion across the wetted perimeter.

- Sorption to suspended solids and to macrophytes.

- Transformation, described as overall transformation of substance dissolved, sorbed to suspended solids and sorbed to macrophytes.

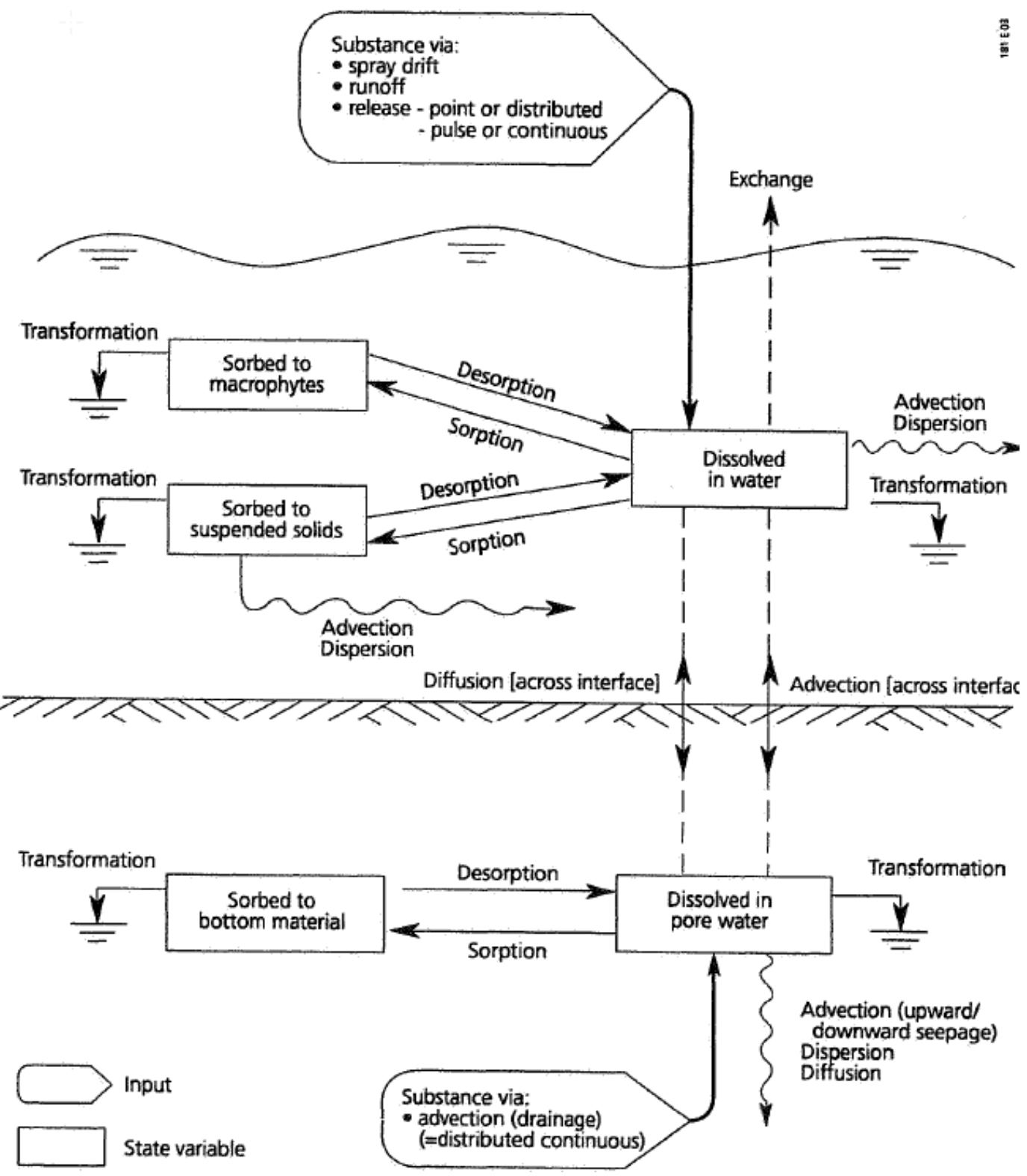

Figure 10 Diagram of modelled processes. 
Diffusion in the $x$-direction has not been included, as dispersion prevails; the dispersion process exists even in stagnant waters, due to e.g. wind effects and inversion of the water layer caused by temperature changes between day and night.

The suspended solids concentration is assumed to be constant. The suspended solids flow along with water. Assuming a constant suspended solids concentration implies that when water is entering the waterbody (from upstream, from drains, by precipitation etc.) suspended solids will enter as well. These incoming suspended solids do not contain pesticides upon entering the waterbody. However, immediately the total mass of pesticide present in the water layer is redistributed in the model and the pesticides sorb to the incoming suspended solids. Consequently the concentration of pesticides dissolved in the water phase will decrease (that is, not only by dilution, but also by sorption to the incoming suspended solids). Pesticides sorbed to suspended solids are subject to the same advection and dispersion as pesticides dissolved in the water phase.

The sedimentation or resuspension of suspended solids is not taken into account. This describes well the following two cases: (i) weakly to moderate pesticide sorption and/or small mass of suspended solids and (ii) relatively short periods, or over somewhat longer periods in clear, moderately eutrophic waterbodies. For these cases pesticide remain mainly in the dissolved phase and the mass on the suspended solids is negligibly small. However, for strongly sorbing pesticides and or simulation of turbid hypertrophic waterbodies for longer periods sedimentation and resuspension cannot be disregarded.

The water layer is assumed to be ideally mixed horizontally and vertically ( $y$ - and z-directions; Figure 3 ) and the substance shows a concentration gradient only in the direction of flow (hence, only $x$ direction and not in $y$ - and $z$-direction). This means that a one-dimensional mass balance can be drawn up for the elemental volume $A \Delta x$, in which $A$ represents the wetted surface perpendicular to the direction of flow.

The mass balance for the substance in the water layer is depicted Figure 11, with

$c_{w}{ }^{*} \quad=$ mass concentration of substance in water layer, including substance sorbed to suspended solids and to macrophytes $\left(\mathrm{kg} \mathrm{m}^{-3}\right)$

$J_{w} \quad=$ areic mass flux of substance in water layer by advection and dispersion $\left(\mathrm{kg} \mathrm{m}^{-2} \mathrm{~d}^{-1}\right)$

$P_{0, x} \quad=$ length of wetted perimeter at the water-sediment interface ( $z=0$ from the perspective of the sediment) at location $x(m)$

At time $t$.
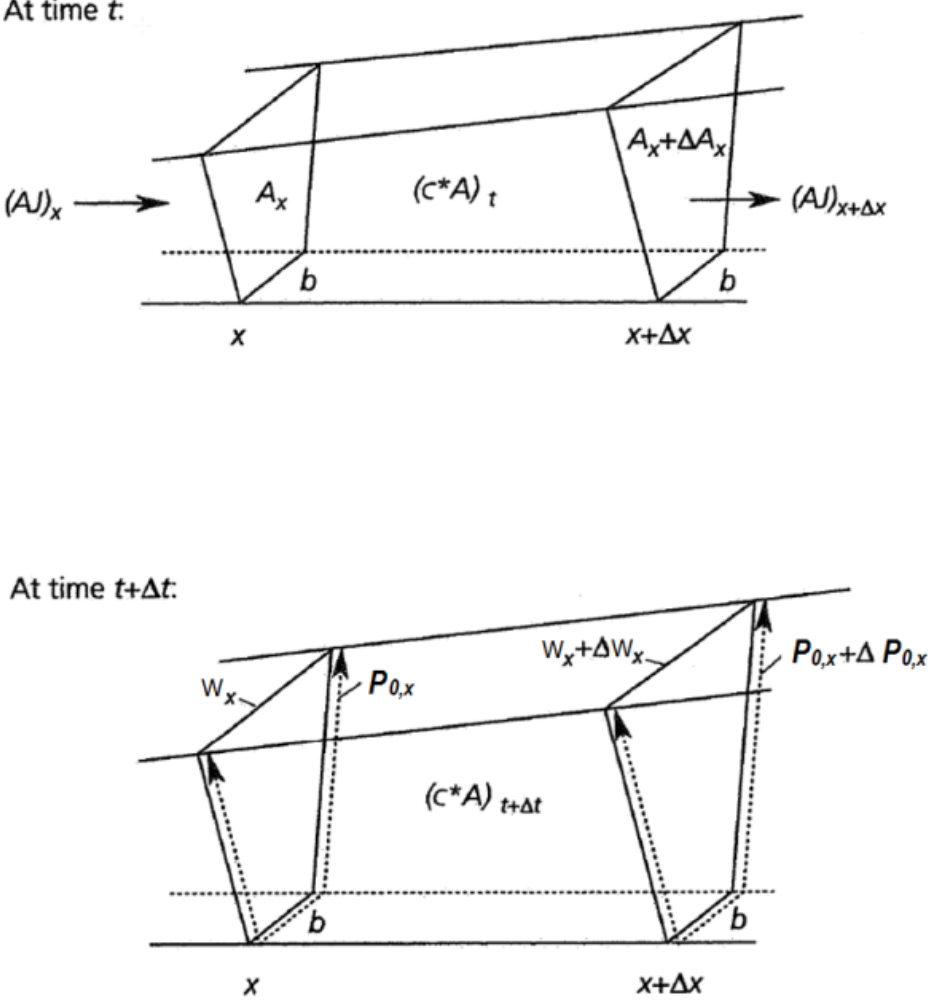

Figure 11 Mass balance at times $t$ and $t+\Delta t$ in the water body; $C^{*} A$ is the mass above a unit of length $\Delta x$; note that $A, P_{0, x}$ and $W_{x}$ at $t+\Delta t$ are different from those at time $t$. 
Note that for the exchange between the water layer and sediment the symbol $P_{\text {wet }}$ has been used for exchange of water, and the symbols $P_{0}, P_{\mathrm{z}}$ and $P_{\mathrm{D}}$ are used for the exchange of pesticide.

Only the length of the waterbody and the width of the waterbody bottom, $b$, are constant values. All other parameters shown in Figure 11 can change in time, and can vary along the length of the waterbody.

\subsubsection{Conservation equation}

The mass conservation equation for the pesticide in the water layer is:

$\frac{\partial\left(c_{w}^{*} \cdot A\right)}{\partial t}=-\frac{\partial\left(A \cdot J_{w}\right)}{\partial x}-R_{t, p} \cdot A+J_{a} W-J_{s} \cdot P_{0}$

with:

$R_{\mathrm{t}, \mathrm{p}}=$ rate of transformation of substance in the water layer (i.e. in water phase, sorbed to suspended solids and sorbed to macrophytes) $\left(\mathrm{kg} \mathrm{m}^{-3} \mathrm{~d}^{-1}\right)$

$\mathrm{J}_{\mathrm{a}}=\operatorname{areic}^{7}$ mass flux of substance across the water-air interface $\left(\mathrm{kg} \mathrm{m}^{-2} \mathrm{~d}^{-1}\right)$ [the flux is negative in upward direction]

$J_{\mathrm{s}} \quad=$ areic mass flux of substance across the water-sediment interface $\left(\mathrm{kg} \mathrm{m}^{-2} \mathrm{~d}^{-1}\right)$

$P_{0} \quad=$ length of wetted perimeter at depth $z=0$, via which exchange between water and sediment occurs $(m)$

For each of the transformation products an extra term is added to the right-hand side of Eq. (20):

$\frac{\partial\left(c_{w}^{*} \cdot A\right)}{\partial t}=-\frac{\partial\left(A \cdot J_{w}\right)}{\partial x}-R_{t, p} \cdot A+J_{a} \cdot W-J_{s} \cdot P_{0}+R_{f, p}$

with:

$R_{\mathrm{f}, \mathrm{p}} \quad=$ rate of formation of substance in the water layer $\left(\mathrm{kg} \mathrm{m}^{-3} \mathrm{~d}^{-1}\right)$

The total pesticide concentration in the water layer, $c_{w}{ }^{*}$, is given by:

$c_{w}^{*}=c_{w}+\frac{m_{m p} \cdot P_{0}}{A} X_{m p}+m_{s S} X_{s S}$

with:

$m_{\mathrm{mp}} \quad=$ dry weight of macrophytes per area of sediment $\left(\mathrm{kg} \mathrm{m}^{-2}\right)$

$X_{\mathrm{mp}} \quad=$ content of substance sorbed to macrophytes $\left(\mathrm{kg} \mathrm{kg}^{-1}\right)$

$m_{\mathrm{ss}} \quad=$ mass concentration of suspended solids in the water layer $\left(\mathrm{kg} \mathrm{m}^{-3}\right)$

$c_{\mathrm{w}} \quad=$ mass concentration of substance in the water phase $\left(\mathrm{kg} \mathrm{m}^{-3}\right)$

\subsection{Sediment}

\subsubsection{System description - general}

In the sediment the substance is subject to the following processes (see Figure 10).

- Advection, dispersion and diffusion in z-direction.

- Exchange with the water layer by advection and diffusion.

- Sorption to the solid phase of the sediment.

- Transformation, described as overall transformation of substance dissolved and sorbed to the solid phase of the sediment.

\footnotetext{
${ }^{7}$ areic means that it is divided by the surface area concerned.
} 
In small waterbodies (beside the bottom of the waterbody) the walls account for an important part of the total exchange area between water and sediment. Therefore the wetted perimeter instead of the bottom width is modelled as the exchange area.

Perpendicular to the wetted perimeter, the substance is transported between water layer and sediment. Per unit of length in the direction of flow this transport takes place through an area $P_{0} \cdot 1$ $\left(\mathrm{m}^{2}\right)$.

The perimeter at the water-sediment interface, $P_{0}$, is given by:

$P_{0}=b+2 h_{w} \sqrt{s_{1}^{2}+1}$

with:

$h_{\mathrm{w}} \quad=$ depth defining perimeter for exchange between water and sediment $(\mathrm{m})$

At distance $z$ from the water-sediment interface transport in the sediment takes place through the area $P_{\mathrm{z}} \cdot 1$ (see Figure 12 and Figure 14), where

$P_{z}=b+2 z \cdot \tan \left(\frac{1}{2} \beta\right)+2\left(h_{w}+z\right) \sqrt{s_{1}^{2}+1}$

with:

$P_{\mathrm{z}} \quad=$ length of perimeter at depth $z$ from the water-sediment interface $(\mathrm{m})$

$\beta \quad=\arctan \left(1 / s_{1}\right)(\mathrm{rad})$

$z \quad=$ depth in the sediment from the water-sediment interface to area concerned $(\mathrm{m})$

Transport perpendicular to the wetted perimeter occurs in two dimensions, the $z$-direction and the $y$ direction. It has been assumed that the substance is ideally mixed horizontally (i.e. y-direction) in the sediment. Furthermore, it has been assumed that transport in the $x$-direction in the sediment is so small that it can be neglected. Hence the three-dimensional transport has been simplified to the onedimensional transport in the $z$-direction. This implies also that transport 'around corners' is neglected; the waterbody walls are straightened and the flow pattern has been simplified to one-dimensional transport in a widening sediment column.

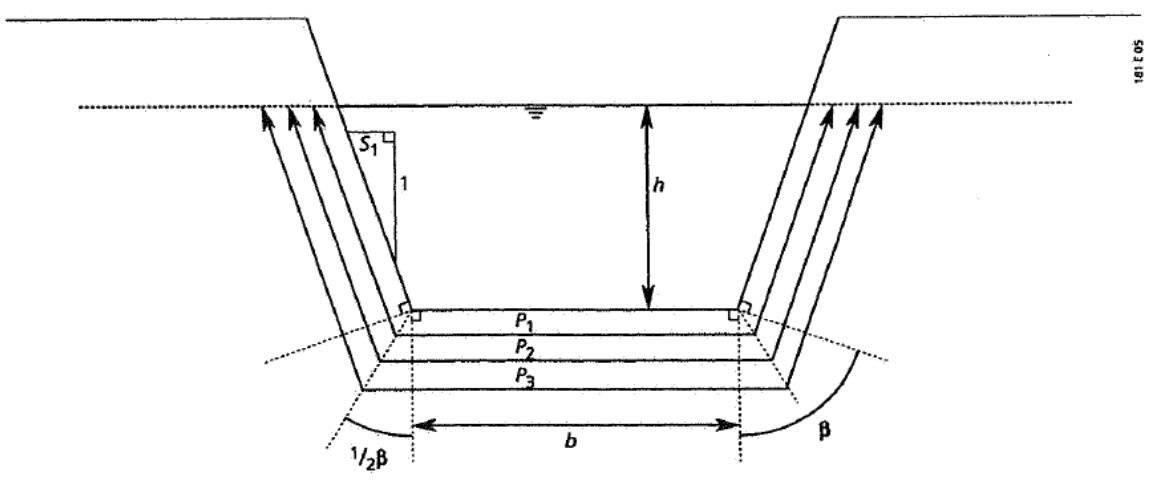

Figure 12 Cross section of a waterbody and the sediment below this body with the shape of stacked trapezia (in the figure it is assumed that $h_{w}=h$ ). The lines in the sediment are the perimeters whose length increases with depth in the sediment. 


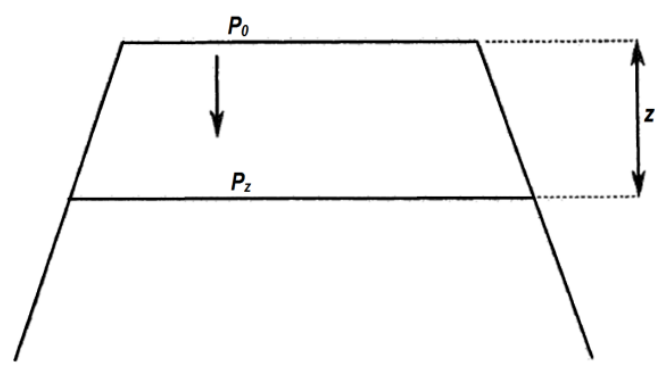

Figure 13 The sediment subsystem simplified to one dimension.

Hence the assumption is that the two-dimensional transport can be calculated by means of a onedimensional description of mass transport in a sediment column widening with depth. This onedimensional description has been applied to the sediment subsystem situated below the exchange area between water layer and sediment; this area has a constant size. The assumption has been made that the size of the exchange area is constant, and does not depend on the varying water level in the waterbody.

The size of the exchange area per unit of length in the $x$ direction equals the wetted perimeter of the waterbody corresponding to a particular water level $h_{\mathrm{w}}$ (Figure 14). This fixed value of $h_{\mathrm{w}}$ can be for instance the minimal water level occurring in the waterbody. The mass transport thus takes place in a trapezium-shaped sediment column underneath the area of constant size $P_{0}$, per unit of length.

Note that when $h_{\mathrm{w}}=0$ the perimeter still increases with depth (see Eq. (24)), which can be seen in Figure 14. For simulation of water-sediment studies (e.g. Ter Horst \& Koelmans, 2016) or mesocosms with vertical artificial walls (e.g. Deneer et al., 2016) this is not realistic because sediment is only present directly below the water layer. For these types of systems Eq. (24) has been simplified to:

$P_{z}=b$

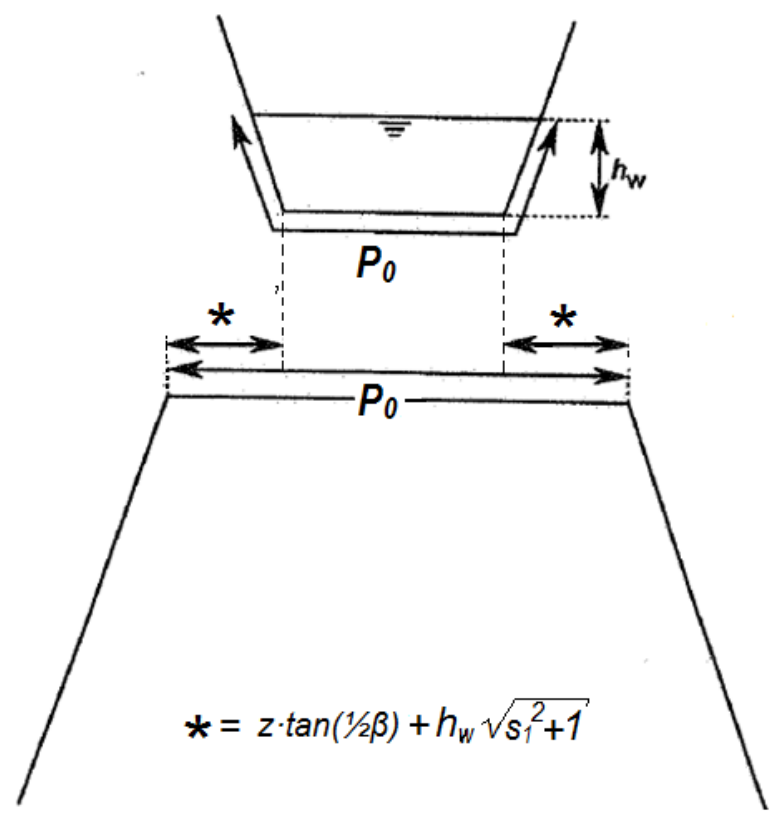

Figure 14 The sediment subsystem situated below an area of constant size, through which exchange of pesticide between water layer and sediment occurs.

The mass balance for the substance in the sediment is depicted in Figure 15 


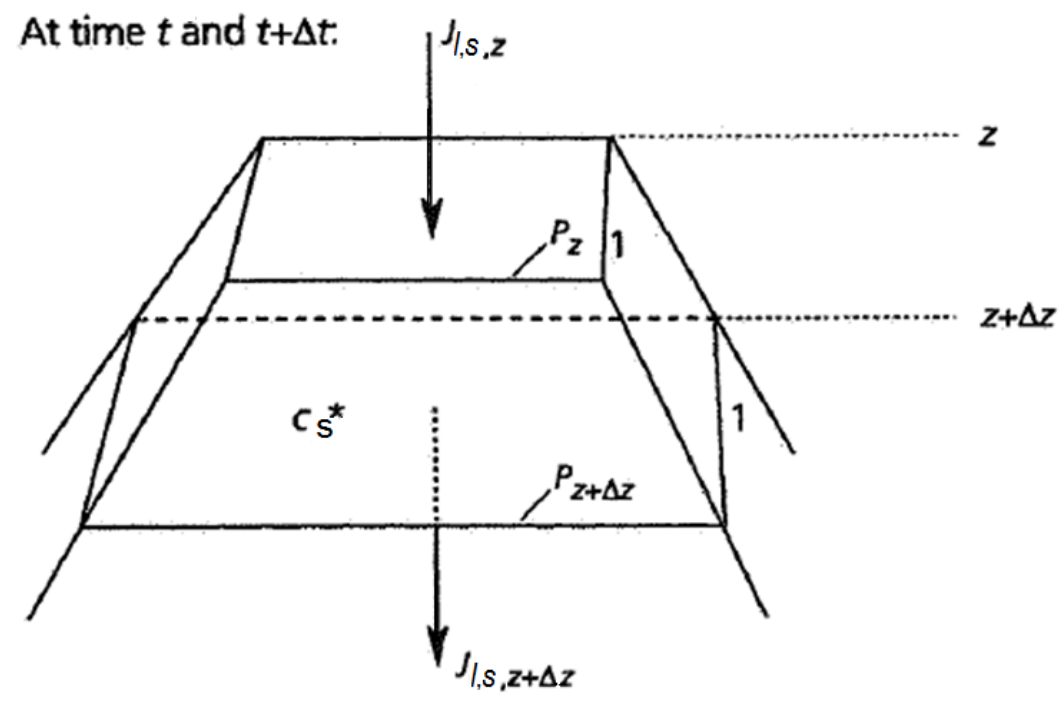

Figure 15 Mass balance for the sediment subsystem. $c_{s}{ }^{*}$ is the mass above a unit of length $\Delta x$

\subsubsection{Conservation equation}

The mass conservation equation for the pesticide in sediment is:

$P \frac{\partial c_{s}^{*}}{\partial t}=\frac{\partial\left(P \cdot J_{l, s}\right)}{\partial z}-R_{s, t, p} \cdot P$

with:

$c_{s}^{*} \quad=$ mass concentration in the sediment $\left(\mathrm{kg} \mathrm{m}^{-3}\right)$

$z \quad=$ depth in sediment $(\mathrm{m})$

$J_{l, s}=$ areic mass flux by advection, dispersion and diffusion in the liquid phase of the sediment $\left(\mathrm{kg} \mathrm{m}^{-2} \mathrm{~d}^{-1}\right)$

$R_{s, t, p}=$ rate of transformation of parent substance in the sediment $\left(\mathrm{kg} \mathrm{m}^{-3} \mathrm{~d}^{-1}\right)$

$P \quad=$ length of perimeter $(\mathrm{m})$

For each of the transformation products an extra term is added to the right-hand side of Eq. (26) which results in:

$P \frac{\partial c_{s}^{*}}{\partial t}=\frac{\partial\left(P \cdot J_{l, s}\right)}{\partial z}-R_{s, t, p} \cdot P+R_{s, f, p} \cdot P$

with:

$R_{\mathrm{s}, \mathrm{f}, \mathrm{p}}=$ rate of formation of parent substance in the sediment $\left(\mathrm{kg} \mathrm{m}^{-3} \mathrm{~d}^{-1}\right)$

The total pesticide concentration in sediment, $c_{s}{ }^{*}$, is given by:

$c_{s}^{*}=\varepsilon c_{l, s}+\rho_{b} X_{s}$

with:

$\varepsilon \quad=$ volume fraction of pore water $(-)$

$c_{\mathrm{l}, \mathrm{s}}=$ mass concentration of substance in liquid phase in the sediment $\left(\mathrm{kg} \mathrm{m}^{-3}\right)$

$\rho_{\mathrm{b}} \quad=$ bulk density of dry sediment, i.e. volumic mass of dry sediment material $\left(\mathrm{kg} \mathrm{m}^{-3}\right)$

$X_{s} \quad=$ mass sorbed to sediment $\left(\mathrm{kg} \mathrm{kg}^{-1}\right)$. 


\section{$5 \quad$ Pesticide entry routes}

\section{$5.1 \quad$ Introduction}

In this chapter we discuss pesticide entry routes entering the waterbody at the boundaries and entry routes representing lateral entries in the waterbody. The entries at the boundaries are discussed in Section 5.2. Lateral entries can be divided in to four types of inputs. Not all four types of input are operational in TOXSWA 3.3, however for all four types the mathematical elaboration for the generic case of the input type is given in Annex 2 . This is not given for the sediment because its elaboration is analogous to that of the water layer.

For those lateral input entries that are operational in TOXSWA the specific implementation for the corresponding entry route(s) is given in Sections $5.3-5.5$ (including the mass conservation equation for the pesticide).

\subsection{Entry routes at the boundaries}

\subsubsection{Entries at the upper boundary}

Water entering at the upper boundary $(x=0)$ of the waterbody may contain pesticide. The pesticide is transported into the waterbody. Here only advection is considered:

$J_{w}=Q_{u} c_{u}^{*}$

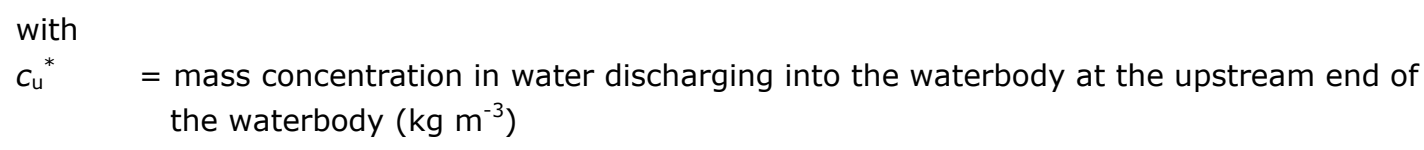

\subsubsection{Into sediment via upward seepage}

When upward seepage occurs (hence $q_{F, s}<0$ ) at the lower end of the sediment (lower boundary) pesticide mass may be transported into the sediment. Here only advection is considered:

$J_{l, s}=\frac{w_{F}}{P_{D}} q_{F, s} c_{s p g}$

with:

$c_{\text {spg }}=$ mass concentration in seepage water $\left(\mathrm{kg} \mathrm{m}^{-3}\right)$

$P_{\mathrm{D}} \quad=$ perimeter at lower boundary of sediment, at depth $z=D(\mathrm{~m})$

\subsection{Lateral entries in the waterbody - type of inputs}

Lateral entries of pesticides into the waterbody are inputs that are included as options in the conservation equation.

In TOXSWA 3.3, the mass conservation equation for the pesticide in the water layer that is extended with two types of entries of pesticide is: 
$\frac{\partial\left(c_{w}^{*} A\right)}{\partial t}=-\frac{\partial\left(A \cdot J_{w}\right)}{\partial x}-R_{t, p} A+J_{a} W_{x}-J_{S} P_{0}+S_{p, d} A+S_{c, d} A$

with:

$S_{\mathrm{p}, \mathrm{d}}(t, x)=$ distributed pulse input $\left(\mathrm{kg} \mathrm{m}^{-3} \mathrm{~d}^{-1}\right)$

$S_{c, d}(t, x)=$ distributed source with continuous input $\left(\mathrm{kg} \mathrm{m}^{-3} \mathrm{~d}^{-1}\right)$

Distributed pulse type inputs are released into the water layer in an infinitesimally small period of time, so a certain mass of substance is released into the water layer (e.g. spray drift event).

Distributed sources with a continuous input are released into the waterbody as flux, i.e. mass released during a time interval as a rate (e.g. series of discharging drains in an agricultural field).

The mass conservation equation for the pesticide in the sediment that is extended with one type of entry of pesticide is:

$P \frac{\partial c_{s}^{*}}{\partial t}=\frac{\partial\left(P \cdot J_{l, s}\right)}{\partial z}-R_{s, t, p} P+S_{c, d} P$

with:

$S_{c, d}(t, z)=$ distributed source with continuous input $\left(\mathrm{kg} \mathrm{m}^{-3} \mathrm{~d}^{-1}\right)$

Considering the sediment the distributed source with continuous input (e.g. erosion) has been implemented in TOXSWA.

\subsection{Spray drift}

Spray drift is modelled as a distributed pulse input. It is assumed that the supplied lineic mass of substance $m_{\llcorner}\left(\mathrm{kg} \mathrm{m}^{-1}\right)$ is instantaneously and ideally mixed in the water layer at the time of release. The mathematical elaboration for the generic case of a distributed pulse input is given in Annex 2 (Section A2.3).

The equations (82) and (85) (both equations can be found in Annex 2) have been implemented in TOXSWA for the simulation of spray drift entry, where

$m_{L}=W \cdot m_{\text {drift }}$

with

$m_{\mathrm{L}} \quad=$ lineic mass of substance $\left(\mathrm{kg} \mathrm{m}^{-1}\right)$

$m_{\text {dritt }} \quad=$ spray drift mass deposited at the water layer $\left(\mathrm{kg} \mathrm{m}^{-2}\right)$

\subsection{Drainage, runoff and erosion}

Releases via drainage and runoff are examples of continuous distributed releases into the water layer. Release via erosion is an example of a continuous distributed release into the sediment. The mathematical elaboration for the generic case of a continuous distributed input in the water layer is given in Annex 2 (Section A2.5).

\subsubsection{Water layer: drainage and runoff}

Drainage and runoff inputs according to Eq. (88) (Annex 2) are modelled in TOXSWA for the water layer with 
$m_{L T}(t, x)=q_{F} \cdot w_{F} c_{w, F}$

with

$C_{W, F}=$ concentration in water from lateral discharge, by drainage or runoff $\left(\mathrm{kg} \mathrm{m}^{-3}\right)$

$m_{L T} \quad=$ lineic mass of substance $\left(\mathrm{kg} \mathrm{m}^{-1} \mathrm{~d}^{-1}\right)$

\subsubsection{Sediment: erosion}

Erosion inputs according to Eq. (89) (Annex 2) are modelled in TOXSWA for the sediment with

$m_{L T}(t, z)=J_{e r} w_{e r}$

with

$J_{\text {er }} \quad=$ mass flux of substance associated with eroded soil $\left(\mathrm{kg} \mathrm{m}^{-2} \mathrm{~d}^{-1}\right)$

$w_{\mathrm{er}} \quad=$ width of the adjacent field of which soil is eroded $(\mathrm{m})$

The increase in total sediment concentration by entry of eroded soil is based on the assumption that the waterbody receives the mass flux of substance in eroded sediment from a strip with width $F_{\text {er }}$ from the adjacent field. It is furthermore assumed that this mass flux is instantaneously distributed over a top layer of the sediment with thickness $z_{m i x}$, in such a way that the increase of the concentrations is constant over $z_{\text {mix }}$.

\subsection{Considerations}

The Greenhouse Emission Model (GEM) software tool uses TOXSWA 3.3 in conjunction with other models (e.g. PEARL, SEM) and Dutch greenhouse horticulture exposure scenarios (Wipfler et al., 2015a; Wipfler et al., 2015b) for calculation of pesticide exposure in watercourses adjacent a greenhouse. A release from a water basin of a greenhouse, adding water with a constant concentration of the substance to the adjacent watercourse is an example of a continuous point release. However this type of a lateral entry is not implemented in TOXSWA 3.3. Therefore, for simulating the water and substance inputs from the greenhouses to the adjacent watercourse in the Dutch greenhouse scenarios the following approach was adopted. Discharge from greenhouses to the adjacent watercourse was simulated as a point source at the upper boundary of the watercourse by adding the discharge volume flux to the water flux entering the water layer at the upper boundary of the water body. The pesticide mass that is discharged by the greenhouse was simulated as an incoming mass flux at the upper boundary of the watercourse (Wipfler et al., 2015a). 



\section{$6 \quad$ Pesticide process of partitioning}

\subsection{Water layer}

\section{Sorption to suspended solids}

The sorption of pesticides to suspended solids is instantaneous (equilibrium sorption), described with a Freundlich sorption isotherm:

$X_{s S}=K_{F, s s} c_{S s, r}\left(\frac{c_{w}}{c_{S s, r}}\right)^{N_{s s}}$

with:

$X_{\mathrm{ss}} \quad=$ mass content sorbed to suspended solids $\left(\mathrm{kg}^{-1} \mathrm{~kg}^{-1}\right)$

$K_{\mathrm{F}, \mathrm{ss}} \quad=$ Freundlich coefficient for sorption to suspended solids $\left(\mathrm{m}^{3} \mathrm{~kg}^{-1}\right)$

$c_{\mathrm{ss}, \mathrm{r}}=$ reference concentration in the liquid phase for sorption to suspended solids $\left(\mathrm{kg} \mathrm{m}^{-3}\right)$

$N_{\mathrm{ss}} \quad=$ Freundlich exponent for sorption to suspended solids (-)

Using the Freundlich sorption equation, the partitioning between the solid and liquid phases is dependent on concentration $c_{w}$. Then $c_{w}$ cannot be expressed in explicit way as a function of the other quantities. The implicit equation has to be solved by iteration, as described in Annex 3.

If the pesticide is mainly sorbed to the organic matter of the suspended solids, the Freundlich coefficient for sorption to suspended solids, $K_{\mathrm{F}, \mathrm{ss}}$, is calculated from

$K_{F, s s}=m_{o m, s s} K_{o m, s s}$

with:

$m_{\mathrm{om}, \mathrm{ss}}=$ mass fraction of organic matter in suspended solids $\left(\mathrm{kg}^{-1} \mathrm{~kg}^{-1}\right)$

$K_{\mathrm{om}, \mathrm{ss}}=$ coefficient of equilibrium sorption on organic matter in suspended solids $\left(\mathrm{m}^{3} \mathrm{~kg}^{-1}\right)$

\section{Sorption to macrophytes}

The sorption of pesticides to macrophytes is instantaneous (equilibrium sorption), described with a linear sorption isotherm:

$X_{m p}=K_{m p} c_{w}$

with:

$K_{\mathrm{mp}}=$ distribution coefficient for substance between macrophytes and water, i.e. the slope of the linear sorption isotherm on the mass of dry macrophytes $\left(\mathrm{m}^{3} \mathrm{~kg}^{-1}\right)$

\subsection{Sediment}

\section{Sorption to sediment}

The sorption of pesticides to sediment is instantaneous (equilibrium sorption), described with a Freundlich sorption isotherm:

$X_{s}=K_{F, s} c_{s, r}\left(\frac{c_{l, s}}{c_{s, r}}\right)^{N_{s}}$ 
with:

$K_{\mathrm{F}, \mathrm{S}} \quad=$ Freundlich coefficient for sorption to sediment $\left(\mathrm{m}^{3} \mathrm{~kg}^{-1}\right)$

$C_{s, r} \quad=$ reference concentration in the liquid phase for sorption to the sediment $\left(\mathrm{kg} \mathrm{m}^{-3}\right)$

$N_{s} \quad=$ Freundlich exponent for sorption to sediment $(-)$

Using the Freundlich sorption equation, the partitioning between the solid and liquid phases is dependent on concentration $c_{1, s}$. Then $c_{1,5}$ cannot be expressed in explicit way as a function of the other quantities. The implicit equation has to be solved by iteration, as described in Annex 2.

If the pesticide is mainly sorbed to the organic matter of the sediment, the Freundlich coefficient for sorption to sediment, $K_{\mathrm{F}, \mathrm{s}}$, is calculated from

$K_{F, s}=m_{o m, s} K_{o m, s}$

with:

$m_{\mathrm{om}, \mathrm{s}}=$ mass fraction of organic matter in sediment $\left(\mathrm{kg}^{-1} \mathrm{~kg}^{-1}\right)$

$K_{\mathrm{om}, \mathrm{s}}=$ coefficient of equilibrium sorption on organic matter in sediment $\left(\mathrm{m}^{3} \mathrm{~kg}^{-1}\right)$ 


\section{$7 \quad$ Pesticide transport and emission}

\subsection{Water layer}

\subsubsection{Transport by advection and dispersion}

The flux $J_{w}$ of the conservation equation describes the transport of the substance, both dissolved in water and sorbed to the suspended solids. It consists of an advective and a dispersive component (which are assumed identical for the dissolved and sorbed substance).

$J_{w}=u\left(c_{w}+m_{s S} X_{s S}\right)-E_{p h y s} \frac{\partial\left(c_{w}+m_{s S} X_{S S}\right)}{\partial x}$

with:

$u=$ flow velocity of the water $\left(\mathrm{m} \mathrm{d}^{-1}\right)$

$E_{\text {phys }}=$ longitudinal dispersion coefficient (in the direction of flow) $\left(\mathrm{m}^{2} \mathrm{~d}^{-1}\right)$

The term $\partial\left(A J_{w}\right) / \partial x$ in the conservation equation equals

$\frac{\partial\left(A\left[u_{x}\left(c_{w}+m_{S S} X_{S S}\right)-E_{p h y s} \frac{\partial\left(c_{w}+m_{S S} X_{S S}\right)}{\partial x}\right]\right)}{\partial x}=\frac{\partial\left(Q\left(c_{w}+m_{S S} X_{S S}\right)-A E_{p h y s} \frac{\partial\left(c_{w}+m_{S S} X_{S S}\right)}{\partial x}\right)}{\partial x}$

in which

$Q=A \cdot u$

Longitudinal dispersion, $E_{\text {phys, }}$ is calculated using Fischer's equation (Fischer et al., 1979):

$E_{\text {phys }}=c_{F} \frac{u^{2} W^{2}}{h \cdot u^{*}}$

with:

$E_{\text {phys }} \quad=$ physical dispersion coefficient $\left(\mathrm{m}^{2} \mathrm{~d}^{-1}\right)$

$u^{*} \quad=$ shear velocity $\left(\mathrm{m} \mathrm{d}^{-1}\right)$

$c_{F} \quad=$ coefficient $(-)$

Note that in Fischers' original equation $u$ reads $\bar{u}$ (average cross-sectional flow velocity in $\mathrm{m} \mathrm{d}^{-1}$ ). In TOXSWA the water layer is assumed to be ideally mixed horizontally and vertically, therefore $\bar{u}$ can be replaced by $u$.

The shear velocity is calculated as (Fischer et al., 1979):

$u^{*}=0.1 u$

\subsubsection{Transport by advection to downstream waterbody}

Water discharging at the downstream end (lower boundary) of the waterbody transports the pesticide out of the waterbody. Here only advection is considered: 
with

$Q_{\text {out }} \quad=$ discharge of water at the downstream end of the waterbody $\left(\mathrm{m}^{3} \mathrm{~d}^{-1}\right)$

\subsection{Sediment}

\subsubsection{Transport by advection, dispersion and diffusion}

In the pore water the substance is transported by advection, dispersion. This flux, $\mathrm{J}_{1,5}$, is described by:

$J_{l, s}=\frac{w_{F}}{P} \cdot q_{F, s} \cdot c_{l, s}-\varepsilon\left(E_{l, s}+D_{l, s}\right) \frac{\partial c_{l, s}}{\partial z}$

with

$E_{1,5} \quad=$ dispersion coefficient in pore water $\left(\mathrm{m}^{2} \mathrm{~d}^{-1}\right)$

$D_{1,5} \quad=$ diffusion coefficient in pore water $\left(\mathrm{m}^{2} \mathrm{~d}^{-1}\right)$

The dispersion coefficient is taken to be proportional to the volume flux of the liquid phase:

$E_{l, s}=L_{d i s}|\omega|$

with:

$L_{\text {dis }} \quad=$ dispersion length $(\mathrm{m})$

$\omega \quad=$ average flow velocity of pore water (i.e. $\left.W_{F} q_{F, s} / P \mathcal{E}\right)\left(\mathrm{m} \mathrm{d}^{-1}\right)$

The diffusion coefficient of the substance in the liquid phase of the sediment, $D_{\mathrm{l}, \mathrm{s}}$, is calculated as:

$D_{l, s}=\lambda \cdot D_{w}$

with:

$\lambda \quad=$ relative diffusion coefficient (or tortuosity) $(-)$

$D_{\mathrm{w}} \quad=$ diffusion coefficient in water $\left(\mathrm{m}^{2} \mathrm{~d}^{-1}\right)$

A special problem may occur in the sediment. Very sharp concentration gradients may exist here. The magnitude (and direction) of the diffusive and dispersive fluxes are calculated with the aid of concentration gradients (see e.g. Eq. (47)). Dispersion of the substance originates in the unequal flow velocities of pore water (i.e. in the velocity distribution) and is thus caused by advection. If then logically follows that the combined material flux resulting from advection and its ensuing dispersion, should have the same direction as the advection. Otherwise the effect would cancel out its cause (Bolt, 1979, pp. 301 and 346).

Figure 16 shows the four possible situations, occurring in the sediment. In situations 1 and 3 , the advective and dispersive fluxes have the same direction, so the above mentioned problem does not arise. In situation 2 as well in situation 4, the advective and dispersion fluxes have opposite directions, so it is possible that the dispersive flux cancels out tor even exceeds the advective flux. This is prevented as by the procedure described below. 

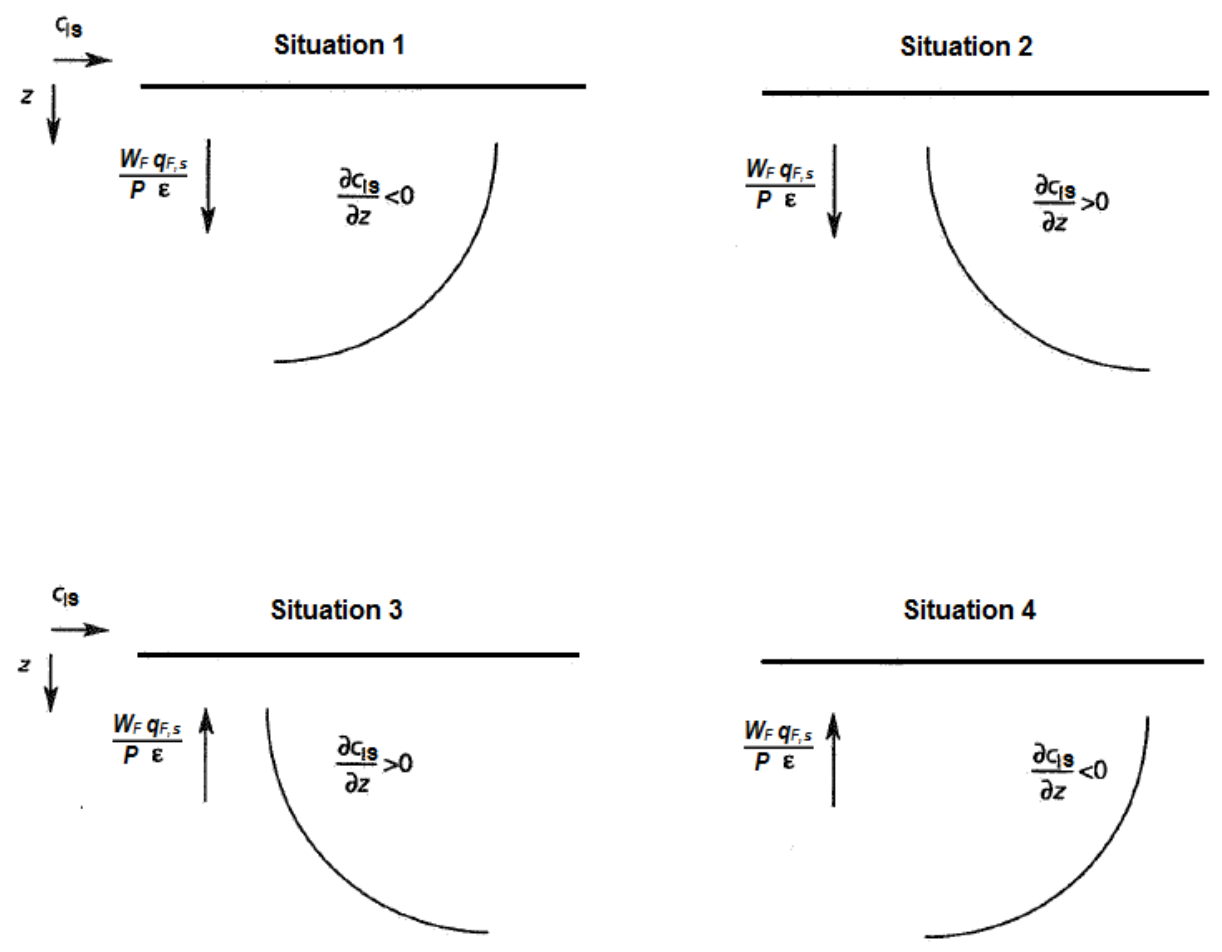

Situation 4

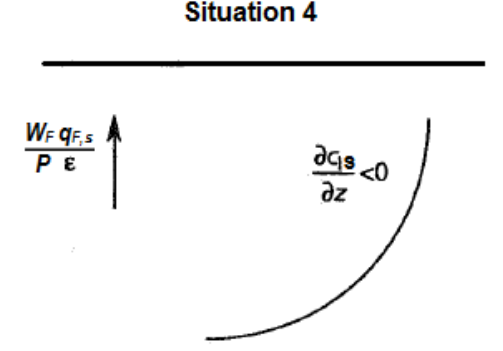

Figure 16 Four situations in the sediment, depicting the possible combinations of the directions of the advection flow (i.e. $W_{F} q_{F, s} / P \varepsilon$ ) and the concentration gradient ( $\left.\partial c_{l, s} / \partial z\right)$.

For situation 2:

$q_{\mathrm{F}, \mathrm{S}}>0$ and $\partial\left(c_{\mathrm{l}, \mathrm{s}} / \partial z>0\right.$.

According to Eq. (48), with $q>0$ :

$E_{l, s}=L_{d i s} \frac{w_{F} q_{F, s}}{P \varepsilon}$

The dispersive flux should not exceed the advective flux, hence:

$\left|\frac{W_{F}}{P} q_{F, s} c_{l, s}\right|>\left|\varepsilon E_{l, s} \frac{\partial c_{l, s}}{\partial z}\right|$

giving ( $q_{F, s}$ is positive):

$$
c_{l, s}-L_{d i s} \frac{\partial c_{l, s}}{\partial z}>0
$$

For situation 4:

$q_{\mathrm{F}, \mathrm{s}}<0$ and $\partial\left(c_{\mathrm{l}, \mathrm{s}} / \partial z<0\right.$.

According to Eq. (48), with $q_{F, s}<0$ :

$E_{l, s}=L_{d i s} \frac{-w_{F} q_{F, s}}{P \varepsilon}$

The dispersive flux should not exceed the advective flux, hence: 
$\left|\frac{W_{F}}{P} q_{F, s} c_{l, s}\right|>\left|\varepsilon E_{l, s} \frac{\partial c_{l, s}}{\partial z}\right|$

giving $\left(-q_{\mathrm{F}, \mathrm{S}}\right.$ is positive):

$$
c_{l, s}-L_{d i s} \frac{\partial c_{l, s}}{\partial z}>0
$$

This means that the dispersive flux is smaller than the advective flux if the following conditions are fulfilled:

for $q_{F, s}>0$, and $\frac{\partial c_{l, s}}{\partial z}>0: \quad c_{l, s}-L_{d i s} \frac{\partial c_{l, s}}{\partial z}>0$

and

for $q_{F, s}<0$, and $\frac{\partial c_{l, s}}{\partial z}<0: \quad c_{l, s}+L_{d i s} \frac{\partial c_{l, s}}{\partial z}>0$

When the dispersion flux would exceed the advective flux, it has been assumed that the dispersive flux will only cancel out the advective flux. Hence, only the diffusive flux is left in these cases (see also De Heer, 1979, p. 122).

\subsubsection{Transport by advection to soil}

The downward water flow $\left(q_{\mathrm{F}, \mathrm{s}}>0\right)$ from the lower end of the simulated sediment system transports the pesticide in the (saturated) soil. Here only advection is considered:

$J_{l, s}=\frac{w_{F}}{P_{D}} \cdot q_{F, s} \cdot c_{l, s}$

If there is upward seepage from the soil below the waterbody, pesticide mass can enter the sediment. This is described in Section 5.2.2.

\subsection{Water-sediment interface: advection and diffusion}

The mass flux at the water-sediment interface is composed of an advective and diffusive component (there is no dispersive component across the interface), hence for the water layer:

$J_{s}=\frac{w_{F}}{P_{0}} \cdot q_{F, s} \cdot c_{l, s}-\varepsilon D_{l, s} \frac{\partial c_{l, s}}{\partial z}$

It is assumed that diffusion across the water-sediment interface is rapid compared to diffusion in sediment. This implies that the interface resistance is negligible and that the mass concentration of the substance in the water layer equals that in the outer sediment pores, hence $c_{\mathrm{w}}=c_{1, \mathrm{~s}}($ at $z=0$ ).

The advective component of the exchange flux (first term) consists either of a supply of water with substance towards the waterbody due to drainage the neighbouring field (entering via the bottom of the waterbody) or infiltrating water from the water towards the neighbouring fields (leaving via the bottom of the waterbody).

For the sediment the mass flux is calculated by: 
$J_{l, s}=J_{s}$

The condition at the surface of the sediment is that the concentration in the pore water in the sediment is equal to the concentration in the water, hence. $c_{\mathrm{l}, \mathrm{s}}($ at $z=0)=c_{\mathrm{w}}$.

\subsection{Volatilization from the water layer}

The exchange flux of the pesticide between the water layer and the atmosphere is described by:

$J_{a}=-k_{t, l}\left(c-\frac{c_{a}}{K_{H}}\right)$

with:

$k_{\mathrm{t}, \mathrm{l}}=$ overall transfer coefficient of substance in the liquid phase $\left(\mathrm{m} \mathrm{d}^{-1}\right)$

$c_{a} \quad=$ mass concentration of substance in the $\operatorname{air}\left(\mathrm{kg} \mathrm{m}^{-3}\right)$

$K_{\mathrm{H}} \quad=$ Henry coefficient $(-)$

in which

$\frac{1}{k_{t, l}}=\frac{1}{k_{l}}+\frac{1}{K_{H} \cdot k_{g}}$

with:

$k_{1}=$ exchange coefficient of substance in the liquid phase $\left(\mathrm{m} \mathrm{d}^{-1}\right)$

$k_{\mathrm{g}}=$ exchange coefficient of substance in the gas phase $\left(\mathrm{m} \mathrm{d}^{-1}\right)$

Henry's coefficient is calculated from Henry's law describing the partitioning of the pesticide between the liquid and the gas phase:

$K_{H}=\frac{c_{a}}{c_{I}}$

with:

$C_{\mathrm{I}} \quad=$ equilibrium mass concentration of substance at the water-gas interface in the water phase $\left(\mathrm{kg} \mathrm{m}^{-3}\right)$

Henry's coefficient is calculated form the ratio of saturated concentration in air and the solubility of the substance in water. The saturation concentration in air is calculated with Boyle's law for ideal gases, from the saturated vapour pressure. Both, vapour pressure and solubility in water are dependent on the temperature, so the same holds for the Henry coefficient. The Henry coefficient is calculated with:

$K_{H}=\frac{P_{s a t} \cdot M_{m}}{R \cdot T_{m}} \cdot \frac{1}{c_{s l b}}$

with:

$P_{\text {sat }} \quad=$ saturated vapour pressure of substance $(\mathrm{Pa})$

$M_{\mathrm{m}} \quad=$ molar mass $\left(\mathrm{kg} \mathrm{mol}^{-1}\right)$

$R \quad=$ universal gas constant $\left(\mathrm{J} \mathrm{mol}^{-1} \mathrm{~K}^{-1}\right)$

$T_{m} \quad=$ temperature at which the saturated vapour pressure, the solubility and the exchange coefficients are defined $(\mathrm{K})$

$c_{\mathrm{slb}}=$ solubility of substance in water $\left(\mathrm{kg} \mathrm{m}^{-3}\right)$ 
The temperature has much effect on the partitioning of the pesticide between the gas and liquid phases because the saturated vapour pressure and the solubility both are temperature dependent. Hence the effect of temperature on these properties should be considered.

\subsection{Effect of temperature}

\subsubsection{Saturated vapour pressure}

The effect of temperature on the saturated vapour pressure of the pesticide is described by the Van 't Hoff equation:

$$
P_{s a t}=P_{s a t, r} \exp \left[\frac{-\Delta H_{v}}{R}\left(\frac{1}{T}-\frac{1}{T_{r}}\right)\right]
$$

with:

$P_{\text {sat }, \mathrm{r}} \quad=$ saturated vapour pressure at reference temperature $(\mathrm{Pa})$

$\Delta H_{\mathrm{v}} \quad=$ molar enthalpy of vaporization $\left(\mathrm{J} \mathrm{mol}^{-1}\right)$

$T \quad=$ temperature $(\mathrm{K})$

$T_{\mathrm{r}} \quad=$ reference temperature $(\mathrm{K})$

The default value for $\Delta H_{\mathrm{v}}$ is taken to be $95 \mathrm{~kJ} \mathrm{~mol}^{-1}$, which is the average of available measurements as collected by Smit et al. (1997). Their data show a range from 58 to $146 \mathrm{~kJ} \mathrm{~mol}^{-1}$.

\subsubsection{Solubility}

The effect of temperature on the solubility of the pesticide $\left(c_{s / b}\right)$ is described by an equation similar to the Van 't Hoff equation:

$c_{s l b}=c_{s l b, r} \exp \left[\frac{-\Delta H_{d}}{R}\left(\frac{1}{T}-\frac{1}{T_{r}}\right)\right]$

with:

$c_{\mathrm{slb}, \mathrm{r}}=$ solubility at reference temperature $\left(\mathrm{kg} \mathrm{m}^{-3}\right)$

$\Delta H_{\mathrm{d}} \quad=$ molar enthalpy of dissolution in water $\left(\mathrm{J} \mathrm{mol}^{-1}\right)$

The default value for $\Delta H_{\mathrm{d}}$ is taken to be $27 \mathrm{~kJ} \mathrm{~mol}^{-1}$, which is the average of available measurements as collected by Smit et al. (1997). Their data show a range from -17 to $256 \mathrm{~kJ} \mathrm{~mol}^{-1}$. 


\section{$8 \quad$ Pesticide transformation processes}

\subsection{Metabolites: reaction scheme and kinetics}

The transformation of pesticides results in reaction products that can also have effects on the aquatic ecosystem. Therefore the formation and fate of transformation products are included in the model, in both the water layer and the sediment.

A pesticide may be subject to a chain of reaction in water, and/or in sediment, the so-called consecutive reactions:

Parent --> Product 1 ---> Product 2 ---> Product 3

Besides that, there are usually branches in the reaction scheme, representing the so-called simultaneous reactions. An example of a reaction scheme is presented in Figure 17.

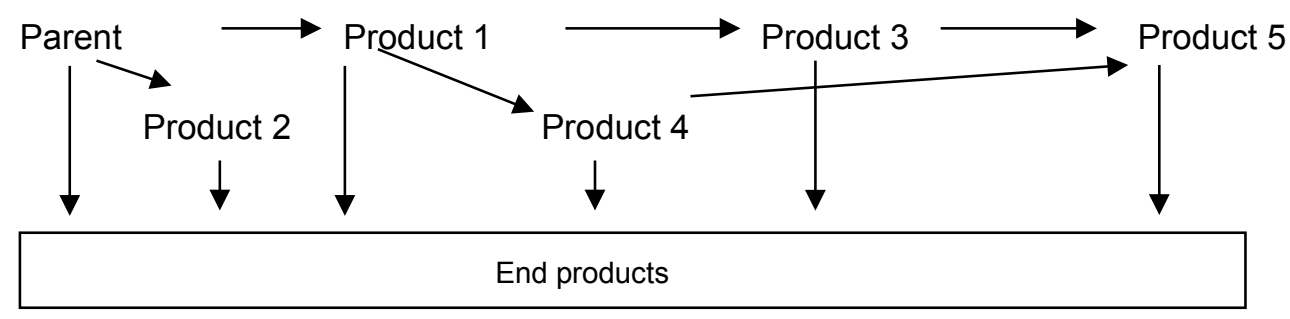

Figure 17 Example reaction scheme of parent decomposed into various metabolites. From Leistra et al. (2001).

The reaction scheme can be represented in a general way in a matrix, as shown in Table 1 . The matrix indicates that a compound is usually transformed into various products. Furthermore, a product may be formed from one or more precursor compounds. Various couples of substances are connected by a reaction, but other substances are not connected directly to each other.

\section{Table 1}

Example of a matrix which represents the reactions between the substances included in the reaction scheme of a pesticide. $0=$ no reaction. $\chi=$ molar fraction of a substance transformed into a specific product. From Leistra et al. (2001).

\begin{tabular}{|c|c|c|c|c|c|c|}
\hline Scenario & Parent & Product 1 & Product 2 & Product 3 & Product 4 & Product 5 \\
\hline Parent & 0 & $\chi_{p, 1}$ & $\chi_{p, 2}$ & 0 & 0 & 0 \\
\hline Product 1 & 0 & 0 & 0 & $\chi_{1,3}$ & $\chi_{1,4}$ & 0 \\
\hline Product 2 & 0 & 0 & 0 & 0 & 0 & 0 \\
\hline Product 3 & 0 & 0 & 0 & 0 & 0 & $\chi_{3,5}$ \\
\hline Product 4 & 0 & 0 & 0 & 0 & 0 & 4,5 \\
\hline Product 5 & 0 & 0 & 0 & 0 & 0 & 0 \\
\hline
\end{tabular}

The molar fractions $\chi$ are not restricted to the above-diagonal part of the matrix in the table. If Product 3 and Product 4 in the reaction scheme would be transformed partly to Product 2, the coefficients $\chi_{3,2}$ and $\chi_{4,2}$ would appear below the diagonal.

The rate of formation of reaction products can be described by first-order kinetics. For product 1 , formed from the parent compound: 
$R_{f, p, 1}=\chi_{p, 1} \frac{M_{1}}{M_{p}} R_{t, p}$

with:

$R_{\mathrm{t}, \mathrm{p}, 1}=$ rate of formation of product 1 from the parent compound $\left(\mathrm{kg} \mathrm{m}^{-3} \mathrm{~d}^{-1}\right)$

$\chi_{p, 1}=$ molar fraction of parent transformed to product $1(-)$

$M_{1} \quad=$ molar mass of product $1\left(\mathrm{~kg} \mathrm{~mol}^{-1}\right)$

$M_{\mathrm{p}} \quad=$ molar mass of parent compound $\left(\mathrm{kg} \mathrm{mol}^{-1}\right)$

For the transformation of product 1 :

$R_{t, 1}=k_{1} c_{1}^{*}$

with:

$R_{t, 1}=$ rate of transformation of the product $1\left(\mathrm{~kg} \mathrm{~m}^{-3} \mathrm{~d}^{-1}\right)$

$k_{1}=$ rate coefficient for transformation of product $1\left(\mathrm{~d}^{-1}\right)$

$\mathrm{c}_{1}{ }^{*} \quad=$ mass concentration of product $1\left(\mathrm{~kg} \mathrm{~L}^{-3}\right)$

A similar equation holds for each of the reaction products of the reaction scheme.

\subsection{Water layer}

The transformation rate coefficient of the substance in the water layer, $k_{\mathrm{w}}$, is a measure of the (entire) transformation of the substance. The substance may be dissolved in water or it may be sorbed to suspended solids or to macrophytes. The three most important transformation processes in the water layer are photolysis, hydrolysis and biotic degradation (Thomann and Mueller, 1987). Photolysis depends mainly on the light intensity in the water layer, hydrolysis depends especially on the $\mathrm{pH}$ and also on temperature, and biotic degradation is mainly determined by the extent and type of microorganism community and temperature.

Transformation of the parent pesticide in water is described by the following first-order rate equation:

$R_{t, p}=k_{w} c_{w}^{*}$

with:

$k_{\mathrm{w}}=$ rate coefficient for transformation of the parent substance in water $\left(\mathrm{d}^{-1}\right)$

$c_{\mathrm{w}}{ }^{*}=$ mass concentration of parent pesticide in water $\left(\mathrm{kg} \mathrm{m}^{-3}\right)$

Similar rate equations are used for each transformation product.

\subsection{Sediment}

The transformation rate coefficient of the substance in the sediment, $k_{\mathrm{s}}$, is a measure of the entire transformation of the substance in pore water as well as in sorbed form. The main transformation processes in the sediment are hydrolysis and biodegradation.

Transformation of the parent pesticide in sediment is described by the following first-order rate equation:

$R_{s, t, p}=k_{s} c_{s}^{*}$ 
with:

$k_{\mathrm{s}}=$ rate coefficient for transformation of parent substance in sediment $\left(\mathrm{d}^{-1}\right)$

$c_{\mathrm{s}}{ }^{*} \quad=$ mass concentration of parent substance in sediment $\left(\mathrm{kg} \mathrm{m}^{-3}\right)$

Similar rate equations are used for each transformation product.

\subsection{Effect of temperature on transformation rate}

The effect of temperature on the transformation rate coefficient is given by:

$k_{1}=f_{T} \cdot k_{1, r e f}$

with:

$f_{\mathrm{T}} \quad=$ factor for the effect of temperature on the rate coefficient (-)

$k_{1, \text { ref }}=$ rate coefficient for transformation at reference conditions $\left(\mathrm{d}^{-1}\right)$

Both the transformation of substance in the water layer and in the sediment depends on the temperature. The factor for the effect of temperature on the rate coefficient of transformation, $f_{\mathrm{T}}$, is calculated with the Arrhenius equation:

$f_{T}=\exp \left[\frac{-\Delta H_{t}}{R}\left(\frac{1}{T}-\frac{1}{T_{r}}\right)\right]$

with:

$\Delta H_{\mathrm{t}} \quad=$ molar enthalpy of transformation (Arrhenius activation energy) $\left(\mathrm{J} \mathrm{mol}^{-1}\right)$

$R=$ universal gas constant $\left(\mathrm{J} \mathrm{mol}^{-1} \mathrm{~K}^{-1}\right)$

$T \quad=$ temperature $(\mathrm{K})$

$T_{\mathrm{r}} \quad=$ reference temperature $(\mathrm{K})$

The reference temperature, $T_{\mathrm{r}}$, is taken to be $293.15 \mathrm{~K}$. The lowest temperature that is simulated by TOXSWA is $4^{\circ} \mathrm{C}$, hence the minimum temperature used in the Arrhenius equation is $4^{\circ} \mathrm{C}$. There is no upper limit for the temperature and therefore also not for the maximum temperature used in the Arrhenius equation. 



\section{General discussion}

\subsection{Model sensitivity, verification, use and testing}

\subsubsection{Sensitivity and uncertainty analysis}

Westein et al. (1998) performed a sensitivity analysis for a watercourse with constant flow and spray drift entry only with TOXSWA 1.0. The exposure concentrations calculated by TOXSWA were most sensitive to the following parameters: half-life of the substance in the water layer, coefficient for sorption to macrophytes, Henry coefficient, flow velocity and water depth. TOXSWA 2.1 (kernel implemented the FOCUS_TOXSWA 1.1.1 software) was briefly evaluated on the uncertainties related to the calculated exposure concentrations calculated in waterbodies with transient flow. The timing of application of the pesticide versus rainfall event is the most important factor affecting the calculated exposure concentrations in FOCUS surface water scenarios (p. 216-224 in FOCUS, 2001).

\subsubsection{Verification}

The accuracy of the numerical approximations for the pesticide were tested against analytical solutions (Adriaanse, 1996). This was done for the water layer and for the sediment with a pesticide subject to sorption and to transformation. In the water layer constant flow was simulated. In the sediment downward seepage was simulated. The transport after a pulse input of the pesticide in the system was simulated. In both compartments the concentration profiles calculated by the model showed an excellent correspondence with analytical solutions.

\subsubsection{Model use and testing}

Adriaanse et al. (2013) applied TOXSWA for a ditch, modelled as a pond-type system with sloping walls and no flow. A procedure was designed that was suitable for estimating the degradation rate in water from mesocosm studies with limited datasets. The procedure was tested on a dataset for prosulfocarb in stagnant ditches. Ter Horst \& Koelmans (2016) applied TOXSWA as part of a semiglobal parameter estimation procedure for estimation of degradation rates in water and in sediment using artificial experimental datasets of water-sediment studies. A series of pesticides ranging in sorption and degradation properties were simulated. Diepens et al. (2016) applied TOXSWA for a pond with transient flow. Chlorpyrifos concentrations in sediment were simulated, and its exposure was combined with effect models. Adriaanse et al. (2017) applied TOXSWA for streams with transient flow, combined with runoff fluxes calculated by PRZM. Simulations were done with substances with varying sorption coefficients.

\subsection{Ongoing developments}

\subsubsection{Introduction}

In this section ongoing developments are discussed. At the moment we are working on the next version of the TOXSWA kernel (version 3.4). This version is not yet released, but used occasionally for research purposes only. Some of the items discussed in this Section 9.2 are already operational in TOXSWA 3.4. Other concepts are implemented but not yet fully tested and its implementation is not yet described. 
The following two concepts are already operational in TOXSWA 3.3, but not described in the main parts of this report: a new hydrology concept, i.e. the so-called 'simple ditch' model (Section 9.2.2) and the concept for atmospheric deposition (Section 9.2.3). Reason for not describing these concepts in the main parts of the report is that we constrained the report to those concepts relevant for simulations with the Dutch scenarios (TOXSWA 1.2) and with the FOCUS Surface Water scenarios.

\subsubsection{Hydrology}

Opheusden et al. (2011) derived a model for gradually varied flow from the basic principles of conservation of mass and momentum. The effect of external inflow from fields adjacent to the watercourse is considered in the model as well. The only restriction for this model is that the principle of gradual varying flow must be maintained, which implies that the external flow density must not change too rapidly along the channel. This concept is not implemented in TOXSWA. Part of the study of Opheusden et al. (2011) was to test the model derived for different situations, both for very slowly, and more rapidly flowing watercourses. As result of the tests it was shown that the water level is almost horizontal for watercourses with slow-flowing water. A simplified version of the model for gradually varied flow was developed for slow-flowing watercourses; the so-called 'simple ditch' model. This model approximates the discharge-water depth relationship by assuming that $\delta Q(x, t) / \delta x($ and thus the water depth) is constant over the entire length of the watercourse. The 'simple ditch' model was implemented in TOXSWA 3.3 in order to perform simulations with the Dutch scenario for downwards spraying of field crops developed by Tiktak et al. (2012). TOXSWA 3.3 is implemented within the GEM (Greenhouse Emission Model) software tool (Wipler et al., 2015b). For calculating the hydrology in the watercourse of the Dutch greenhouse scenarios in GEM the 'simple ditch' model in TOXSWA is used in conjunction with an imposed time-varying external upstream water flux.

\subsubsection{Atmospheric deposition}

A concept for atmospheric deposition has been implemented in TOXSWA 3.3. It is based upon a firsttier approach developed by FOCUS (2008). This approach aims at estimating deposition of plant protection products on edge-of-field surface waters due to volatilisation after application on the adjacent field, if drift mitigation is required. In the approach it is assumed that the wind blows perpendicular to the direction of the ditch which is a worst-case assumption. Furthermore, in the approach implemented in TOXSWA it is assumed that the deposition event starts at the time of application and has a constant deposition rate during the next 24 hours. The concept implemented in TOXSWA is described in Tiktak et al. (2012; section 7.3). TOXSWA 3.3 was used to perform simulations with the Dutch scenario for downwards spraying of field crops developed by Tiktak et al. (2012). In these simulations atmospheric deposition was simulated as one of pesticide entry routes in the watercourse of the scenario.

\subsubsection{Temperature}

In the TOXSWA model the dissipation processes of transformation in water and in sediment and volatilization from water to the air are a function of the ambient temperature. In the version of TOXSWA described here (version 3.3) the water temperature is approximated using monthly averages of either measured water temperature or air temperatures. However, the temperature in small water bodies is strongly influenced by weather conditions that vary at time scales down to less than one hour. Therefore, Jacobs et al. (2010) developed a 1D-bulk model for simulation of the thermal behaviour of water bodies. This model considers basic physically processes that describe the influence of weather on the energy balance of natural water bodies. This new temperature model has been implemented in TOXSWA 3.4 and a report describing its implementation, some example calculations and some specifically designed tests of the new temperature module in TOXSWA is currently prepared (Beltman et al., in prep).

\subsubsection{Volatilisation}

At present in TOXSWA the exchange flux of the pesticide between the water layer and the atmosphere $\left(J_{a}\right)$ is described by the so-called stagnant film model of Liss and Slater (1974). A drawback of this 
approach is that it does not describe the influence of weather and the hydrodynamic conditions in the water on the volatilization process. Jacobs and Adriaanse (2012) propose a new approach for calculating volatilization. The approach proposed corresponds well with the assumption of vertically well-mixed water bodies that used in the present version of TOXSWA. Jacobs and Adriaanse (2012) recommend casting the new approach in a micrometeorological framework, based upon two atmospheric resistances and on aqueous resistance against gas transport. The proposed approach will also fit smoothly in the envisaged new temperature module discussed in Section 9.2.4.

Implementation of the proposed approach of Jacobs and Adriaanse (2012) is not yet foreseen, but can be done once the new temperature model is implemented in TOXSWA (Beltman et al., in prep).

\subsubsection{Bioturbation}

Pesticides may accumulate in sediments and may pose a risk to benthic organisms. The vertical distribution of pesticide in the sediment determines to a large extent the relative importance of exposure routes via pore water and via ingestion. The vertical distribution is driven by diffusion in pore water, degradation, adsorption and bioturbation. Bioturbation is associated with considerable increase in the vertical transport due to bioactivity. Bioturbation was implemented as a particle dispersion process (Koelmans et al., 2000) in TOXSWA 3.4. The implementation is not yet fully tested and documented. However, Wipfler et al. (2016) compared chlorpyrifos exposure profiles calculated with TOXSWA 3.4 simulating i) bioturbation and ii) no bioturbation. They showed that the profiles of pore water concentrations did not deviate much; however, organic matter bound concentrations were lower in the top $2 \mathrm{~mm}$ when bioturbation was considered.

\subsubsection{Transformation}

As explained in section 8.2 TOXSWA versions up to 3.3 simulate transformation in water as a lumped first-order transformation process, assuming one transformation rate for the total mass in the water layer. Transformation in water, however, may be split in at least three separate processes; hydrolysis, photolysis and biotic transformation (Deneer et al., 2010). Simulation of these processes separately and in more detail is expected to improve the performance of TOXSWA as it accounts better for external environmental conditions related to specific pesticide properties. Deneer et al. (2010) provided suggestions for how these individual processes could be implemented in TOXSWA. Photolysis has been implemented in TOXSWA 3.4 and a description of its implementation, example calculations and some specifically designed tests are described in Beltman et al. (2015). Hydrolysis and biotic transformation are currently implemented in TOXSWA 3.4 and work on the description of its implementation, some example calculations and some specifically designed tests of these new processes in TOXSWA is currently ongoing (Ter Horst et al., in prep).

\subsection{Landscape scale modelling}

The CASCADE-TOXSWA model has been developed to assess the fate of pesticides in an interconnected system of watercourses with different hydrological characteristics (Van den Berg et al., 2011). It is based on TOXSWA, but CASCADE-TOXSWA only considers the water layer in the system of watercourses. The sediment compartment has not been implemented. The transport processes being considered are advection and dispersion. The transfer of the pesticide from one watercourse to a receiving watercourse depends on the water discharge at the end of the watercourse and the pesticide concentration in this water flow. Dispersion is not yet taken into account at junctions. Spray drift is the only entry route considered. Other processes are simulated as in TOXSWA. Focks et al. (2013) show that other watercourses discharging into the same receiving watercourse may dilute the pesticide concentration in the receiving watercourse or add to the mass entering this watercourse. Furthermore, Focks et al. (2013) show that the spatio-temporal explicit exposure patterns simulated with CASCADETOXSWA could be used directly as input for population effect modelling. 



\section{References}

Adriaanse, P.I. (1996). Fate of pesticides in field ditches: the TOXSWA simulation model. Report 90, DLO Winand Staring Centre, Wageningen, The Netherlands.

Adriaanse, P.I., Beltman, W.H.J. (2009). Transient water flow in the TOXSWA model (FOCUS versions): concepts and mathematical description. Report 101, Wettelijke Onderzoekstaken Natuur \& Milieu, Wageningen, The Netherlands.

Adriaanse, P.I., Beltman, W.H.J., Van den Berg, F. (2014). Metabolite formation in water and in sediment in the TOXSWA model. Theory and procedure for the upstream catchment of FOCUS streams. Wageningen, Alterra Wageningen UR (University and Research centre). Alterra report 2587.

Adriaanse, P.I., J.J.T.I. Boesten, S.J.H. Crum (2013). Estimating degradation rates in outdoor stagnant water by inverse modelling with TOXSWA: a case study with prosulfocarb. Pest Management Science 69 (6). :755-767.

Adriaanse, P.I., R.C. van Leerdam, J.J.T.I. Boesten (2017). The effect of the runoff size on the pesticide concentration in runoff water and in FOCUS streams simulated by PRZM and TOXSWA. Sci. Total Environ. http://dx.doi.org/10.1016/j.scitotenv.2016.12.001.

Akan, A.O. (2006). Open channel hydraulics. Elsevier, UK. 364 pp.

Ashauer, R., Brown, C.D. (2007). Comparison between FOCUS output for pesticides concentrations over time and field observations. Project code PS 2231, Department for Environment, food and Rural Affairs. http://randd.defra.gov.uk/Document.aspx?Document=PS2231_7919_FRP.doc

Beltman, W.H.J., Adriaanse, P.I., Jacobs, C.M.J., Mulder, H.M. (in prep). Temperature in water and sediment in the pesticide model TOXSWA. Implementation report. Wageningen, Wageningen Environmental Research, Report in prep.

Beltman, W.H.J. and P.I. Adriaanse (1999). Proposed standard scenarios for a surface water model in the Dutch authorization procedure of pesticides. Method to define standard scenarios determining exposure concentrations by the TOXSWA model. Report 161, DLO Winand Staring Centre, Wageningen, Netherlands.

Beltman, W.H.J., M.M.S. ter Horst, P.I. Adriaanse, A. de Jong, J.W. Deneer (2014). FOCUS_TOXSWA manual 4.4.2 : User's Guide version 4. Wageningen, WOt technical report 14, 130p.

Beltman, W.H.J., Mulder, H.M., Horst, ter M.M.S., Wipfler, E.L. (2015). Transformation by photolysis in water in the pesticide model TOXSWA : implementation report. Alterra-rapport 2649, Alterra, Wageningen.

Bolt, G.H. (ed) (1979). Soil chemistry. B. Physico-chemical models. Elsevier, Amsterdam.

Bos, M.G. (ed) (1976). Discharge measurement structures. ILRI Publication 20, International Institute for Land Reclamation and Improvement (ILRI), Wageningen, The Netherlands, $464 \mathrm{pp}$.

Chow, V.T. (1959). Open-channel hydraulics. McGraw-Hill Book Company, USA, 680 pp.

De Bruin H.A.R. and H.R.A. Wessels (1988). A model for the formation and melting of ice on surface waters. J. Appl. Meteor., 27, 164-173.

De Heer, H. (1979). Measurements and computations on the behaviour of the insecticides azinphos-methyl and dimethoate in ditches. Agric. Res. Rep. 884. Pudoc, Wageningen.

Deneer, J.W., P.I. Adriaanse, C. van Griethuysen, J.J.T.I. Boesten (2015). Estimation of degradation rates in cosm water : Guidance for inverse modelling using TOXSWA. Wageningen, Alterra Wageningen UR, Alterra-rapport 2679, $151 \mathrm{p}$.

Diepens, N.J., W.H.J. Beltman, A.A. Koelmans, P.J. Van den Brink, P.J., J.M. Baveco (2016). Dynamics and recovery of a sediment-exposed Chironomus riparius population: A modelling approach. Environmental Pollution, 213, pp.741-750.

EU (2009). Regulation 1107/2009 of the European Parliament and of the Council of 21 October 2009 concerning the placing of plant protection products on the market and repealing Council Directives 79/117/EEC and 91/414/EEC. Official Journal of the European Communities L309:1-50.

Fischer, H.B., E.J. List, R.C.Y. Koh, J. Imberger and N.H. Brooks (1979). Mixing in inland and coastal waters. Academic Press Inc, USA, 483 pp.

Focks, A., Ter Horst, M.M.S., Van den Berg, E., Baveco, H., Van den Brink, P.J. (2014). Integrating chemical fate and population-level effect models for pesticides at landscape scale: new options for risk assessment. Ecol Model 280:102-116. doi: $10.1016 /$ j.ecolmodel.2013.09.023 
FOCUS (2001). FOCUS surface water scenarios in the EU evaluation process under 91/414/EEC. Report of the FOCUS Surface Water Scenarios Workgroup (P.I. Adriaanse, R. Allen, E. Capri, V. Gouy, J. Hollis, N. Jarvis, M. Klein, J. Linders, P. Lolos, W-M Maier, S. Maund, M.H. Russell, J-L Teixeira, S. Vizantinopoulos and D. Yon), EC. Document Reference SANCO/4802/2001-rev2.

FOCUS (2008). Pesticides in Air: Considerations for Exposure Assessment. Report of the FOCUS Working Group on Pesticides in Air, EC Document Reference SANCO/10553/2006 Rev 2.

Jacobs, C.M.J., Adriaanse, P.I. (2012). Pesticide volatilization from small surface waters: rationale of a new parameterization for TOXSWA. Wageningen, Alterra, Alterra-report 2316.

Jacobs, C.M.J., Deneer, J.W., Adriaanse, P.I. (2010). Modelling water temperature in TOXSWA. Wageningen, Alterra, Alterra-report 2099.

Jury, W.A., K. Roth (1990). Transfer functions and solute movements through soil. Theory and applications. Birkhäuser Verlag, Basel.

Koelmans, A.A.; Hubert, E.; Koopman, H.W.; Portielje, R.; Crum, S.J.H. (2000). Modeling the vertical distribution of carbendazim in sediments. Environmental Toxicology and Chemistry 19 (4 I). - p. 793 - 800 DOI: 10.1002/etc. 5620190403

Leistra, M., A.M.A. van der Linden, J.J.T.I. Boesten, A. Tiktak, F. van den Berg (2001). PEARL model for pesticides beahviour and emissins in plant-soil systems. Descriptions of the processes in FOCUS PEARL v1.1.1. AlterraRapport 013, RIVM report 711401009. Alterra Wageningen UR, Wageningen / National Institute of Public Health and the Environment (RIVM), Bilthoven.

Liss, P.S. \& Slater, P.G. (1974). Flux of gasses across the air-sea interface. Nature 247 : 181-184.

Opheusden, J.H.J., Molenaar, J., Beltman, W.H.J., Adriaanse, P.I. (2011). Non-stationary flow solution for water levels in open channels for TOXSWA. Alterra report 2166, Alterra, Wageningen, the Netherlands.

Querner, E.P. (1993). Aquatic weed control within an integrated water management framework. Report 67, DLO Winand Staring Centre for Integrated Land, Soil and Water Research (PhD thesis), Wageningen, The Netherlands, 203 pp.

Smit, R.A.M.F.R., F. van den Berg, M. Leistra (1997). Estimation method for the volatilization of pesticides of fallow soil. Environmental Planning Bureau Series 2, DLO Winand Staring Centre, Wageningen, the Netherlands.

Ter Horst, M. M.S., A. A. Koelmans (2016). Analyzing the limitations and the applicability domain of watersediment transformation tests like OECD 308. ES\&T 50, 19: 10335-10342.

Ter Horst, M.M.S., Beltman, W.H.J.., Adriaanse, P.I., Mulder, H.M. (in prep). Transformation by hydrolysis and biotic transformation in water in the TOXSWA model. Implementation report. Wageningen, Wageningen Environmental Research, Report in prep.

Thomann, R.V., J. A. Mueller (1987). Principles of surface water quality modeling and control. Harper \& Row, Publishers.

Tiktak, A. , Adriaanse, P.I. , Boesten, J.J.T.I. ,Van Griethuysen, C., Ter Horst, M.M.S. , Linders, J.B.H.J. , Van der Linden, A.M.A., Van de Zande, J.C. (2012). Scenarios for exposure of aquatic organisms to plant protection products in the Netherlands : part 1: Field crops and downward spraying. Bilthoven : National Institute for Public Health and the Environment, (RIVM report ) - 129 p.

Van den Berg, F., ter Horst, M.M.S, Beltman, W.H.J. , Adriaanse, P.I. , Boesten, J.J.T.I. , Groenwold, J.G \& Kruijne, R. (2011). Assessment of pesticide exposure concentrations in a small catchment using the CascadeToxswa model. The XIII Pesticide Chemistry Symposium, Piacenza, Italy, 2011-8-30/2011-9-1

Vennard, J.K. and R.L. Street (1976). Elementary Fluid Mechanics (SI version, 5th ed). John Wiley\&Sons Inc, USA, $740 \mathrm{pp}$.

Westein, E., M.J.W. Jansen, P.I. Adriaanse \& W.H.J. Beltman (1998). Sensitivity analysis of the TOXSWA model simulating fate of pesticides in surface waters. Wageningen, SC-DLO, Report 154, $119 \mathrm{pp}$.

Wipfler, E.L., Bergstedt, H., Baveco, J.M., Beltman, W.H.J., Koelmans, A.A. (2016). Modelling the effect of bioturbation on pesticide exposure of benthic Chironomus riparius populations. SETAC annual meeting 2016, Nantes, 2016-05-22/2016-05-26.

Wipfler, E.L., A.M.A. van der Linden, E.A. van Os, G.J. Wingelaar, A.A. Cornelese and H. Bergstedt (2015a). Scenarios for exposure of aquatic organisms to plant protection products in the Netherlands. Impact analysis of new soilless cultivation scenarios. Alterra Report 2604, Wageningen, the Netherlands.

Wipfler, E.L., C. Vink, M.M.S. ter Horst \& A. de Jong (2015b). Manual GEM 1.1.1, Greenhouse Emission Model, exposure assessment tool for Plant Protection Products used in greenhouse crop cultivation. Alterra report 2614, Wageningen. 


\section{Justification}

This report describes the mathematical concepts of TOXSWA version 3.3 i.e. the TOXSWA kernel that is incorporated in the FOCUS_TOXSWA 4.4.3 software tool. This report is constrained to describing those concepts in TOXSWA 3.3 that are relevant for simulations with the Dutch (excluding the greenhouse scenarios) and FOCUS surface water scenarios. Mathematical concepts are described independent of specific scenario properties.

The TOXSWA model is currently used for different purposes, e.g. calculation of exposure concentrations in the water layer and in the sediment of surface waters at the EU (FOCUS-TOXSWA) and at the national level (TOXSWA 1.2) of the registration procedure of pesticides and the calculation of exposure concentrations in the water layer and in the sediment of surface waters as result of pesticide emissions from greenhouses (GEM).

The report was written by several members of the TOXSWA development team of Wageningen Environmental Research (Alterra). The project was supervised by Jennie van der Kolk (contact of WOT N\&M, theme Agri-environment) and Anja van Gemerden (Ministry of Economic Affairs). 



\section{Annex 1 List of symbols and units}

\begin{tabular}{|c|c|c|}
\hline Symbol & Description $^{8}$ & Units \\
\hline$\beta$ & $\arctan \left(1 / s_{1}\right)$ & $\mathrm{rad}$ \\
\hline$\delta$ & Dirac delta function & $d^{-1}$ \\
\hline$\varepsilon$ & volume fraction of pore water & - \\
\hline$\Phi$ & $\begin{array}{l}\text { lineic volume flux of water, that is lateral inflow originating from drainage or runoff including } \\
\text { drainage subsurface flow from the adjacent field }\end{array}$ & $m^{3} m^{-1} d^{-1}$ \\
\hline$\kappa_{\mathrm{M}}$ & Manning's coefficient of channel roughness & $m^{1 / 3} d^{-1}$ \\
\hline$\kappa_{\mathrm{M}, 1 \mathrm{~m}}$ & $\begin{array}{l}\text { coefficient defining Manning's coefficient for channel roughness in a channel with a } 1 \mathrm{~m} \text { water } \\
\text { depth }\end{array}$ & $d^{-1}$ \\
\hline$\lambda$ & relative diffusion coefficient (or tortuosity) & - \\
\hline$\xi(\mathrm{t})$ & the release time function & 1 \\
\hline$\rho_{\mathrm{b}}$ & bulk density of dry sediment, i.e. volumic mass of dry sediment material & $\mathrm{kg} \mathrm{m}^{-3}$ \\
\hline$\omega$ & average flow velocity of pore water & $\mathrm{m} \mathrm{d}^{-1}$ \\
\hline$\chi_{p, 1}$ & molar fraction of parent transformed to product 1 & - \\
\hline$A$ & wetted cross sectional area of flow & $\mathrm{m}^{2}$ \\
\hline$A_{\text {contr, pond }}$ & area next to the pond contributing water to the pond & $\mathrm{m}^{2}$ \\
\hline$A_{\mathrm{x}}$ & wetted cross sectional area of flow at location $x$ & $\mathrm{~m}^{2}$ \\
\hline$A_{\text {up }}$ & size of the upstream catchment area & ha \\
\hline$b$ & bottom width of the waterbody & $\mathrm{m}$ \\
\hline$b_{\text {crest }}$ & width of weir crest & $\mathrm{m}$ \\
\hline$C_{\text {weir }}$ & discharge coefficient, depending on weir characteristics & $m^{1 / 2} d^{-1}$ \\
\hline$c_{a}$ & mass concentration of substance in the air & $\mathrm{kg} \mathrm{m}^{-3}$ \\
\hline$c_{\mathrm{ss}, \mathrm{r}}$ & reference concentration in the liquid phase for sorption to suspended solids $\left[c_{e, s s}\right]$ & $\mathrm{kg} \mathrm{m}^{-3}$ \\
\hline$c_{\mathrm{s}, \mathrm{r}}$ & reference concentration in the liquid phase for sorption to sediment $\left[c_{\mathrm{e}, \mathrm{wb}}\right]$ & $\mathrm{kg} \mathrm{m}^{-3}$ \\
\hline$c_{F}$ & coefficient & - \\
\hline$c_{\mathrm{I}}$ & equilibrium mass concentration of substance at the water-gas interface in the water phase & $\mathrm{kg} \mathrm{m}^{-3}$ \\
\hline$c_{1, s}$ & mass concentration of substance in liquid phase in the sediment $\left[c_{1 b}\right]$ & $\mathrm{kg} \mathrm{m}^{-3}$ \\
\hline$c_{\mathrm{s}}{ }^{*}$ & mass concentration in the sediment $\left[c^{*}{ }_{b}\right]$ & $\mathrm{kg} \mathrm{m}^{-3}$ \\
\hline$c_{\text {spg }}$ & mass concentration in seepage water & $\mathrm{kg} \mathrm{m}^{-3}$ \\
\hline$c_{\text {slb }}$ & solubility of substance in water & $\mathrm{kg} \mathrm{m}^{-3}$ \\
\hline$c_{S I b, r}$ & solubility at reference temperature & $\mathrm{kg} \mathrm{m}^{-3}$ \\
\hline$c_{u}{ }^{*}$ & $\begin{array}{l}\text { mass concentration in water discharging into the waterbody at the upstream end of the } \\
\text { waterbody }\end{array}$ & $\mathrm{kg} \mathrm{m}^{-3}$ \\
\hline$c_{w}^{*}$ & $\begin{array}{l}\text { mass concentration of substance in water layer, excluding substance sorbed to suspended } \\
\text { solids and to macrophytes }\end{array}$ & $\mathrm{kg} \mathrm{m}^{-3}$ \\
\hline$c_{w}$ & $\begin{array}{l}\text { mass concentration of substance in the water phase (excluding substance sorbed to } \\
\text { suspended solis and to macrophytes) }[c]\end{array}$ & $\mathrm{kg} \mathrm{m}^{-3}$ \\
\hline$C_{W, F}$ & concentration in water from lateral discharge, by drainage or runoff & $\mathrm{kg} \mathrm{m}^{-3}$ \\
\hline$D_{1, \mathrm{~s}}$ & diffusion coefficient in pore water $\left[D_{\mathrm{lb}}\right]$ & $m^{2} d^{-1}$ \\
\hline$D_{\mathrm{w}}$ & diffusion coefficient in water & $m^{2} d^{-1}$ \\
\hline E & areic volume flux from evaporation; the flux is negative in an upward direction & $\mathrm{m}^{3} \mathrm{~m}^{-2} \mathrm{~d}^{-1}$ \\
\hline$E_{1, \mathrm{~s}}$ & dispersion coefficient in pore water $\left[E_{\mathrm{lb}}\right]$ & $m^{2} d^{-1}$ \\
\hline$E_{\text {phys }}$ & longitudinal dispersion coefficient (in the direction of flow) & $m^{2} d^{-1}$ \\
\hline
\end{tabular}

${ }^{8}$ When the symbol differs from the symbol given by Adriaanse (1996), the symbol used by Adriaanse is added to the description between square brackets. 


\begin{tabular}{|c|c|c|}
\hline Symbol & Description $^{8}$ & Units \\
\hline$f_{\mathrm{d}}$ & $\begin{array}{l}\text { fraction of downward aeric volume flux of water at } 1 \mathrm{~m} \text { soil depth that is drained into the } \\
\text { stream }\end{array}$ & - \\
\hline$f_{\mathrm{T}}$ & factor for the effect of temperature on the rate coefficient & - \\
\hline G & $\begin{array}{l}\text { slope of the energy line, for uniform flow equal to the hydraulic gradient (difference in water } \\
\text { surface level at two locations divided by their distance), which is for uniform flow also equal } \\
\text { to the bottom slope }\end{array}$ & - \\
\hline$H$ & Heaviside function (p.26 Jury and Roth, 1990) & 1 \\
\hline$\Delta H_{\mathrm{d}}$ & molar enthalpy of dissolution in water & $\mathrm{J} \mathrm{mol}^{-1}$ \\
\hline$\Delta H_{\mathrm{t}}$ & molar enthalpy of transformation (Arrhenius coefficient) & $\mathrm{J} \mathrm{mol}^{-1}$ \\
\hline$\Delta H_{\mathrm{v}}$ & molar enthalpy of vaporization & $\mathrm{J} \mathrm{mol}^{-1}$ \\
\hline$h$ & water depth of the waterbody & $\mathrm{m}$ \\
\hline$h_{\text {crest }}$ & upstream water level over the weir crest, also called head & $\mathrm{m}$ \\
\hline$h_{\text {uni }}$ & uniform flow depth, i.e. water depth at uniform flow & $\mathrm{m}$ \\
\hline$h_{\mathrm{w}}$ & depth defining perimeter for exchange between water and sediment & $\mathrm{m}$ \\
\hline$h_{\text {weir }}$ & water depth immediately in front of weir & $\mathrm{m}$ \\
\hline$J_{\mathrm{a}}$ & $\begin{array}{l}\text { areic mass flux of substance across the water-air interface }\left(\mathrm{kg} \mathrm{m}^{-2} \mathrm{~d}^{-1}\right) \text { [the flux is negative in } \\
\text { upward direction }]\left[J_{\mathrm{wa}}\right]\end{array}$ & $\mathrm{kg} \mathrm{m}^{-2} \mathrm{~d}^{-1}$ \\
\hline$J_{\text {er }}$ & mass flux of substance associated with eroded soil & $\mathrm{kg} \mathrm{m}^{-2} \mathrm{~d}^{-1}$ \\
\hline$J_{1,5}$ & areic mass flux by advection, dispersion and diffusion in the liquid phase of the sediment $\left[J_{\mathrm{lb}}\right]$ & $\mathrm{kg} \mathrm{m}^{-2} \mathrm{~d}^{-1}$ \\
\hline$J_{\mathrm{s}}$ & areic mass flux of substance across the water-sediment interface []$\left._{\mathrm{wb}}\right]$ & $\mathrm{kg} \mathrm{m}^{-2} \mathrm{~d}^{-1}$ \\
\hline$J_{w}$ & areic mass flux of substance in water layer by advection and dispersion & $\mathrm{kg} \mathrm{m}^{-2} \mathrm{~d}^{-1}$ \\
\hline$K_{\mathrm{F}, \mathrm{s}}$ & Freundlich coefficient for sorption to sediment $\left[K_{F, w b}\right]$ & $\mathrm{m}^{3} \mathrm{~kg}^{-1}$ \\
\hline$K_{\mathrm{F}, \mathrm{ss}}$ & Freundlich coefficient for sorption to suspended solids & $\mathrm{m}^{3} \mathrm{~kg}^{-1}$ \\
\hline$K_{\mathrm{H}}$ & Henry coefficient & - \\
\hline$K_{\mathrm{mp}}$ & $\begin{array}{l}\text { distribution coefficient for substance between macrophytes and water, i.e. the slope of the } \\
\text { linear sorption isotherm on the mass of dry macrophytes }\end{array}$ & $\mathrm{m}^{3} \mathrm{~kg}^{-1}$ \\
\hline$K_{\mathrm{om}, \mathrm{s}}$ & coefficient of equilibrium sorption on organic matter in sediment $\left[K_{\mathrm{om}, w b}\right]$ & $\mathrm{m}^{3} \mathrm{~kg}^{-1}$ \\
\hline$K_{\mathrm{om}, \mathrm{ss}}$ & coefficient of equilibrium sorption on organic matter in suspended solids & $\mathrm{m}^{3} \mathrm{~kg}^{-1}$ \\
\hline$k_{g}$ & exchange coefficient of substance in the gas phase & $\mathrm{m} \mathrm{d}^{-1}$ \\
\hline$k_{1}$ & exchange coefficient of substance in the liquid phase & $\mathrm{m} \mathrm{d}^{-1}$ \\
\hline$k_{\mathrm{p}}$ & rate coefficient for transformation of the parent substance in water & $d^{-1}$ \\
\hline$k_{\mathrm{s}}$ & rate coefficient for transformation of parent substance in sediment & $d^{-1}$ \\
\hline$k_{\mathrm{t}, \mathrm{l}}$ & overall transfer coefficient of substance in the liquid phase & $\mathrm{m} \mathrm{d}^{-1}$ \\
\hline$k_{1, \text { ref }}$ & rate coefficient for transformation at reference conditions & $d^{-1}$ \\
\hline$L$ & length of the pond & $\mathrm{m}$ \\
\hline$L_{\text {dis }}$ & dispersion length & $\mathrm{m}$ \\
\hline$M_{\mathrm{m}}$ & molar mass of substance $m$ & $\mathrm{~kg} \mathrm{~mol}^{-1}$ \\
\hline$m$ & mass of substance $[M]$ & $\mathrm{kg}$ \\
\hline$m_{\text {drift }}$ & spray drift mass deposited at the water layer & $\mathrm{kg} \mathrm{m}^{-2}$ \\
\hline$m_{\llcorner}$ & lineic mass of substance $\left[M_{\mathrm{L}}\right]$ & $\mathrm{kg} \mathrm{m}^{-1}$ \\
\hline$m_{L T}$ & lineic mass of substance $\left[M_{\mathrm{LT}}\right]$ & $\mathrm{kg} \mathrm{m}^{-1} \mathrm{~d}^{-1}$ \\
\hline$m_{\mathrm{T}}$ & mass of substance $\left[M_{\mathrm{T}}\right]$ & $\mathrm{kg} \mathrm{d}^{-1}$ \\
\hline$m_{\mathrm{mp}}$ & dry weight of macrophytes per area of sediment $[D W]$ & $\mathrm{kg} \mathrm{m}^{-2}$ \\
\hline$m_{\mathrm{om}, \mathrm{s}}$ & mass fraction of organic matter in sediment $\left[m_{\mathrm{om}, \mathrm{wb}}\right]$ & $\mathrm{kg}^{-1} \mathrm{~kg}^{-1}$ \\
\hline$m_{\mathrm{om}, \mathrm{ss}}$ & mass fraction of organic matter in suspended solids & $\mathrm{kg}^{-1} \mathrm{~kg}^{-1}$ \\
\hline$m_{\mathrm{ss}}$ & mass concentration of suspended solids in the water layer [ss] & $\mathrm{kg} \mathrm{m}^{-3}$ \\
\hline$N_{\mathrm{s}}$ & Freundlich exponent for sorption to sediment $\left[n_{\mathrm{wb}}\right]$ & - \\
\hline$N_{\mathrm{ss}}$ & Freundlich exponent for sorption to suspended solids $\left[n_{s s}\right]$ & - \\
\hline$P$ & length of perimeter & $\mathrm{m}$ \\
\hline$P_{r}$ & $\begin{array}{l}\text { areic volume flux from precipitation, i.e. volume of precipitation divided by an appropriate } \\
\text { waterbody surface area and by time; the flux is positive in a downward direction }\end{array}$ & $m^{3} m^{-2} d^{-1}$ \\
\hline$P_{\mathrm{D}}$ & length of perimeter at lower boundary of sediment at depth $z=D$ & $\mathrm{~m}$ \\
\hline$P_{\text {sat }}$ & saturated vapour pressure of substance $[P]$ & $\mathrm{m}$ \\
\hline$P_{\text {sat }, r}$ & saturated vapour pressure at reference temperature & $\mathrm{Pa}$ \\
\hline
\end{tabular}




\begin{tabular}{|c|c|c|}
\hline Symbol & Description $^{8}$ & Units \\
\hline$P_{\text {wet }}$ & length of wetted perimeter of the waterbody & $\mathrm{Pa}$ \\
\hline$p_{\text {weir }}$ & height of weir crest above waterbody bottom & $\mathrm{m}$ \\
\hline$P_{\mathrm{z}}$ & length of perimeter at depth $z$ from the water-sediment interface & $\mathrm{m}$ \\
\hline$P_{1 / 2 z \text { mix }}$ & length of wetted perimeter at $z=1 / 2 z_{\text {mix }}$ in sediment & $\mathrm{m}$ \\
\hline$P_{0, \mathrm{x}}$ & $\begin{array}{l}\text { length of wetted perimeter at the water-sediment interface ( } z=0 \text { from the perspective of } \\
\text { the sediment) at location } x\end{array}$ & $\mathrm{~m}$ \\
\hline$P_{0}$ & $\begin{array}{l}\text { length of wetted perimeter at depth } z=0 \text { (from the perspective of the sediment), via which } \\
\text { exchange between water and sediment occurs }\end{array}$ & $\mathrm{m}$ \\
\hline$Q$ & discharge, i.e. volume flux of water passing through a vertical cross-section of the waterbody & $m^{3} d^{-1}$ \\
\hline$Q_{\text {base }}$ & discharge or volume flux of the base flow delivered by the upstream catchment & $m^{3} d^{-1}$ \\
\hline Qout & discharge of water at the downstream end of the waterbody & $m^{3} d^{-1}$ \\
\hline$Q_{u}$ & total discharge or volume flux of water entering the waterbody at the upstream boundary & $m^{3} d^{-1}$ \\
\hline$Q_{\text {weir }}$ & discharge at the location of the weir & $m^{3} d^{-1}$ \\
\hline$Q_{x}$ & $\begin{array}{l}\text { discharge, i.e. volume flux of water passing through a vertical cross-section of the waterbody } \\
\text { at location } x\end{array}$ & $m^{3} d^{-1}$ \\
\hline$q_{F}$ & areic volume flux of excess water from the adjacent field & $m^{3} m^{-2} d^{-1}$ \\
\hline$q_{F, \text { down }}$ & areic volume flux of excess water at $1 \mathrm{~m}$ soil depth originating from the adjacent field & $m^{3} m^{-2} d^{-1}$ \\
\hline$q_{F, r}$ & areic volume flux of surface runoff excess water from the adjacent field & $m^{3} m^{-2} d^{-1}$ \\
\hline$q_{F, s}$ & $\begin{array}{l}\text { areic volume flux from seepage flow from the adjacent field, expressed per surface area } \\
\text { adjacent field }\end{array}$ & $m^{3} m^{-2} d^{-1}$ \\
\hline$R$ & universal gas constant & $\mathrm{J} \mathrm{mol}^{-1} \mathrm{~K}^{-1}$ \\
\hline$R_{\mathrm{f}, \mathrm{p}}$ & rate of formation of parent substance in the water layer & $\mathrm{kg} \mathrm{m}^{-3} \mathrm{~d}^{-1}$ \\
\hline$R_{\mathrm{t}, \mathrm{p}, 1}$ & rate of formation of product 1 from the parent compound & $\mathrm{kg} \mathrm{m}^{-3} \mathrm{~d}^{-1}$ \\
\hline$R_{\mathrm{t}, \mathrm{p}}$ & $\begin{array}{l}\text { rate of transformation of substance in the water layer (i.e. in water phase, sorbed to } \\
\text { suspended solids and sorbed to macrophytes) }\end{array}$ & $\mathrm{kg} \mathrm{m}^{-3} \mathrm{~d}^{-1}$ \\
\hline$R_{\mathrm{s} / \mathrm{f}, \mathrm{p}}$ & rate of formation of parent substance in the sediment & $\mathrm{kg} \mathrm{m}^{-3} \mathrm{~d}^{-1}$ \\
\hline$R_{s, t, \mathrm{p}}$ & rate of transformation of parent substance in the sediment & $\mathrm{kg} \mathrm{m}^{-3} \mathrm{~d}^{-1}$ \\
\hline$R_{t, 1}$ & rate of transformation of the product 1 & $\mathrm{~kg} \mathrm{~m}^{-3} \mathrm{~d}^{-1}$ \\
\hline$R_{\text {wet }}$ & hydraulic radius of the wetted cross-section & $\mathrm{m}$ \\
\hline$r$ & number of point type inputs & - \\
\hline$S$ & areic volume flux from seepage; the flux is positive in a downward direction & $m^{3} m^{-2} d^{-1}$ \\
\hline$S_{c, \mathrm{~d}}$ & distributed source with continuous input $\left[b_{d}\right]$ & $\mathrm{kg} \mathrm{m}^{-3} \mathrm{~d}^{-1}$ \\
\hline$S_{c, p}$ & point type source with continuous input $\left[b_{p}\right]$ & $\mathrm{kg} \mathrm{m}^{-3} \mathrm{~d}^{-1}$ \\
\hline$S_{p, d}$ & distributed pulse input $\left[p_{\mathrm{d}}\right]$ & $\mathrm{kg} \mathrm{m}^{-3} \mathrm{~d}^{-1}$ \\
\hline$S_{p, p}$ & point type pulse input $\left[p_{p}\right]$ & $\mathrm{kg} \mathrm{m}^{-3} \mathrm{~d}^{-1}$ \\
\hline$s_{0}$ & number of pulse input at location $x_{0}$ & - \\
\hline$s_{00}$ & number of pulse input at location $x_{00}$ & - \\
\hline$s_{1}$ & side slope (horizontal/vertical) & - \\
\hline$T$ & temperature & K \\
\hline$T_{\mathrm{a}, \mathrm{m}}$ & monthly average of the air temperature at $2 \mathrm{~m}$ above the ground & K \\
\hline$T_{m}$ & $\begin{array}{l}\text { temperature at which the saturated vapour pressure, the solubility and the exchange } \\
\text { coefficients are defined }\end{array}$ & K \\
\hline$T_{\mathrm{r}}$ & reference temperature & K \\
\hline$T_{\mathrm{wb}}$ & temperature of the waterbody & K \\
\hline$t$ & time & d \\
\hline$t_{\mathrm{re}}$ & time at which the continuous release at location $x_{r e}$ ends & d \\
\hline$t_{\mathrm{rs}}$ & time at which the continuous release at location $x_{\text {rs }}$ starts & d \\
\hline$t_{\mathrm{s}}$ & time of pulse input & d \\
\hline$t_{s 0}$ & time of input & $d$ \\
\hline$u$ & flow velocity of the water & $m d^{-1}$ \\
\hline $\bar{u}$ & average cross-sectional flow velocity & $\mathrm{m} \mathrm{d}^{-1}$ \\
\hline$u^{*}$ & shear velocity & $\mathrm{m} \mathrm{d}^{-1}$ \\
\hline$w$ & width of water surface & $\mathrm{m}$ \\
\hline$W_{\mathrm{x}}$ & width of water surface at location $x$ & $\mathrm{~m}$ \\
\hline
\end{tabular}




\begin{tabular}{|c|c|c|}
\hline$w_{\mathrm{er}}$ & width of the adjacent field of which soil is eroded & $\mathrm{m}$ \\
\hline$w_{\mathrm{F}}$ & $\begin{array}{l}\text { width of the adjacent field (perpendicular to the waterbody) discharging drainage or runoff } \\
\text { water into the waterbody }[\ell]\end{array}$ & $\mathrm{m}$ \\
\hline$X_{\mathrm{mp}}$ & content of substance sorbed to macrophytes & $\mathrm{kg} \mathrm{kg}^{-1}$ \\
\hline$X_{\mathrm{s}}$ & mass sorbed to sediment $\left[X_{\mathrm{b}}\right]$ & $\mathrm{kg} \mathrm{kg}^{-1}$ \\
\hline$X_{\mathrm{ss}}$ & mass content sorbed to suspended solids & $\mathrm{kg} \mathrm{kg}^{-1}$ \\
\hline$x$ & distance in the direction of flow & $\mathrm{m}$ \\
\hline$x_{\mathrm{rs}}$ & location at which the continuous release starts & $\mathrm{m}$ \\
\hline$x_{\mathrm{re}}$ & location at which the continuous release ends & $\mathrm{m}$ \\
\hline$x_{0}$ & location of input & $\mathrm{m}$ \\
\hline$x_{00}$ & number of location $x_{00}$ & - \\
\hline$z$ & depth in the sediment from the water-sediment interface to area concerned & $\mathrm{m}$ \\
\hline$z_{\text {mix }}$ & thickness of top layer of sediment, into which pesticide sorbed to eroded soil is distributed & $\mathrm{m}$ \\
\hline
\end{tabular}




\section{Annex 2 Lateral entries in the waterbody}

\section{A2.1 Introduction}

Lateral entries of pesticides into the waterbody are inputs that are included as options in the conservation equation. This Annex provides the mathematical concepts for all four types of lateral entries.

The mass conservation equation for the pesticide in the water layer is extended with four types of entries of pesticide is:

$\frac{\partial\left(c_{w}^{*} A\right)}{\partial t}=-\frac{\partial\left(A \cdot J_{w}\right)}{\partial x}-R_{t, p} A+J_{a} W-J_{s} P_{0}+S_{p, p} A+S_{p, d} A+S_{c, p} A+S_{c, d} A$

with:

$S_{p, p}(t, x)=$ point type pulse input $\left(\mathrm{kg} \mathrm{m}^{-3} \mathrm{~d}^{-1}\right)$

$S_{\mathrm{p}, \mathrm{d}}(t, x)=$ distributed pulse input $\left(\mathrm{kg} \mathrm{m}^{-3} \mathrm{~d}^{-1}\right)$

$S_{c, p}(t, x)=$ point type source with continuous input $\left(\mathrm{kg} \mathrm{m}^{-3} \mathrm{~d}^{-1}\right)$

$S_{c, \mathrm{~d}}(t, x)=$ distributed source with continuous input $\left(\mathrm{kg} \mathrm{m}^{-3} \mathrm{~d}^{-1}\right)$

Pulse type inputs (point type and distributed) are released into the water layer in an infinitesimally small period of time, so a certain mass of substance is released into the water layer (e.g. point type: spillage; distributed: spray drift event). Sources with continuous input (point type and distributed) are released into the waterbody as flux, i.e. mass released during a time interval as a rate (e.g. point: single discharging drain; distributed: series of discharging drains in an agricultural field).

Each of the four types of lateral input is described in sections A2.2 - A2.5. However, not all four types are operational in TOXSWA. The point type pulse input and the point type source with continuous input are not implemented. The distributed pulse input and the distributed source with continuous input are implemented in TOXSWA. For those lateral input entries that are operational in TOXSWA the specific implementation for the corresponding entry route(s) is given in Chapter 5.

The mass conservation equation for the pesticide in the sediment is also extended with four types of entries of pesticide is:

$P \frac{\partial c_{s}^{*}}{\partial t}=\frac{\partial\left(P \cdot J_{l, s}\right)}{\partial z}-R_{s, t, p} P+S_{p, p} P+S_{p, d} P+S_{c, p} P+S_{c, d} P$

with:

$S_{\mathrm{p}, \mathrm{p}}(t, z)=$ point type pulse input $\left(\mathrm{kg} \mathrm{m}^{-3} \mathrm{~d}^{-1}\right)$

$S_{p, d}(t, z)=$ distributed pulse input $\left(\mathrm{kg} \mathrm{m}^{-3} \mathrm{~d}^{-1}\right)$

$S_{c, p}(t, z)=$ point type source with continuous input $\left(\mathrm{kg} \mathrm{m}^{-3} \mathrm{~d}^{-1}\right)$

$S_{c, \mathrm{~d}}(t, z)=$ distributed source with continuous input $\left(\mathrm{kg} \mathrm{m}^{-3} \mathrm{~d}^{-1}\right)$

Considering the sediment the distributed source with continuous input has been implemented in TOXSWA. The specific implementation for the corresponding entry route (erosion) is given in Chapter 5. 


\section{A2.2 Point-type pulse input}

Note that this type of input is currently not implemented in TOXSWA. Example of point-type pulse inputs are e.g. spillage of the substance or rinsing application equipment. The mass of substance, released in an infinitesimally short time, $m(\mathrm{~kg})$ is assumed to be in an infinitesimally thin, vertical slice of the waterbody. Such a pulse input, occurring repeatedly, can be described by:

$S_{p, p}(t, x)=\sum_{s_{0}=1}^{m_{0}} \frac{m \delta\left(x-x_{0}\right) \delta\left(t-t_{s_{0}}\right)}{A}$

with:

$m \quad=$ mass of substance $(\mathrm{kg})$

so $\quad=$ number of pulse input at location $x_{0}$

$m_{0} \quad=$ total number of inputs $(-)$

$x_{0} \quad=$ location of input $(\mathrm{m})$

$t_{s 0} \quad=$ time of input $(\mathrm{d})$

In Eq. $\left((75) \delta\left(x-x_{0}\right)\right.$ is the Dirac delta function $\left(\mathrm{m}^{-1}\right)$ defined by (see Figure 18$)$ :

$\delta\left(x-x_{0}\right)=0 \quad$ for $\quad x \neq x_{0} \quad$ and

$\int_{-\infty}^{\infty} \delta\left(x-x_{0}\right) d x=1$

In Eq. (75) $\delta\left(t-t_{\mathrm{s} 0}\right)$ is the Dirac delta function $\left(\mathrm{d}^{-1}\right)$ defined by (see Figure 19):

$\delta\left(t-t_{s 0}\right)=0$ for $t \neq t_{s 0} \quad$ and

$\int_{-\infty}^{\infty} \delta\left(t-t_{s_{0}}\right) d t=1$

If such a pulse input occurs at a second location, the term $S_{p, p}(t, x)$ becomes as follows (for every subsequent location another term is added):

$S_{p, p}(t, x)=\sum_{s_{0}=1}^{m_{0}} \frac{m \delta\left(x-x_{0}\right) \delta\left(t-t_{s_{0}}\right)}{A}+\sum_{S_{00}=1}^{m_{00}} \frac{m \delta\left(x-x_{00}\right) \delta\left(t-t_{s_{00}}\right)}{A}$

with:

$x_{00}=$ location $x_{00}(\mathrm{~m})$

$s_{00}=$ number of pulse input at location $x_{00}$

$m_{00}=$ total number of inputs at location $x_{00}$ 


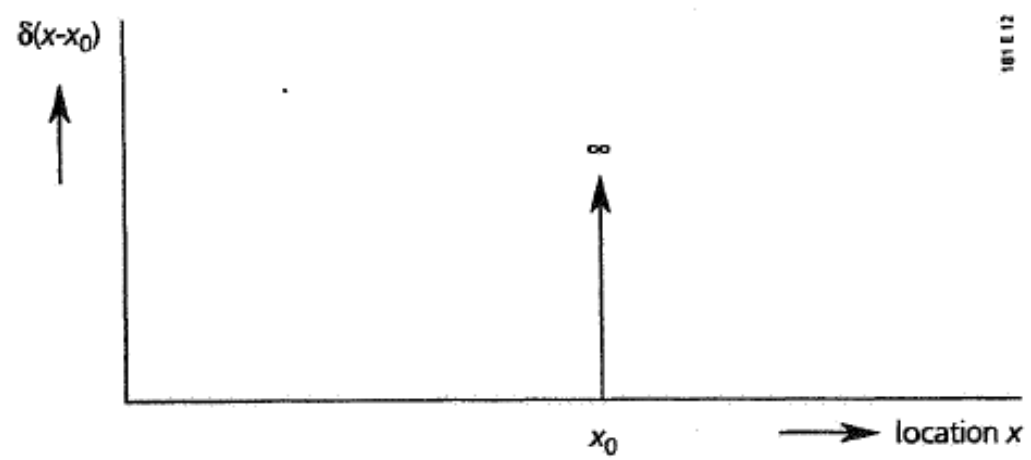

Figure 18 Dirac delta function for point type input

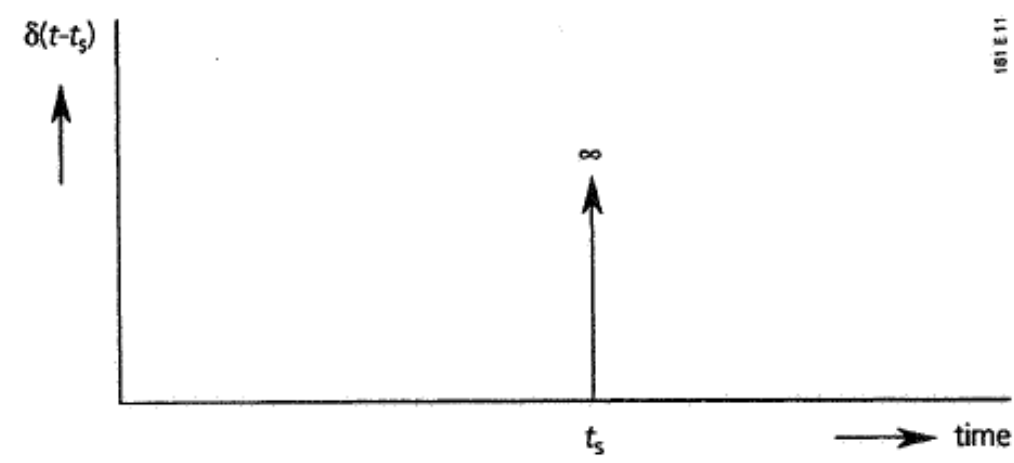

Figure 19 Dirac delta function for pulse input

\section{A2.3 Point-type distributed input}

Spray drift is modelled as a distributed pulse input. It is assumed that the supplied lineic mass of substance $m_{\mathrm{L}}\left(\mathrm{kg} \mathrm{m}^{-1}\right)$ is instantaneously and ideally mixed in the water layer at the time of release. Such a pulse input, occurring repeatedly, can be described by:

$S_{p, d}(t, x)=\sum_{s_{0}=1}^{m_{0}} \frac{m_{L} \delta\left(t-t_{s_{0}}\right)}{A}$

with

$m_{\mathrm{L}} \quad=$ lineic mass of substance $\left(\mathrm{kg} \mathrm{m}^{-1}\right)$

For simplicity reasons we consider a single event, hence Eq. (79) becomes

$S_{p, d}(t, x)=\frac{m_{L}}{A} \delta\left(t-t_{s}\right)$

with

$\delta \quad=\quad$ Dirac delta function $\left(\mathrm{d}^{-1}\right)$

$t_{\mathrm{s}} \quad=\quad$ time of pulse input $(\mathrm{d})$

The Dirac delta function (in Eq. (80) can be defined as the derivative of the Heaviside function (p.26 Jury and Roth, 1990). The Heaviside function (dimension 1) is defined as

$$
\begin{gathered}
H\left(t-t_{s 0}\right)=0 \text { if } t<t_{s} \\
H\left(t-t_{s 0}\right)=1 \text { if } t>t_{s}
\end{gathered}
$$


and its derivative

$\delta\left(t-t_{s}\right)=\frac{\partial H\left(t-t_{s}\right)}{\partial t}$

Hence, replacing the Dirac delta function in Eq. (80) by the Heaviside function gives

$S_{p, d}(t, x)=\frac{m_{L}}{A} \frac{\partial H\left(t-t_{s}\right)}{\partial t}$

Substituting $S_{p, d}$ of Eq.(83) in Eq. (20) and Eq. (31) results in

$\frac{\partial\left(c_{w}^{*} A\right)}{\partial t}=\frac{\partial\left(A \cdot J_{w}\right)}{\partial x}-R_{t, p} A+J_{a} W-J_{s} P_{0}+m_{L} \frac{\partial H\left(t-t_{s}\right)}{\partial t}$

Combining the time derivatives gives

$\frac{\partial\left(c_{w}^{*} A\right)-m_{L} \partial H\left(t-t_{s}\right)}{\partial t}=\frac{\partial\left(A \cdot J_{w}\right)}{\partial x}-R_{t, p} A+J_{a} W-J_{S} P_{0}$

\section{A2.4 Continuous point release}

Note that this type of input is currently not implemented in TOXSWA. A discharging tributary and a release from a single discharging drain, adding water with a constant concentration of the substance are examples of continuous point releases. The mass of the substance released per unit of time is $m_{T}$ $\left(\mathrm{kg} \mathrm{d}^{-1}\right)$ and this is ideally mixed over the cross sectional area $A$.

$S_{c, p}(t, x)=\sum_{r=1}^{n} \frac{m_{T}}{A} \xi(t) \delta\left(x-x_{r}\right)$

with:

$m_{\mathrm{T}} \quad=$ mass of substance $\left(\mathrm{kg} \mathrm{d}^{-1}\right)$

$r \quad=$ number of point type inputs (total $n$ inputs)

In Eq. (86) $\xi(\mathrm{t})$ is the release time function (dimension 1 ) defined by:

$\xi(t)=0$ for $t<t_{r s}$ or $t>t_{r s}$

$\xi(t)=1$ for $t_{r s} \leq t \leq t_{r e}$

with

$t_{\mathrm{rs}} \quad=$ time at which the continuous release at location $x_{\mathrm{rs}}$ starts (d)

$t_{\mathrm{re}} \quad=$ time at which the continuous release at location $x_{\mathrm{re}}$ ends (d)

\section{A2.5 Continuous distributed release}

Releases via drainage and runoff are examples of continuous distributed releases into the water layer. Release via erosion is an example of a continuous distributed release into the sediment. 
For the water layer the lineic mass of substance released per unit of time is $m_{L T}\left(\mathrm{~kg} \mathrm{~m}^{-1} \mathrm{~d}^{-1}\right.$, e.g. calculated as release per unit of length in the flow direction).

$S_{c, d}(t, x)=\sum_{r=1}^{n} \frac{m_{L T}}{A} \xi(t)$

with:

$m_{L T} \quad=$ lineic mass of substance $\left(\mathrm{kg} \mathrm{m}^{-1} \mathrm{~d}^{-1}\right)$

For the sediment the lineic mass of substance released per unit of time is $m_{L T}\left(\mathrm{~kg} \mathrm{~m}^{-1} \mathrm{~d}^{-1}\right.$, calculated as release per unit of length in the flow direction).

$S_{c, d}(t, z)=\sum_{r=1}^{n} \frac{m_{L T}}{P_{1 / 2 z_{\text {mix }}} z_{\text {mix }}} \xi(t)$

with

$P_{1 / 2 z m i x}=$ length of wetted perimeter at $z=1 / 2 z_{\text {mix }}$ in sediment $(\mathrm{m})$

$z_{\text {mix }} \quad=$ thickness of top layer of sediment, into which pesticide sorbed to eroded soil is distributed (m) 



\section{Annex 3 Iteration solution of the Freundlich sorption equation}

In case of using the non-linear Freundlich sorption equation, the partitioning of the pesticide depends on the concentration in the liquid phase. Then the concentration in the liquid phase cannot be expressed in an explicit way as a function of the other quantities. The implicit equation has to be solved by iteration. This is needed for sorption to suspended solids in the water layer and for sorption to the solid phase in the sediment.

\section{Sorption to suspended solids in the water layer}

To approximate the fluxes of the substance in the right-hand term of the conservation equation for the water layer, Eq. (20), a value of the concentration in the liquid phase, $c_{w}$, have to be derived from known values of the total concentration $c_{w} *$, which was given by:

The total pesticide concentration in the water layer, $c_{w}{ }^{*}$, is given by Eq. (22). Combining Eqs. (22), (36) and (38) results in:

$c_{w}^{*}=c_{w}+\frac{m_{m p} P_{0}}{A} K_{m p} c_{w}+m_{s s} K_{F, s s} c_{s s, r}\left(\frac{c_{w}}{c_{s s, r}}\right)^{N_{s s}}$

with:

$c_{\mathrm{w}}{ }^{*}=$ mass concentration of substance in water layer, including substance sorbed to suspended solids and to macrophytes $\left(\mathrm{kg} \mathrm{m}^{-3}\right)$

$c_{\mathrm{w}} \quad=$ mass concentration of substance in the water phase $\left(\mathrm{kg} \mathrm{m}^{-3}\right)$

$m_{\mathrm{mp}} \quad=$ dry weight of macrophytes per area of sediment $\left(\mathrm{kg} \mathrm{m}^{-2}\right)$

$P_{0} \quad=$ length of wetted perimeter at depth $z=0$, via which exchange between water and sediment occurs $(\mathrm{m})$

$A \quad=$ wetted cross sectional area of flow $\left(\mathrm{m}^{2}\right)$

$K_{\mathrm{mp}}=$ distribution coefficient for substance between macrophytes and water, i.e. the slope of the linear sorption isotherm on the mass of dry macrophytes $\left(\mathrm{m}^{3} \mathrm{~kg}^{-1}\right)$

$m_{s s} \quad=$ mass concentration of suspended solids in the water layer $\left(\mathrm{kg} \mathrm{m}^{-3}\right)$

$K_{\mathrm{F}, \mathrm{ss}} \quad=$ Freundlich coefficient for sorption to suspended solids $\left(\mathrm{m}^{3} \mathrm{~kg}^{-1}\right)$

$c_{\mathrm{ss}, \mathrm{r}}=$ reference concentration in the liquid phase for sorption to suspended solids $\left(\mathrm{kg} \mathrm{m}^{-3}\right)$

$N_{\mathrm{ss}} \quad=$ Freundlich exponent for sorption to suspended solids (1)

Eq. (90) shows that it is impossible to derive values of $c_{w}$ from values of $c_{w}^{*}$ in an explicit way. Rearranging Eq. (90) yields an implicit equation in $c_{w}$ :

$c_{w}=\frac{c_{w}^{*}}{1+\frac{m_{m p} P_{0}}{A} K_{m p}+m_{s S} K_{F, s S}\left(\frac{c_{w}}{c_{s s, r}}\right)^{N_{s s}-1}}$

In Step 1 of the iteration, the 'old' value of $c_{w}$ is introduced at the right hand side of Eq. (91), and known values for the other variables of this right-hand term (including $c_{\mathrm{w}}{ }^{*}$ ). Then, a first estimate for $c_{w}$ on the left hand side of the equation is obtained, the 'new' value of $c_{w}$. In Step 2, this 'new' value for $c_{w}$ is filled in at the right hand side of Eq. (91) to replace the 'old' value of $c_{w}$. The iteration is continued until the difference between the 'new' and 'old' values of $c_{w}$ becomes very small. The last $c_{w}$ value calculated is the solution of the implicit Eq. (91). 


\section{Sorption to solid phase in sediment}

To approximate the fluxes of the substance in the right-hand term of the conservation equation for the sediment, Eq. (26), a value of the concentration in the liquid phase, $\mathrm{Cl}_{1, \mathrm{~s}}$, have to be derived from known values of the total concentration $c_{\mathrm{s}}{ }^{*}$, which was given by:

The total pesticide concentration in sediment, $c_{s}{ }^{*}$, is given by Eq. (28). Combining Eq. (28) and (39) results in:

$c_{S}^{*}=\varepsilon c_{l, s}+\rho_{b} K_{F, S} c_{s, r}\left(\frac{c_{l, s}}{c_{s, r}}\right)^{N_{S}}$

with:

$c_{s}^{*} \quad=$ mass concentration in the sediment $\left(\mathrm{kg} \mathrm{m}^{-3}\right)$

$\varepsilon \quad=$ volume fraction of pore water (1)

$\mathrm{C}_{1, \mathrm{~s}} \quad=$ mass concentration of substance in liquid phase in the sediment $\left(\mathrm{kg} \mathrm{m}^{-3}\right)$

$\rho_{\mathrm{b}} \quad=$ bulk density of dry sediment, i.e. volumic mass of dry sediment material $\left(\mathrm{kg} \mathrm{m}^{-3}\right)$

$K_{\mathrm{F}, \mathrm{S}} \quad=$ Freundlich coefficient for sorption to sediment $\left(\mathrm{m}^{3} \mathrm{~kg}^{-1}\right)$

$c_{s, r} \quad=$ reference concentration in the liquid phase for sorption to sediment $\left(\mathrm{kg} \mathrm{m}^{-3}\right)$

$N_{\mathrm{s}} \quad=$ Freundlich exponent for sorption to sediment (-)

Eq. (92) shows that it is impossible to derive values of $c_{1, s}$ from values of $c_{s}{ }^{*}$ in an explicit way. Rearranging Eq. (92) yields an implicit equation in $c_{1, s}$ :

$c_{l, s}=\frac{c_{s}^{*}}{\varepsilon+\rho_{b} K_{F, s}\left(\frac{c_{l, s}}{c_{s, r}}\right)^{N_{s}-1}}$

To determine the concentration in the liquid phase, $c_{1, s}$, the iteration procedure described for suspended solids in the water layer is used with Eq. (93). The last $c_{1,5}$ value calculated is the solution of the implicit Eq. (93). 



\section{Published documents in the Technical reports series of the Statutory Research Tasks Unit for}

Nature \& the Environment.

WOt-technical reports are available from the secretary's office, T 0317 - 4854 71; E info.wnm@wur.nl

Reports can also be downloaded from www.wur.nl/wotnatuurenmilieu

1 Arets, E.J.M.M., K.W. van der Hoek, H. Kramer, P.J. Kuikman \& J.-P. Lesschen (2013). Greenhouse gas reporting of the LULUCF sector for the UNFCCC and Kyoto Protocol. Background to the Dutch NIR 2013.

2 Kleunen, A. van, M. van Roomen, L. van den Bremer, A.J.J. Lemaire, J-W. Vergeer \& E. van Winden (2014). Ecologische gegevens van vogels voor Standaard Gegevensformulieren Vogelrichtlijngebieden.

3 Bruggen, C. van, A. Bannink, C.M. Groenestein, B.J. de Haan, J.F.M. Huijsmans, H.H. Luesink, S.M. van der Sluis, G.L. Velthof \& J. Vonk (2014). Emissies naar lucht uit de landbouw in 2012. Berekeningen van ammoniak, stikstofoxide, lachgas, methaan en fijn stof met het model NEMA

4 Verburg, R.W., T. Selnes \& M.J. Bogaardt (2014). Van denken naar doen; ecosysteemdiensten in de praktijk. Case studies uit Nederland, Vlaanderen en het Verenigd Koninkrijk.

5 Velthof, G.L. \& O. Oenema (2014). Commissie van Deskundigen Meststoffenwet. Taken en werkwijze; versie 2014

6 Berg, J. van den, V.J. Ingram, L.O. Judge \& E.J.M.M Arets (2014). Integrating ecosystem services into tropical commodity chains- cocoa, soy and palm oil; Dutch policy options from an innovation system approach

7 Knegt, B. de, T. van der Meij, S. Hennekens, J.A.M. Janssen \& W. Wamelink (2014). Status en trend van structuur- en functiekenmerken van Natura 2000habitattypen op basis van het Landelijke Meetnet Flora (LMF) en de Landelijke Vegetatie Databank (LVD). Achtergronddocument voor de Artikel 17-rapportage.

8 Janssen, J.A.M., E.J. Weeda, P.C. Schipper, R.J. Bijlsma, J.H.J. Schaminée, G.H.P. Arts, C.M. Deerenberg, O.G. Bos \& R.G. Jak (2014). Habitattypen in Natura 2000gebieden. Beoordeling van oppervlakte representativiteit en behoudsstatus in de Standard Data Forms.

9 Ottburg, F.G.W.A., J.A.M. Janssen (2014). Habitatrichtlijnsoorten in Natura 2000gebieden. Beoordeling van populatie, leefgebied en isolatie in de Standard Data Forms (SDFs)

10 Arets, E.J.M.M. \& F.R. Veeneklaas (2014). Costs and benefits of a more sustainable production of tropical timber.

11 Vader, J. \& M.J. Bogaardt (2014). Natuurverkenning 2 jaar later; Over gebruik en doorwerking van Natuurverkenning 2010-2040.

12 Smits, M.J.W. \& C.M. van der Heide (2014). Hoe en waarom bedrijven bijdragen aan behoud van ecosysteemdiensten; en hoe de overheid dergelijke bijdragen kan stimuleren.

13 Knegt, B. de (ed.) (2014). Graadmeter Diensten van Natuur; Vraag, aanbod, gebruik en trend van goederen en diensten uit ecosystemen in Nederland.

14 Beltman, W.H.J., M.M.S. Ter Horst, P.I. Adriaanse, A. de Jong \& J. Deneer (2014). FOCUS_TOXSWA manual 4.4.2; User's Guide version 4
15 Adriaanse, P.I., W.H.J. Beltman \& F. Van den Berg (2014). Metabolite formation in water and in sediment in the TOXSWA model. Theory and procedure for the upstream catchment of FOCUS streams.

16 Groenestein, K., C. van Bruggen en H. Luesink (2014). Harmonisatie diercategorieën

17 Kistenkas, F.H. (2014). Juridische aspecten van gebiedsgericht natuurbeleid (Natura 2000)

18 Koeijer, T.J. de, H.H. Luesink \& C.H.G. Daatselaar (2014). Synthese monitoring mestmarkt 2006 - 2012.

19 Schmidt, A.M., A. van Kleunen, L. Soldaat \& R. Bink (2014). Rapportages op grond van de Europese Vogelrichtlijn en Habitatrichtlijn. Evaluatie rapportageperiode 2007-2012 en aanbevelingen voor de periode 2013-2018

20 Fey F.E., N.M.A.J. Dankers, A. Meijboom, P.W. van Leeuwen, M. de Jong, E.M. Dijkman \& J.S.M. Cremer (2014). Ontwikkeling van enkele mosselbanken in de Nederlandse Waddenzee, situatie 2013.

21 Hendriks, C.M.A., D.A. Kamphorst en R.A.M. Schrijver (2014). Motieven van actoren voor verdere verduurzaming in de houtketen.

22 Selnes, T.A. and D.A. Kamphorst (2014). International governance of biodiversity; searching for renewal

23 Dirkx, G.H.P, E. den Belder, I.M. Bouwma, A.L. Gerritsen, C.M.A. Hendriks, D.J. van der Hoek, M. van Oorschot \& B.I. de Vos (2014). Achtergrondrapport bij beleidsstudie Natuurlijk kapitaal: toestand, trends en perspectief; Verantwoording casestudies

24 Wamelink, G.W.W., M. Van Adrichem, R. Jochem \& R.M.A. Wegman (2014). Aanpassing van het Model for Nature Policy (MNP) aan de typologie van het Subsidiestelsel Natuur en Landschap (SNL); Fase 1

25 Vos, C.C., C.J. Grashof-Bokdam \& P.F.M. Opdam (2014). Biodiversity and ecosystem services: does species diversity enhance effectiveness and reliability? A systematic literature review.

26 Arets, E.J.M.M., G.M. Hengeveld, J.P. Lesschen, H. Kramer, P.J. Kuikman \& J.W.H. van der Kolk (2014). Greenhouse gas reporting of the LULUCF sector for the UNFCCC and Kyoto Protocol. Background to the Dutch NIR 2014.

27 Roller, J.A. te, F. van den Berg, P.I. Adriaanse, A. de Jong \& W.H.J. Beltman (2014). Surface WAter Scenario Help (SWASH) version 5.3. technical description

28 Schuiling, C., A.M. Schmidt \& M. Boss (2014). Beschermde gebiedenregister; Technische documentatie

29 Goossen, C.M., M.A. Kiers (2015). Mass mapping; State of the art en nieuwe ideeën om bezoekersaantallen in natuurgebieden te meten

30 Hennekens, S.M, M. Boss en A.M. Schmidt (2014). Landelijke Vegetatie Databank; Technische documentatie 
31 Bijlsma, R.J., A. van Kleunen \& R. Pouwels (2014) Structuur- en functiekenmerken van leefgebieden van Vogelrichtlijn- en Habitatrichtlijnsoorten; Een concept en bouwstenen om leefgebieden op landelijk niveau en gebiedsniveau te beoordelen

32 Commissie Deskundigen Meststoffenwet (2015). Nut en risico's van covergisting. Syntheserapport.

33 Bijlsma, R.J. \& J.A.M. Janssen (2014). Structuur en functie van habitattypen; Onderdeel van de documentatie van de Habitatrichtlijn artikel $17-$ rapportage 2013

34 Fey F.E., N.M.J.A. Dankers, A. Meijboom, P.W. van Leeuwen, J. Cuperus, B.E. van der Weide, M. de Jong, E.M. Dijkman \& J.S.M. Cremer (2014). Ecologische ontwikkeling binnen een voor menselijke activiteiten gesloten gebied in de Nederlandse Waddenzee; Tussenrapportage achtste jaar na sluiting (najaar 2013).

35 Kuindersma, W., F.G. Boonstra, R.A. Arnouts, R. Folkert, R.J. Fontein, A. van Hinsberg \& D.A. Kamphorst (2015). Vernieuwingen in het provinciaal natuurbeleid; Vooronderzoek voor de evaluatie van het Natuurpact.

36 Berg van den, F., W.H.J. Beltman, P.I. Adriaanse, A. de Jong \& J.A. te Roller (2015). SWASH Manual 5.3. User's Guide version 5

37 Brouwer, F.M., A.B. Smit \& R.W. Verburg (2015). Economische prikkels voor vergroening in de landbouw

38 Verburg, R.W., R. Michels, L.F. Puister (2015). Aanpassing Instrumentarium Kosten Natuurbeleid (IKN) aan de typologie van het Subsidiestelsel Natuur en Landschap (SNL)

39 Commissie Deskundigen Meststoffenwet (2015). Actualisering methodiek en protocol om de fosfaattoestand van de bodem vast te stellen

40 Gies, T.J.A., J. van Os, R.A. Smidt, H.S.D. Naeff \& E.C. Vos (2015). Geografisch Informatiesysteem Agrarische Bedrijven (GIAB); Gebruikershandleiding 2010.

41 Kramer, H., J. Clement (2015). Basiskaart Natuur 2013. Een landsdekkend basisbestand voor de terrestrische natuur in Nederland

42 Kamphorst, D.A., T.A. Selnes, W. Nieuwenhuizen (2015). Vermaatschappelijking van natuurbeleid. Een verkennend onderzoek bij drie provincies

43 Commissie Deskundige Meststoffenwet (2015). Advies 'Mestverwerkingspercentages 2016'

44 Meeuwsen, H.A.M. \& R. Jochem (2015). Openheid van het landschap; Berekeningen met het model ViewScape

45 Groenestein, C.M., J. de Wit, C. van Bruggen \& O. Oenema (2015). Stikstof- en fosfaatexcretie van gangbaar en biologisch gehouden landbouwhuisdieren. Herziening excretieforfaits Meststoffenwet 2015

46 Bruggen, C. van, A. Bannink, C.M. Groenestein, J.F.M. Huijsmans, H.H. Luesink, S.M. van der Sluis, G.L. Velthof \& J. Vonk (2015). Emissies naar lucht uit de landbouw, 1990-2013. Berekeningen van ammoniak, stikstofoxide, lachgas, methaan en fijn stof met het model NEMA.

47 Boonstra, F.G. \& A.L. Gerritsen (2016). Systeemverantwoordelijkheid in het natuurbeleid; Input voor agendavorming van de Balans van de Leefomgeving 2014
48 Overbeek, M.M.M., M-J. Bogaardt \& J.C. Dagevos (2015). Intermediairs die bijdragen van burgers en bedrijven aan natuur en landschap mobiliseren.

49 Os, J. van, R.A.M. Schrijver \& M.E.A. Broekmeyer (2015). Kan het Natuurbeleid tegen een stootje? Enkele botsproeven van de herijkte Ecologische Hoofdstructuur.

50 Hennekens, S.M., J.M. Hendriks, W.A. Ozinga, J.H.J. Schaminée \& L. Santini (2015). BioScore 2 - Plants \& Mammals. Background and pre-processing of distribution data

51 Koffijberg K., P. de Boer, F. Hustings, A. van Kleunen, K. Oosterbeek \& J.S.M. Cremer (2015). Broedsucces van kustbroedvogels in de Waddenzee in 2011-2013.

52 Arets, E.J.M.M., J.W.H van der Kolk, G.M. Hengeveld, J.P. Lesschen, H. Kramer, P.J. Kuikman \& M.J. Schelhaas (2015). Greenhouse gas reporting of the LULUCF sector in the Netherlands. Methodological background.

53 Vonk, J., A. Bannink, C. van Bruggen, C.M. Groenestein, J.F.M. Huijsmans, J.W.H. van der Kolk, H.H. Luesink, S.V. Oude Voshaar, S.M. van der Sluis \& G.L. Velthof (2016). Methodology for estimating emissions from agriculture in the Netherlands. Calculations of $\mathrm{CH}_{4}$ $\mathrm{NH}_{3}, \mathrm{~N}_{2} \mathrm{O}, \mathrm{NO}_{x}, \mathrm{PM}_{10}, \mathrm{PM}_{2.5}$ and $\mathrm{CO}_{2}$ with the National Emission Model for Agriculture (NEMA)

54 Groenestein, K. \& J. Mosquera (2015). Evaluatie van methaanemissieberekeningen en -metingen in de veehouderij.

55 Schmidt, A.M. \& A.S. Adams (2015). Documentatie Habitatrichtlijn-rapportage artikel 17, 2007-2012

56 Schippers, P., A.M. Schmidt, A.L. van Kleunen \& L. van den Bremer (2015). Standard Data Form Natura 2000; bepaling van de belangrijkste drukfactoren in Natura 2000-gebieden.

57 Fey F.E., N.M.A.J. Dankers, A. Meijboom, C. Sonneveld J.P. Verdaat, A.G. Bakker, E.M. Dijkman \& J.S.M. Cremer (2015). Ontwikkeling van enkele mosselbanken in de Nederlandse Waddenzee, situatie 2014

58 Blaeij, A.T. de, R. Michels, R.W. Verburg \& W.H.G.J. Hennen (2015). Recreatiemodule in Instrumentarium Kosten Natuurbeleid (IKN); Bepaling van de recreatiekosten

59 Bakker, E. de, H. Dagevos, R.J. Fontein \& H.J. Agricola (2015). De potentie van co-creatie voor natuurbeleid. Een conceptuele en empirische verkenning.

60 Bouwma, I.M., A.L. Gerritsen, D.A. Kamphorst \& F.H Kistenkas (2015). Policy instruments and modes of governance in environmental policies of the European Union; Past, present and future

61 Berg, F. van den, A. Tiktak, J.J.T.I. Boesten \& A.M.A van der Linden (2016). PEARL model for pesticide behaviour and emissions in soil-plant systems; Description of processes

62 Kuiters, A.T., G.A. de Groot, D.R. Lammertsma, H.A.H. Jansman \& J. Bovenschen (2016). Genetische monitoring van de Nederlandse otterpopulatie, Ontwikkeling van populatieomvang en genetische status 2014/2015

63 Smits, M.J.W., C.M. van der Heide, H. Dagevos, T. Selnes \& C.M. Goossen (2016). Natuurinclusief ondernemen: van koplopers naar mainstreaming? 
64 Pouwels, P. , M. van Eupen, M.H.C. van Adrichem, B. de Knegt \& J.G.M. van der Greft (2016).

MetaNatuurplanner v2.0. Status $A$

65 Broekmeyer, M.E.A. \& M.E. Sanders (2016).

Natuurwetgeving en het omgevingsrecht. Achtergronddocument bij Balans van de Leefomgeving, 2014

66 Os, J. van, J. H.S.D. Naeff \& L.J.J. Jeurissen (2016).Geografisch informatiesysteem voor de emissieregistratie van landbouwbedrijven; GIABplusbestand 2013 - Status $A$

67 Ingram, V.J., L.O. Judge, M. Luskova, S. van Berkum \& J. van den Berg (2016). Upscaling sustainability initiatives in international commodity chains; Examples from cocoa, coffee and soy value chains in the Netherlands.

68 Duin van W.E., H. Jongerius, A. Nicolai, J.J. Jongsma, A Hendriks \& C. Sonneveld (2016). Friese en Groninger kwelderwerken: Monitoring en beheer 1960-2014.

69 Ehlert, P.A.I., T.A. van Dijk \& O. Oenema (2016). Opname van struviet als categorie in het Uitvoeringsbes/uit Meststoffenwet. Advies.

70 Ehlert, P.A.I., H.J. van Wijnen, J. Struijs, T.A. van Dijk, L. van Schöll, L.R.M. de Poorter (2016).

Risicobeoordeling van contaminanten in afval- en reststoffen bestemd voor gebruik als covergistingsmateriaal

71 Commissie Deskundigen Meststoffenwet (2016) Protocol beoordeling stoffen Meststoffenwet. Versie 3.2

72 Kramer, H., J. Clement (2016). Basiskaart Natuur 2009. Een landsdekkend basisbestand voor de terrestrische natuur in Nederland

73 Dam, R.I. van, T.J.M. Mattijssen, J. Vader, A.E. Buijs \& J.L.M. Donders (2016). De betekenis van groene zelfgovernance. Analyse van verschillende vormen van dynamiek in de praktijk.

74 Hennekens, S.M., M. Boss \& A.M. Schmidt (2016). Landelijke Vegetatie Databank; Technische documentatie, Status A

75 Knegt, B. de, et al. (2016). Kansenkaarten voor duurzaam benutten van Natuurlijk Kapitaal

76 Commissie Deskundigen Meststoffenwet (2016). Advies 'Mestverwerkingspercentages 2017'

77 W.H.J. Beltman, C. Vink \& A. Poot (2016). Calculation of exposure concentrations for NL standard scenarios by the TOXSWA model; Use of FOCUS_TOXSWA 4.4.3 software for plant protection products and their metabolites in Dutch risk assessment for aquatic ecosystems

78 Koffijberg K., J.S.M. Cremer, P. de Boer, J. Postma \& K Oosterbeek \& J.S.M. Cremer (2016). Broedsucces van kustbroedvogels in de Waddenzee in 2014.

79 Sanders, M.E. G.W.W Wamelink, R.M.A. Wegman \& J. Clement (2016). Voortgang realisatie nationaal natuurbeleid; Technische achtergronden van een aantal indicatoren uit de digitale Balans van de Leefomgeving 2016.

80 Vries, S. de \& I.G. Staritsky (2016). AVANAR 2.0 nader beschreven en toegelicht; Achtergronddocumentatie voor Status $A$.
81 Kuiters, A.T., G.A. de Groot, D.R. Lammertsma, H.A.H. Jansman \& J. Bovenschen (2016). Genetische monitoring van de Nederlandse otterpopulatie; Ontwikkeling van populatieomvang en genetische status 2015/ 2016.

82 Pleijte, M., R. Beunen \& R. During (2016) Rijksprojecten: hét natuurinclusieve werken? Een analyse van relaties tussen rijksprojecten en de Rijksnatuurvisie

83 Smits, M.J.W. en E.J. Bos (2016). Het stimuleren van ondernemen met natuur: handelingsopties voor de overheid

84 Horst, M.M.S. ter, W.H.J. Beltman \& F. van den Berg (2016). The TOXSWA model version 3.3 for pesticide behaviour in small surface waters; Description of processes. 



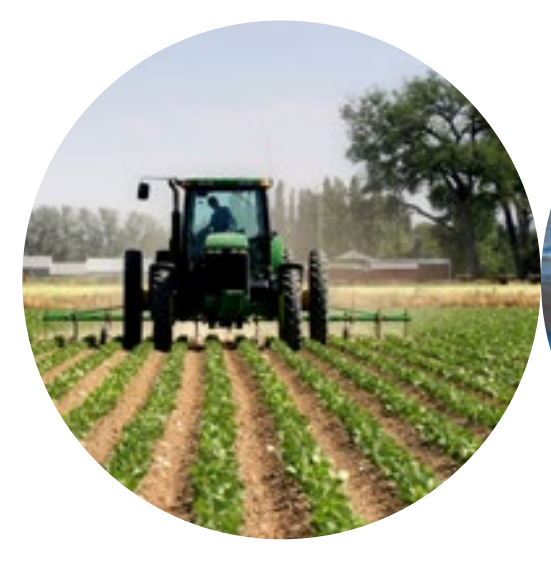

Theme Agri-Environment Wettelijke Onderzoekstaken Natuur \& Milieu

P.O. Box 47

6700 AA Wageningen

T (0317) 485471

E info.wnm@wur.nl

ISSN 2352-2739

www.wur.nl/wotnatuurenmilieu

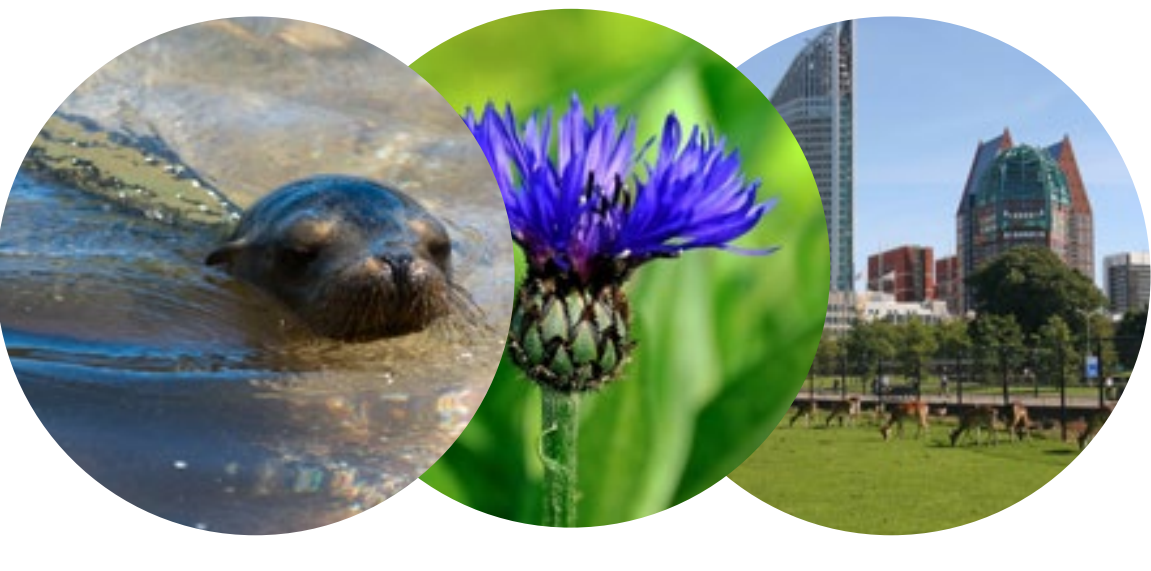

The mission of Wageningen University and Research is 'To explore the potential of nature to improve the quality of life'. Under the banner Wageningen University \& Research, Wageningen University and the specialised research institutes of the Wageningen Research Foundation have joined forces in contributing to inding solutions to important questions in the domain of healthy food and living environment. With its roughly 30 branches, 5,000 employees and 10,000 students, Wageningen University \& Research is one of the leading organisations in its domain. The unique Wageningen approach lies in its integrated approach to issues and the collaboration between different disciplines.

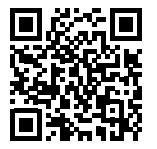

